\title{
Plant Uptake of Explosives from Contaminated Soil at the Joliet Army Ammunition Plant
}

Report No. SFIM-AEC-ET-CR-95014

\author{
April 1995
}

Prepared for:

U.S. Army Environmental Center

Environmental Technology Division

Program Management Branch

Safety Office

Aberdeen Proving Ground, Maryland

Prepared by:

Center for Environmental Restoration Systems

Energy Systems Division

Argonne National Laboratory

Argonne, Illinois

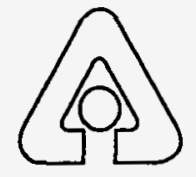




\title{
Plant Uptake of Explosives from Contaminated Soil at the Joliet Army Ammunition Plant
}

\author{
Report No. SFIM-AEC-ET-CR-95014
}

\section{Prepared by:}

\author{
S.D. Zellmer, J.F. Schneider, N.A. Tomczyk
}

Center for Environmental Restoration Systems

Energy Systems Division

Argonne National Laboratory

9700 South Cass Avenue

Argonne, Illinois 60439

and

W.L. Banwart and D. Chen

Department of Agronomy

University of Illinois at Urbana-Champaign

Urbana, Illinois 61801

April 1995

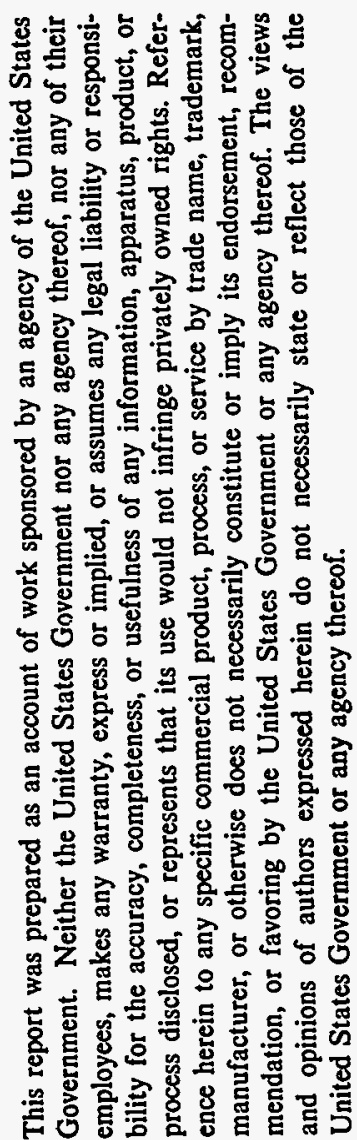

U.S. Army Environmental Center

Submitted to:

Environmental Technology Division

Program Management Branch

Safety Office

Aberdeen Proving Ground, Maryland 


\section{DISCLAIMER}

Portions of this document may be illegible in electronic image products. Images are produced from the best available original document. 


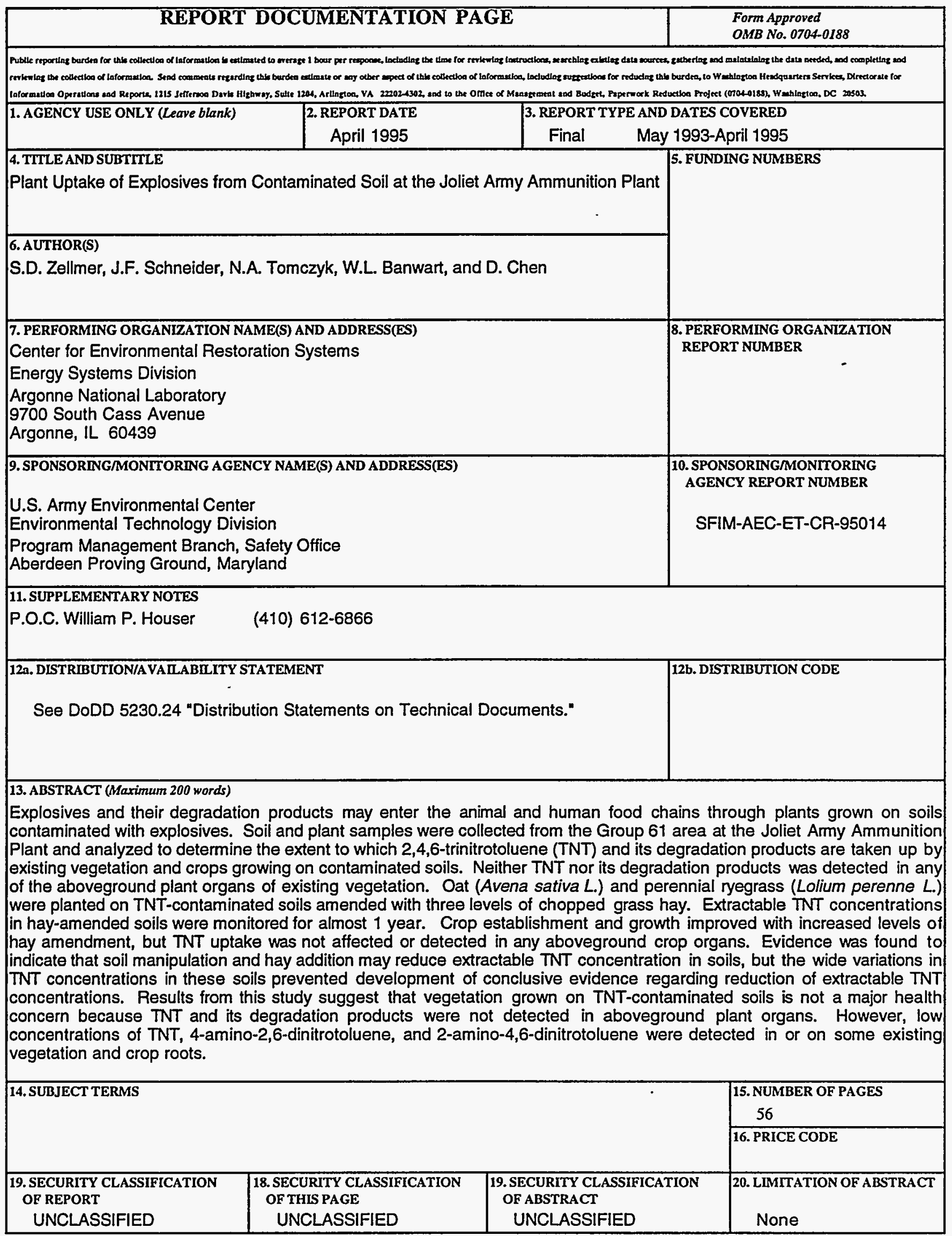

N SN 7540-01-280-5500 Standard Form 298 (Rev. 2-89) 


\section{Contents}

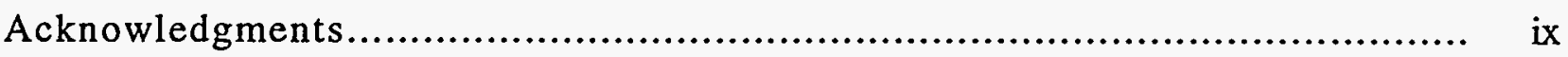

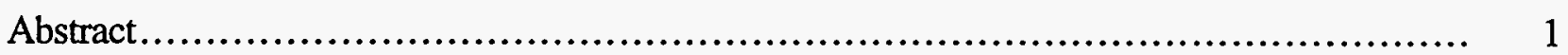

1 Introduction ............................................................................... 1

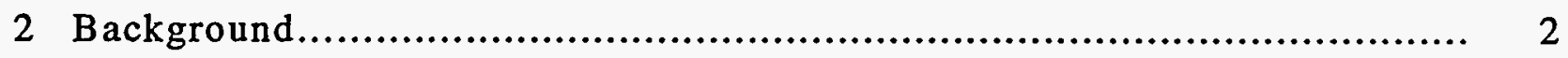

3 Objectives and Approach ........................................................ 3

4 Experimental Site.................................................................. 5

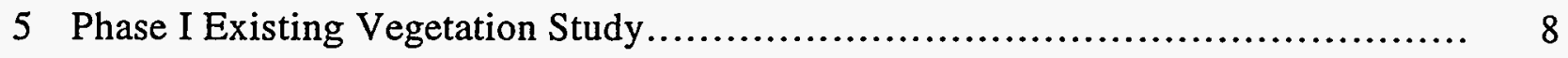

5.1 Sample Collection ......................................................... 8

5.2 Sample Analyses ............................................................ 10

5.3 Results and Discussion ................................................. 11

6 Phase II Crop Uptake Experiment .............................................. 15

6.1 Plot Establishment and Maintenance............................................... 15

6.2 Sample and Data Collection............................................................ 18

6.3 Sample Analyses ............................................................ 19

6.4 Results and Discussion ............................................................... 20

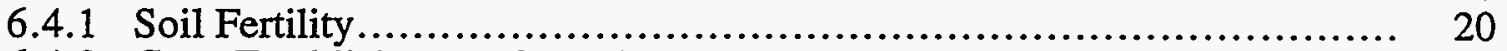

6.4.2 Crop Establishment, Growth, and Development............................ 20

6.4.3 TNT Uptake by Crops ........................................................ 24

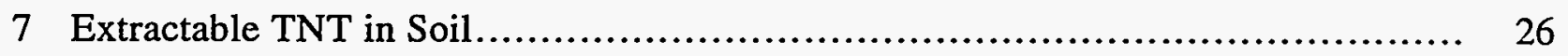

8 Conclusions ............................................................... 32

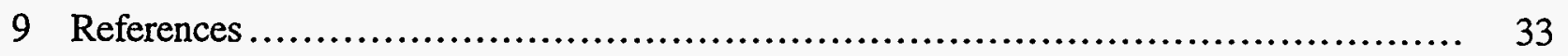

Appendix: Explosive Concentrations in Plot Soils for the Three TNT Areas with Means by Organic Material Addition on Nine Collection Dates

\section{Tables}

1 TNT Concentrations in Soil and Existing Vegetation from the Ridge and Furrow Area, Group 61, Joliet Army Ammunition Plant on .16 August 1993...... 12

2 Toxicity Characteristic Leaching Procedure Results from the Ridge and Furrow Area, Group 61, Joliet Army Ammunition Plant on 16 August 1993 ...... 14

3 Mean Soil Parameters, 0- to 15-cm Depth, from the Ridge and Furrow Area, Group 61, Joliet Army Ammunition Plant on 2 November 1993. 


\section{Tables (Cont.)}

4 Concentration of TNT and its Degradation Products in Oat Roots from the Ridge and Furrow Area, Group 61, Joliet Army Ammunition Plant on 17 July 1994

5 Extractable TNT Concentrations in Soil from the High-TNT Area on Eight Collection Dates

6 Extractable TNT Concentrations in Soil from the Intermediate-TNT Area on Eight Collection Dates.

A.1 Explosive Concentrations in Plot Soils for the High-TNT Area with Means by Organic Material Addition on 15 October 1993, before Organic Material Additions Were Made

A.2 Explosive Concentrations in Plot Soils for the Intermediate-TNT Area with Means by Organic Material Addition on 15 October 1993, before Organic Material Additions Were Made.

A.3 Explosive Concentrations in Plot Soils for the Zero-TNT Area with Means by Organic Material Addition on 15 October 1993, before Organic Material Additions Were Made.

A.4 Explosive Concentrations in Plot Soils for the High-TNT Area with Means by Organic Material Addition on 28 October 1993, Immediately Following Addition of Organic Material

A.5 Explosive Concentrations in Plot Soils for the Intermediate-TNT Area with Means by Organic Material Addition on 28 October 1993, Immediately Following Addition of Organic Material

A.6 Explosive Concentrations in Plot Soils for the Zero-TNT Area with Means by Organic Material Addition on 28 October 1993, Immediately Following Addition of Organic Material

A.7 Explosive Concentrations in Plot Soils for the High-TNT Area with Means by Organic Material Addition on 10 December 1993, 43 Days After Addition of Organic Material

A.8 Explosive Concentrations in Plot Soils for the Intermediate-TNT Area with Means by Organic Material Addition on 10 December 1993, 43 Days After Addition of Organic Material

A.9 Explosive Concentrations in Plot Soils for the High-TNT Area with Means by Organic Material Addition on 17 February 1994, 112 Days After Addition of Organic Material

A.10 Explosive Concentrations in Plot Soils for the Intermediate-TNT Area with Means by Organic Material Addition on 17 February 1994, 112 Days After Addition of Organic Material. 


\section{Tables (Cont.)}

A.11 Explosive Concentrations in Plot Soils for the High-TNT Area with Means by Organic Material Addition on 22 March 1994, 145 Days After Addition of Organic Material

A.12 Explosive Concentrations in Plot Soils for the Intermediate-TNT Area with Means by Organic Material Addition on 22 March 1994, 145 Days After Addition of Organic Material.

A.13 Explosive Concentrations in Plot Soils for the High-TNT Area with Means by Organic Material Addition on 26 April 1994, 180 Days After Addition of Organic Material

A.14 Explosive Concentrations in Plot Soils for the Intermediate-TNT Area with Means by Organic Material Addition on 26 April 1994, 180 Days After Addition of Organic Material

A.15 Explosive Concentrations in Plot Soils for the High-TNT Area with Means by Organic Material Addition on 7 June 1994, 222 Days

After Addition of Organic Material

A.16 Explosive Concentrations in Plot Soils for the Intermediate-TNT Area with Means by Organic Material Addition on 7 June 1994, 222 Days After Addition of Organic Material

A.17 Explosive Concentrations in Plot Soils for the High-TNT Area with Means by Organic Material Addition on 19 July 1994, 264 Days After Addition of Organic Material

A.18 Explosive Concentrations in Plot Soils for the Intermediate-TNT Area with Means by Organic Material Addition on 19 July 1994, 264 Days After Addition of Organic Material

A.19 Explosive Concentrations in Plot Soils for the High-TNT Area with Means by Organic Material Addition on 21 September 1994, 328 Days After Addition of Organic Material.

A.20 Explosive Concentrations in Plot Soils for the Intermediate-TNT Area with Means by Organic Material Addition on 21 September 1994, 328 Days After Addition of Organic Material

\section{Figures}

1 Location of Group 61 at the Joliet Army Ammunition Plant........................

2 Group 61 at the Joliet Army Ammunition Plant .................................. 6

3 Existing Vegetation Sampling Locations in the Ridge and Furrow Area of Group 61, Joliet Army Ammunition Plant. 


\section{Figures (Cont.)}

4 Toxicity Characteristic Leaching Procedure Sampling Locations in the Ridge and Furrow Area, Group 61, Joliet Army Ammunition Plant............. 9

5 TNT Area Locations at Group 61, Joliet Army Ammunition Plant.............. 16

6 Plot Layout for the High-TNT Area at Group 61, Joliet Army Ammunition Plant................................................................. 17

7 Normal and Actual Precipitation in the Group 61 Area at the Joliet Army Ammunition Plant during the Crop Study

8 Relationship between Time and Mean Extractable TNT Concentrations for Plot 20

9 Relationship between Time and Mean Extractable TNT Concentrations for Three Hay Addition Levels in the High-TNT Area........................ 30

10 Relationship between Time and Mean Extractable TNT Concentrations for Three Hay Addition Levels in the Intermediate-TNT Area. 


\section{Acknowledgments}

The authors appreciate the assistance of R.R. Hinchman and J.R. Rastorfer of the Center for Environmental Restoration Systems at Argonne National Laboratory in field identification and laboratory verification of plant species collected during the existing vegetation phase of this study. The authors also express their gratitude to A.M. Holz, Land Manager at Joliet Army Ammunition Plant, for his support and assistance during the field operations portion of this study.

Financial support for this investigation was provided by the U.S. Army Environmental Center, Environmental Technology Division, Program Management Division, Safety Office, Aberdeen Proving Ground, Maryland, through U.S. Department of Energy contract W-31-109-Eng-38. W.P. Houser was the Project Manager and his interest in and support of this effort are appreciated. 


\title{
Plant Uptake of Explosives from Contaminated Soil at the Joliet Army Ammunition Plant
}

\author{
by \\ S.D. Zellmer, J.F. Schneider, N.A. Tomczyk, W.L. Banwart, and D. Chen
}

\begin{abstract}
Explosives and their degradation products may enter the animal and human food chains through plants grown on soils contaminated with explosives. Soil and plant samples were collected from the Group 61 area at the Joliet Army Ammunition Plant and analyzed to determine the extent to which 2,4,6-trinitrotoluene (TNT) and its degradation products are taken up by existing vegetation and crops growing on contaminated soils. Neither TNT nor its degradation products was detected in any of the aboveground plant organs of existing vegetation. Oat (Avena sativa $L$.) and perennial ryegrass (Lolium perenne $L$.) were planted on TNT-contaminated soils amended with three levels of chopped grass hay. Extractable TNT concentrations in hay-amended soils were monitored for almost 1 year. Crop establishment and growth improved with increased levels of hay amendment, but TNT uptake was not affected or detected in any aboveground crop organs. Evidence was found to indicate that soil manipulation and hay addition may reduce extractable TNT concentration in soils, but the wide variations in TNT concentrations in these soils prevented development of conclusive evidence regarding reduction of extractable TNT concentrations. Results from this study suggest that vegetation grown on TNT-contaminated soils is not a major health concern because TNT and its degradation products were not detected in aboveground plant organs. However, low concentrations of TNT, 4-amino-2,6-dinitrotoluene, and 2-amino-4,6-dinitrotoluene were detected in or on some existing vegetation and crop roots.
\end{abstract}

\section{Introduction}

Wastes from the production of munitions during and following World War II were disposed of using the best available and acceptable practices for that time. Waste streams were frequently discharged into lagoons or land application areas and solid waste was often burned on the soil surface. These disposal practices resulted in an accumulation of explosive residues in the soils of these areas. Today, these disposal sites are either covered with invading vegetation or remain barren, depending on the type and concentration of explosive wastes. Explosivescontaminated soil from these sites may be transported by wind or water to adjacent areas. A current environmental and human health concern is that explosives and their degradation products may enter animal and human food chains through uptake by plants growing on explosivescontaminated soils. 


\section{Background}

Published information on the uptake of 2,4,6-trinitrotoluene (TNT) by plants is limited to results from hydroponic and greenhouse investigations. Palazzo and Leggett (1986) reported uptake of TNT by yellow nutsedge (Cyperus esculentus $L$.) from hydroponic solutions containing TNT at 5 to $20 \mathrm{mg} \mathrm{L}^{-1}$. Study results revealed TNT and its degradation products, 4-amino-2,6-dinitrotoluene (4A-DNT) and 2-amino-4,6-dinitrotoluene (2A-DNT), throughout the plants. By increasing TNT levels, researchers increased concentrations and quantities of all three compounds in the plant organs. Folsom et al. (1988) also studied TNT uptake by yellow nutsedge from soil amended with TNT and reported that there was little indication that TNT was taken up by plants. Pennington (1988) also reported little or no evidence of TNT uptake by yellow nutsedge using ${ }^{14} \mathrm{C}$ labeled TNT. Results from another greenhouse study (Banwart and Balbach 1988, unpublished data) indicated that crops - corn (Zea mays L.), sorghum $\times$ sudangrass [Sorghum bicolor (L.) Moench. $\times$ S. sudanense (L.) Moench.], alfalfa (Medicago sativa L.), and wheat (Triticum aestivum L.) - grown in TNT hydroponic solutions and spiked soil contained aminodinitrotoluene (A-DNT) isomers in their roots, but that there was no evidence of TNT in its parent form in the plant shoots.

Banwart and Hassett (1990) studied the effects of organic residue additions to the soil on plant tolerance and extractable TNT from TNT-contaminated soil. Initial TNT levels in the soil were 1000 and $2000 \mathrm{mg} \mathrm{kg}^{-1}$; species tested were perennial ryegrass, sorghum $\times$ sudangrass, and alfalfa. Little or no crop growth occurred on unamended soil, but growth and dry matter production were dramatically improved with the addition of $5 \%$ (by weight) ground wheat straw. The extractable TNT concentration in soil originally containing $2000 \mathrm{mg} \mathrm{kg}^{-1}$ TNT that was amended with wheat straw was less than $2 \%$ of the initial value after 90 days of crop growth.

Cataldo et al. (1993) also studied the fate and degradation products of TNT in soils and in three plant species: wheat, 'Blando' brome (Bromus mollis L.), and bush beans (Phaseolus vulgaris $\mathrm{L}$.). Plants were grown for 60 days in explosives-amended soil. About $70 \%$ of the TNT underwent transformation to A-DNT isomers and unknown chemical species. Uptake of TNT in its original form was low; TNT residues primarily accumulated in plant roots. The majority of contaminants found in plants grown in TNT-amended soils was in the form of 2A- and 4A-DNT. Both of these compounds were also primarily found in the plant roots. The highest TNT uptake was observed in plants grown in the soil with the lowest organic matter content. The nonextractable fraction of TNT increased more rapidly and to higher levels in soil with higher organic content, compared with soils containing lower levels of organic matter.

Results from previous investigations indicate varied uptake of TNT and its degradation products by plants grown under greenhouse and hydroponic conditions. The results also reveal plant tolerance to TNT contamination and suggest that the concentration of extractable TNT in soils may be influenced by organic material content or organic material additions to the soil. However, no data regarding the uptake of TNT and its degradation products by existing vegetation or agricultural crops grown under field conditions are available. 


\section{Objectives and Approach}

This investigation was conducted to provide the U.S. Army Environmental Center (USAEC) with documentation of the extent to which TNT is taken up by existing vegetation and selected agricultural crops grown on contaminated soil at typical explosives waste disposal sites. Specific objects of this field investigation were to determine the following:

- Uptake of TNT and its degradation products by existing vegetation and crops grown on TNT-contaminated soils,

- Influence of soil organic material amendments on TNT uptake by crops grown on TNT-contaminated soil, and

- Effect of soil organic material amendments on extractable TNT concentrations in TNT-contaminated soil.

This investigation was conducted at the ridge and furrow area (R\&FA) of Group 61 at the Joliet Army Ammunition Plant (JAAP). The R\&FA was contaminated by liquid waste (pink water) from a TNT recovery and shell washout operation conducted from 1945 until the mid1950s. The investigation was completed in two phases. TNT uptake by existing vegetation growing on the R\&FA was determined during Phase I. Phase II involved measuring TNT uptake by two agricultural crops growing on soil amended with organic material and monitoring changes in extractable TNT concentrations in soils amended by adding different levels of organic material.

During Phase I (in August 1993), soil and 32 existing vegetation samples were collected from 15 locations in the R\&FA. Nine species of plants were collected; two or more species were obtained at each location. Soils and plant roots and shoots were analyzed for TNT and its degradation products to determine explosives uptake by existing vegetation.

Phase II started during the fall of 1993 . Three areas containing zero, intermediate, and high levels of soil TNT contamination were chosen and each area was divided into 24 plots. Surface soil in each area was mixed and one of three levels $(0 \%, 1 \%$, and $2 \%$ ) of chopped hay, used as the organic material amendment, was incorporated into the upper $15 \mathrm{~cm}(6 \mathrm{in}$.) of soil in each plot. During March of 1994, the plots were planted with oat or ryegrass. Crop establishment and growth were observed and soil samples periodically collected and analyzed to measure changes in extractable TNT concentrations in the soil. Oat harvest and initial ryegrass samples were collected during July and a second ryegrass collection was made in September. Oat roots, shoots, and grains and ryegrass shoots were analyzed for TNT and its degradation products to assess uptake by each crop.

Information generated during this study can be used to assess the health hazards of TNT and its degradation products entering the food chain through uptake by plants grown on TNTcontaminated soil under typical field conditions. These data can also be used to assess the 
influence of organic material addition on extractable TNT concentrations in soil; addition of organic material may represent a potential remediation method for soils containing low levels of TNT contamination. 


\section{Experimental Site}

JAAP is located approximately $27 \mathrm{~km}$ (17 miles) south of Joliet in the Kankakee and Des Plaines river valleys in Will County, Illinois. JAAP was a government-owned, contractoroperated U.S. Army industrial facility formerly operated by Uniroyal Chemical Company, Inc. It was held in an inactive standby condition until 1993, when closure procedures began. Disposition of the property is now under review because the facility was placed on the National Priorities List in April 1989 and is designated as a federal Superfund site. The facility encompasses 9528 ha (23 544 acres or approximately 36 square miles) of former agricultural land. Currently, 3454 ha ( 8534 acres) are leased to a local farmer for row crop and hay production and 2161 ha (5341 acres) are leased for livestock grazing.

JAAP, constructed in the early 1940s for the production of munitions during World War II, included facilities to manufacture, load, assemble, and package explosives. The facility is divided into two major functional areas (Figure 1): the Manufacturing Area and the Load-AssemblePackage (LAP) Area. The Manufacturing Area, west of U.S. Highway 53, covers 3706 ha (9159 acres). The principal operation in this area was the production of constituent chemicals and explosives. The LAP Area is east of U.S. Highway 53 and covers 5821 ha (14 385 acres). This portion of the site included munitions filling and assembly lines, storage magazines, and

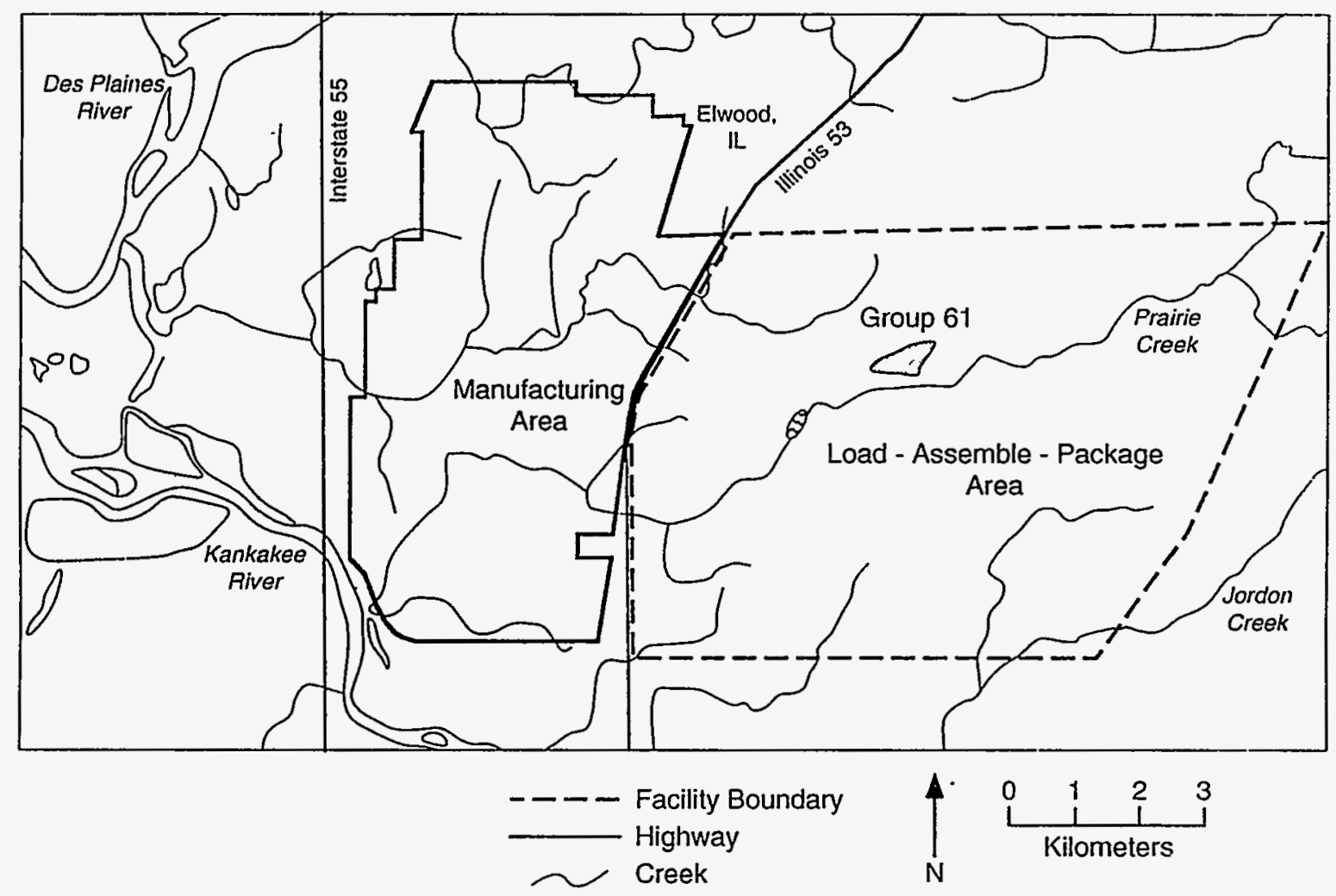

FIGURE 1 Location of Group 61 at the Joliet Army Ammunition Plant 
demilitarization areas. Items such as bombs, projectiles, fuses, and supplementary charges were produced here almost continuously from World War II through the Vietnam conflict until about 1975.

Group 61, which encompasses approximately 32.4 ha (80 acres) in the north-central portion of the LAP Area (Figure 1), was constructed as part of the initial operation of the installation in 1941 to support Word War II efforts. Group 61 facilities were originally used for crystallizing ammonium nitrate, but were later extensively modified and used for shell renovation and TNT recovery until 1945. The facility was reactivated in April 1946 to reclaim TNT from 75-mm, 90-mm, and 3-in. high-explosive shells; the explosives were recycled as part of JAAP operations. Washout of the larger munitions was performed outside the main building on a concrete pad using process water collected in a large concrete sump southeast of the building (Figure 2). Solids that settled out in the sump were sent to the Explosives Burning Grounds for disposal. Overflow water from the sump (pink water) was discharged for disposal by infiltration and evaporation in a 1.6-ha (4-acre) R\&FA south of the sump.

All operations at Group 61 ceased in the mid-1950s and, in the 40 years following closure of the Group 61 facilities, erosion has partially leveled the ridges and filled the furrows. The old furrows, on $2.1-\mathrm{m}$ (7-ft) centers, are still evident, varying in depth from 0 to $20 \mathrm{~cm}(0$ to $8 \mathrm{in}$.),

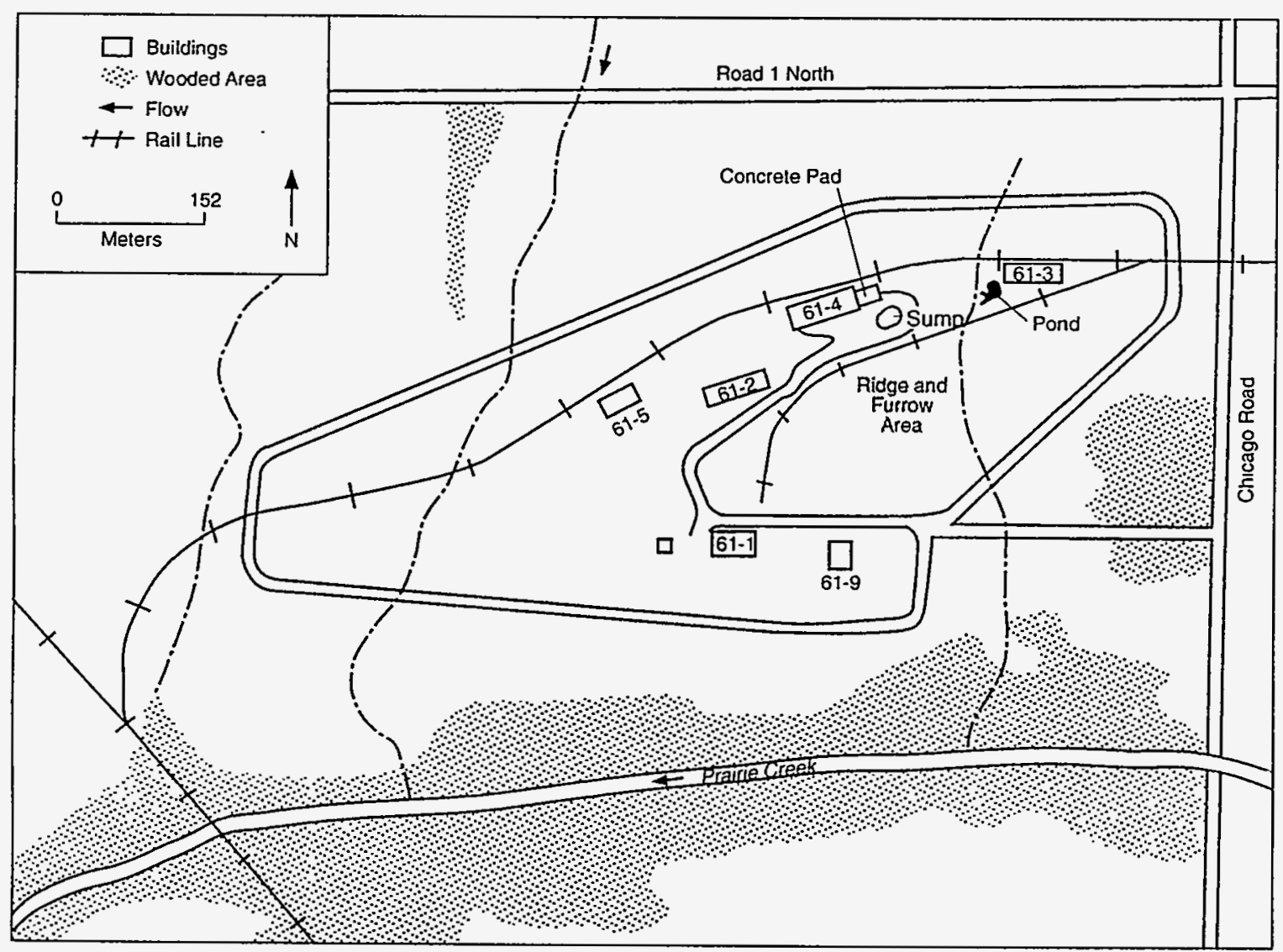

FIGURE 2 Group 61 at the Joliet Army Ammunition Plant 
depending on the degree of erosion. The surface of the western one-third of the R\&FA appears to be glacial till, probably exposed during construction of the R\&FA during the 1940s. Vegetative cover in this part of the R\&FA is sparse and consists mainly of chicory (Cichorium intybus L.) and Queen Anne's lace (Daucus carota L.). The lack of plant cover in this portion of the R\&FA may result from high concentrations of TNT in the soil, low soil fertility, or poor physical condition of the soil.

The surface of the eastern two-thirds of the R\&FA is probably the mixed Elliot silt loam (fine, illitic, mesic Aquic Arigudoll) found on the surrounding landscape. Vegetation on this part of the R\&FA is abundant, consisting mainly of smooth bromegrass (Bromus inermis Leyss.) and a few forb species, mostly common teasel (Dipsacus sylvestris Huds.) and common milkweed (Asclepias syriaca L.). After 40 years, the presence of TNT in the furrow surface soil is still evident by a reddish color and lack of vegetation. 


\section{Phase I Existing Vegetation Study}

\subsection{Sample Collection}

Soil and existing vegetation samples were collected from the R\&FA of Group 61 at JAAP on 16 August 1993 (Figure 3). Information from a previous investigation (Dames \& Moore 1991) and field observations were used to estimate TNT concentrations in the soil at potential sampling locations in the R\&FA. Sampling locations were selected to represent high, intermediate, and low (zero) levels of soil TNT contamination; five locations at each contamination level were selected. Soil samples were collected from the $0-$ to $15-\mathrm{cm}(0-$ to 6 -in.) depth using a $2.5-\mathrm{cm}(1-\mathrm{in}$.) soil probe near selected plants. The samples were placed in plastic bags for transport to the analytical laboratory. The soil probe was cleaned between sampling locations to prevent crosscontamination.

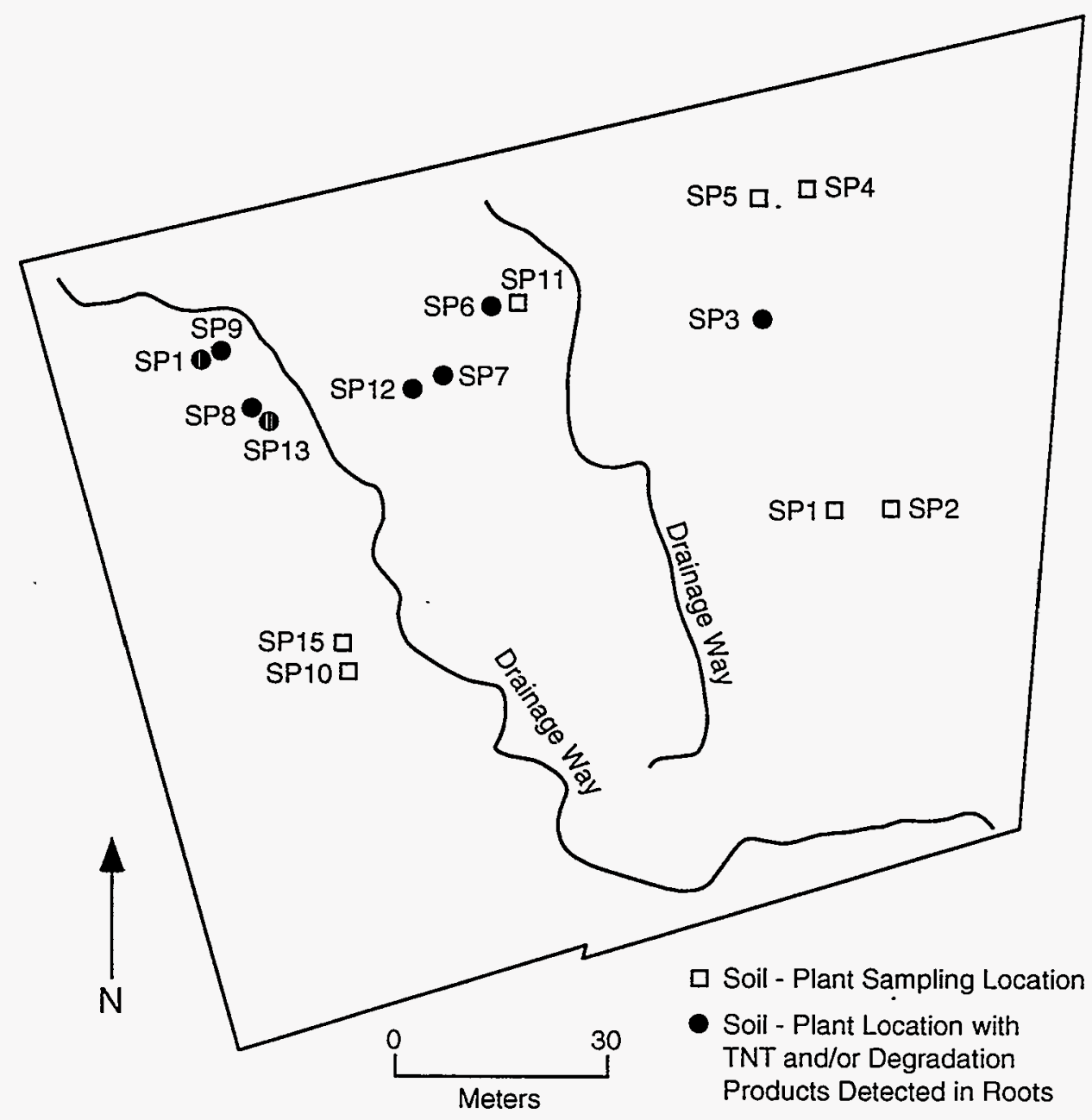

FIGURE 3 Existing Vegetation Sampling Locations in the Ridge and Furrow Area of Group 61, Joliet Army Ammunition Plant 
Two or more plant species were collected from most sampling locations. Selected plants were clipped about $2.5 \mathrm{~cm}$ ( $1 \mathrm{in}$.) above the soil surface; care was taken not to include plant material that had been in direct contact with the soil. Individual plants were identified in the field and bagged separately by species if more than one species was present at a sampling location. A spade was used to loosen the soil around the roots, the plant root mass was extracted, and excess soil was removed before the roots were bagged according to species.

Four additional soil samples were collected to characterize the toxicity of the R\&FA. A random location in each quarter of the R\&FA was selected (Figure 4). Approximately $250 \mathrm{~g}$ of soil from the 0 - to $8-\mathrm{cm}$ (0- to 3-in.) depth was collected and placed in precleaned glass bottles. The bottles were sealed and delivered to a commercial laboratory for analysis.

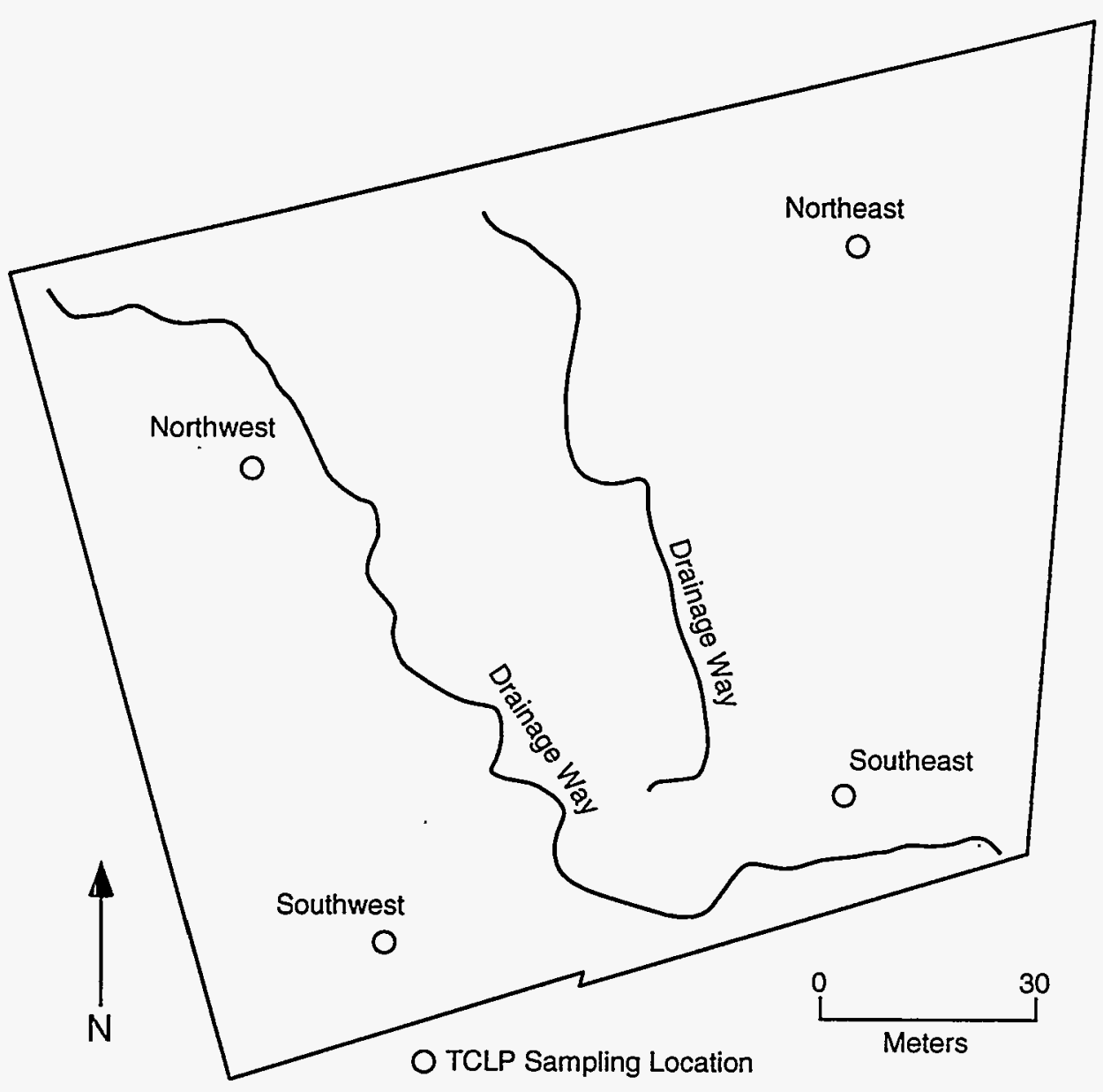

FIGURE 4 Toxicity Characteristic Leaching Procedure Sampling Locations in the Ridge and Furrow Area, Group 61, Joliet Army Ammunition Plant 


\subsection{Sample Analyses}

Soil and plant analyses were performed in a USAEC-approved laboratory at the University of Illinois at Urbana-Champaign. U.S. Environmental Protection Agency (USEPA) SW-846 method 8330 (USEPA 1986) was used to determine the concentrations of explosives and degradation products in soil samples. Soil samples were air dried, ground to pass a $600-\mu \mathrm{m}$ sieve, and homogenized. Prior to analysis, $2.0 \mathrm{~g}$ of the soil was extracted with $10.0 \mathrm{~mL}$ acetonitrile by sonication for 18 hours in a water bath. Samples were analyzed using high-performance liquid chromatography (HPLC) with ultraviolet detection. Compounds targeted by this method included the following: TNT, 1,3,5-trinitro-1,3,5-triazine (RDX), 1,3,5-trinitrobenzene (TNB), 2,4-dinitrotoluene (2,4-DNT), 2,6-dinitrotoluene (2,6-DNT), 4A-DNT, and 2A-DNT. A Beckman System Gold HPLC was used with a Beckman Ultrasphere C-18 $(25 \mathrm{~cm}$ by $4.6 \mathrm{~mm}$, $5 \mu \mathrm{m})$ analytical column. The mobile phase was $58 / 42(\mathrm{v} / \mathrm{v})$, methanol/water.

A method developed by Banwart was used to analyze plant materials for explosives because no approved USEPA analysis method has been developed for plant material. The Banwart method consists of explosive extraction, sample cleanup, and analysis by HPLC with ultraviolet detection using the procedures outlined below.

1. Plant shoots were rinsed with distilled water and the roots were washed in an elutriator to remove soil clinging to the surface. The procedure was used to differentiate explosives taken up by the plant from explosives in soil on the plant organs.

2. The plant material was dried at room temperature, ground to pass a $250-\mu \mathrm{m}$ sieve, and homogenized.

3. One-half gram of ground plant sample was weighed into a 25-mL Corvex tube equipped with a Teflon-lined screw cap.

4. Ten milliliters of dichloromethane was added to each tube and the tubes were placed in a water bath with cooling water and sonicated for 12 to 15 hours.

5. A $2.5-\mathrm{mL}$ aliquot of dichloromethane extract was removed, placed in a glass scintillation vial, and evaporated to dryness by air.

6. Five milliliters of $15 \%$ hexane in dichloromethane was added on the surface of a Florisil solid-phase extraction cartridge to equilibrate the cartridge.

7. The sample residue from Step 5 was dissolved in $1 \mathrm{~mL}$ of $15 \%$ hexane in dichloromethane and added to the surface of the cartridge. 
8. Three milliliters of $15 \%$ hexane in dichloromethane was eluted through the Florisil cartridge to wash out the less polar compounds.

9. Five milliliters of $12 \%$ ethyl acetate in dichloromethane was added to elute the explosive compounds.

10. The collected fraction was evaporated to dryness and the residue was dissolved in $1 \mathrm{~mL}$ of acetonitrile.

11. One milliliter of HPLC-grade water was added and the sample mixture was filtered through a Nalgene $0.2-\mu \mathrm{m}$ filter.

Plant samples were then analyzed using a Beckman System Gold HPLC with a Supelco LC-CN $(25 \mathrm{~cm}$ by $4.6 \mathrm{~mm}, 5 \mu \mathrm{m})$ analytical column. The mobile phase was $17 / 13 / 70(\mathrm{v} / \mathrm{v} / \mathrm{v})$, methanol/tetrahydrofuran/water. Compounds targeted by this method included the following: TNT, RDX, TNB, 2,4-DNT, 2,6-DNT, 4A-DNT, and 2A-DNT. Spiked samples were run to check the validity of the procedures. On plant shoot samples, spike recovery averaged $89 \%$ for TNT, $80 \%$ for RDX, $60 \%$ for $4 \mathrm{~A}-\mathrm{DNT}$, and $90 \%$ for $2 \mathrm{~A}-\mathrm{DNT}$. Spike recovery on the root samples averaged $66 \%$ for TNT, $80 \%$ for RDX, $48 \%$ for $4 \mathrm{~A}-\mathrm{DNT}$, and $84 \%$ for $2 \mathrm{~A}-\mathrm{DNT}$.

The four soil samples collected to characterize the toxicity of the soil in the R\&FA were analyzed by a commercial laboratory (Heritage Laboratories, Inc.) using USEPA TCLP SW-846 method 1311 (USEPA 1986).

\subsection{Results and Discussion}

Table 1 lists the plant species collected and the explosives analytical results of soil and plant samples from the R\&FA at JAAP. Repeated location numbers indicate that two or more plant species were collected from the same location. TNT was the only explosive found in soil at concentrations above detection limits. Soil containing TNT generally also contained TNB, 4A-DNT, and 2A-DNT, but at lower concentrations than the TNT. Plant shoots and roots were analyzed for all targeted compounds, but only TNT, 4A-DNT, and 2A-DNT were found at concentrations above their detection limits. No TNT was detected in the plant shoots, although plants grown in a wide range of soil TNT concentrations were sampled.

TNT, 4A-DNT, and 2A-DNT were detected in 12 of the 32 root samples analyzed. Although root samples were washed to remove surface soil before they were analyzed, there is no way to distinguish between compounds in the root tissue and those remaining on the root surface. Data shown in Table 1 indicate no apparent relationship between soil TNT concentration and the presence of these TNT degradation compounds in root samples - the compounds were found in plant roots from locations containing low (zero), intermediate, and high concentrations of TNT in 
TABLE 1 TNT Concentrations in Soil and Existing Vegetation from the Ridge and Furrow Area, Group 61, Joliet Army Ammunition Plant on 16 August 1993

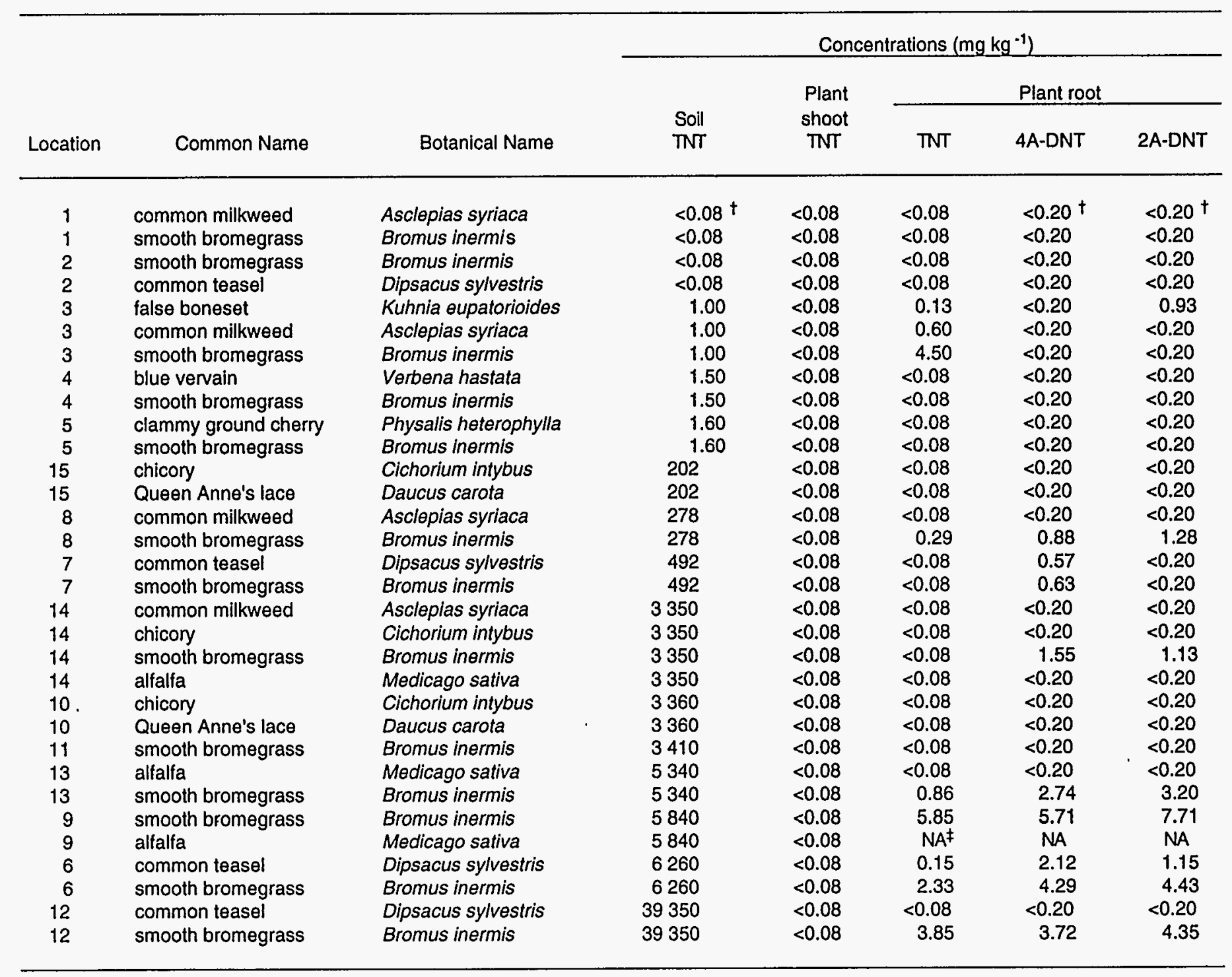

$\dagger$ Detection Limit.

$\mp$ Not analyzed. 
the soil, while roots from other locations with similar soil TNT concentrations did not contain the compounds. There is also no apparent relationship between plant species and the detection of TNT and its degradation products in plant roots. The same plant species were sampled at several locations containing similar TNT soil concentrations and TNT, 4A-DNT, and 2A-DNT were detected in root samples from some locations but were not detected in the same species at other locations.

The presence of TNT, 4A-DNT, and 2A-DNT in plant roots may be related to the type of plant root system. Smooth bromegrass has a fibrous root system while false boneset (Kuhnia eupatorioides $L$.), common milkweed, and common teasel all have a tap root. TNT, 4A-DNT, and 2A-DNT were most often found in bromegrass roots, indicating that these compounds may have been artifacts of ineffective root washing. It is more difficult to remove all the soil containing these compounds from the fibrous root system of bromegrass than from a tap root. Another possibility is that these compounds were removed from the other root samples by the washing operation. This is unlikely because TNT, 4A-DNT, and 2A-DNT are relatively insoluble in water. A third possibility is that TNT is taken up and broken down by some plant roots or degradation occurs in the rhizosphere. Other investigators (Palazzo and Leggett 1986; Cataldo et al. 1993) have also reported the presence of TNT, 4A-DNT, and 2A-DNT in plant roots.

According to material published by the National Institute for Occupational Safety and Health (NIOSH), the lowest published lethal dose of TNT to a human is $28 \mathrm{mg} \mathrm{kg}^{-1}$ of body weight. A report of munitions literature compiled by Sriharan (1992) indicates that the toxicity of 4A-DNT and 2A-DNT varies by animal test species. An average of $25 \mathrm{mg} \mathrm{kg}^{-1} \mathrm{~d}^{-1}$ resulted in symptoms ranging from anemia to death within 22 days. While mice did not show signs of absorbing the compounds, larger rodents and other species (up through primates) did. Some animal species showed partial to full recovery after cessation of the treatment; others had permanent damage such as sterility.

Results of the existing vegetation analyses indicate that neither TNT nor its degradation products were present in the shoots of any plant species sampled at JAAP. No apparent human health hazard is associated with the consumption of plant shoots grown on TNT-contaminated soils. Low concentrations (less than $8.0 \mathrm{mg} \mathrm{kg}^{-1}$ ) of TNT, 4A-DNT, and 2A-DNT were detected in about one third of the root samples, which suggests that some health hazard may be associated with consumption of plant roots grown in TNT-contaminated soils. However, a relatively large volume of roots contaminated at the levels observed would need to be consumed daily to produce a toxic effect.

Table 2 lists the results of the TCLP analyses conducted to characterize the toxicity of the soil in the R\&FA at Group 61. No targeted TCLP compounds were detected in any of the soil samples. These data indicate that the soils in the R\&FA cannot be classified as a toxic waste. 
TABLE 2 Toxicity Characteristic Leaching Procedure Results from the Ridge and Furrow Area, Group 61, Joliet Army Ammunition Plant on 16 August 1993

\begin{tabular}{|c|c|c|c|c|c|}
\hline \multirow[b]{2}{*}{ Analyte } & \multicolumn{4}{|c|}{ Concentration by Sampling Location (mg L $\left.\mathrm{L}^{-1}\right)$} & \multirow{2}{*}{$\begin{array}{c}\text { Detectior } \\
\text { Limit } \\
\left(\mathrm{mg} \mathrm{L}^{-1}\right)\end{array}$} \\
\hline & Northwest & Northeast & Southwest & Southeast & \\
\hline Barium & 3.4 & 1.00 & 0.56 & 0.98 & 0.02 \\
\hline Cadmium & $\mathrm{BDL} t$ & BDL & BDL & BDL & 0.04 \\
\hline Chromium & $\mathrm{BDL}$ & BDL & BDL & BDL & 0.05 \\
\hline Lead & BDL & BDL & $B D L$ & $B D L$ & 0.25 \\
\hline Silver & BDL & $\mathrm{BDL}$ & $\mathrm{BDL}$ & BDL & 0.05 \\
\hline Arsenic & $B D L$ & $\mathrm{BDL}$ & $B D L$ & $B D L$ & 0.01 \\
\hline Selenium & BDL & BDL & $\mathrm{BDL}$ & BDL & 0.01 \\
\hline Mercury & $\mathrm{BDL}$ & BDL & $\mathrm{BDL}$ & BDL & 0.005 \\
\hline 1,4-Dichlorobenzene & $\mathrm{BDL}$ & $\mathrm{BDL}$ & BDL & $\mathrm{BDL}$ & 0.05 \\
\hline 2,4-Dinitrotoluene & BDL & $\mathrm{BDL}$ & $\mathrm{BDL}$ & BDL & 0.05 \\
\hline Hexachlorobenzene & BDL & $B D L$ & BDL & $B D L$ & 0.05 \\
\hline Hexachlorobutadiene & $\mathrm{BDL}$ & $B D L$ & BDL & $\mathrm{BDL}$ & 0.05 \\
\hline Hexachloroethane & $B D L$ & $\mathrm{BDL}$ & $B D L$ & BDL & 0.05 \\
\hline Nitrobenzene & $\mathrm{BDL}$ & $\mathrm{BDL}$ & BDL & $B D L$ & 0.05 \\
\hline Pyridine & BDL & $B D L$ & $B D L$ & $\mathrm{BDL}$ & 0.25 \\
\hline 2-Methyl Phenol & $\mathrm{BDL}$ & $\mathrm{BDL}$ & $B D L$ & BDL & 0.13 \\
\hline 3-Methyl Phenol & $\mathrm{BDL}$ & BDL & BDL & $B D L$ & 0.13 \\
\hline 4-Methyl Phenol & $\mathrm{BDL}$ & $\mathrm{BDL}$ & $\mathrm{BDL}$ & $\mathrm{BDL}$ & 0.13 \\
\hline Pentachlorophenol & $\mathrm{BDL}$ & BDL & $\mathrm{BDL}$ & BDL & 0.25 \\
\hline 2,4,5-Trichlorophenol & $B D L$ & BDL & $B D L$ & BDL & 0.13 \\
\hline 2,4,6-Trichlorophenol & $\mathrm{BDL}$ & $\mathrm{BDL}$ & $\mathrm{BDL}$ & BDL. & 0.13 \\
\hline Benzene & BDL & BDL & BDL & $B D L$ & 0.05 \\
\hline Carbon Tetrachloride & BDL & BDL & $\mathrm{BDL}$ & $B D L$ & 0.05 \\
\hline Chlorobenzene & $\mathrm{BDL}$ & $\mathrm{BDL}$ & BDL & $\mathrm{BDL}$ & 0.05 \\
\hline Chloroform & BDL & BDL & BDL & $B D L$ & 0.05 \\
\hline 1,2-Dichloroethane & $\mathrm{BDL}$ & BDL & BDL & $\mathrm{BDL}$ & 0.05 \\
\hline 1,1-Dichloroethylene & $\mathrm{BDL}$ & BDL & $B D L$ & BDL & 0.05 \\
\hline Methyl Ethyl Ketone & BDL & BDL & $B D L$ & BDL & 0.1 \\
\hline Tetrachloroethylene & $\mathrm{BDL}$ & $\mathrm{BDL}$ & $\mathrm{BDL}$ & $\mathrm{BDL}$ & 0.05 \\
\hline Trichloroethylene & BDL & BDL & $\mathrm{BDL}$ & $\mathrm{BDL}$ & 0.05 \\
\hline Vinyl Chloride & $\mathrm{BDL}$ & $\mathrm{BDL}$ & $B D L$ & $\mathrm{BDL}$ & 0.1 \\
\hline Lindane & $\mathrm{BDL}$ & $\mathrm{BDL}$ & $B D L$ & $\mathrm{BDL}$ & 0.0004 \\
\hline Heptachlor & $\mathrm{BDL}$ & $B D L$ & $\mathrm{BDL}$ & $\mathrm{BDL}$ & 0.0003 \\
\hline Heptachlor Epoxide & BDL & BDL & BDL & BDL & 0.0003 \\
\hline Endrin & BDL & BDL & BDL & $\mathrm{BDL}$ & 0.0005 \\
\hline Methoxychlor & BDL & BDL & $\mathrm{BDL}$ & $\mathrm{BDL}$ & 0.003 \\
\hline Chlordane & BDL & BDL & BDL & $\mathrm{BDL}$ & 0.003 \\
\hline
\end{tabular}

$\dagger$ Below detection limit. 


\section{Phase II Crop Uptake Experiment}

\subsection{Plot Establishment and Maintenance}

Design of the crop uptake experiment required three levels of soil TNT contamination (zero, intermediate, and high), three levels of organic material addition $(0 \%, 1 \%$, and $2 \%)$, and two crops (forage and small grain). Four replications of each treatment (soil contamination level, organic material addition, crop) were included in the study. Changes in extractable TNT concentrations were also monitored on treatment plots with intermediate and high levels of TNT contamination.

In early October of 1993, precipitation and temperature monitoring equipment was installed at the experimental site. The equipment included two rain gauges fitted with electronic devices to record the amount and duration of rainfall events that occurred at the site. The daily maximum, minimum, and 24-hour average air temperature were measured and recorded by using two other electronic devices.

During the fall of 1993, information from a previous investigation (Dames and Moore 1991) and results from soil analyses of samples collected in the R\&FA were used to select locations for three $16-\mathrm{m}$ by $24-\mathrm{m}(52.5-\mathrm{ft}$ by $78.7-\mathrm{ft})$ areas in the Group 61 area at JAAP. Highand intermediate-TNT-contaminated areas were located in the R\&FA. The zero contamination (control) area was adjacent to the west side of the R\&FA in an uncontaminated area of Group 61 (Figure 5). Arrangements were made with a local contractor to perform initial soil mixing of the areas during October 1993. Because regulatory agencies require explosives-contaminated soils to remain in contact with the soil surface during any mixing operations, initial mixing was completed using the following method.

Along one edge of the area, parallel with the original furrows, a road grader was used to excavate a trench to a depth about 15 to $20 \mathrm{~cm}$ (6 to 8 in.) below the original furrow bottom. Soil from the trench was rolled along the length of the blade to mix the surface soil with soil from the lower depths. A second trench was excavated parallel and adjacent to the original trench and the soil was rolled along the blade into the first trench. This operation was repeated across the width of the area, then a disk was used to mix the soil and smooth the surface. Following disking, the soil was mixed again using the road grader, but mixing began at the opposite edge of the area. This sequence of soil mixing was repeated several times in an attempt to uniformly distribute TNTcontaminated soil throughout the upper 15 to $20 \mathrm{~cm}$ (0 to 6 in.) of the soil.

After each session of grading and disking, five soil samples were taken from random locations near each corner and near the center of the area. Each sample was mixed, and a 10-g aliquot was removed and analyzed for TNT using the field method developed by Jenkins (1990) with a portable spectrophotometer. If the results of the five samples were not within $20 \%$ of each other, the area was graded and disked again. Equipment was washed following the mixing operation in each area to prevent cross-contamination among the three areas. 


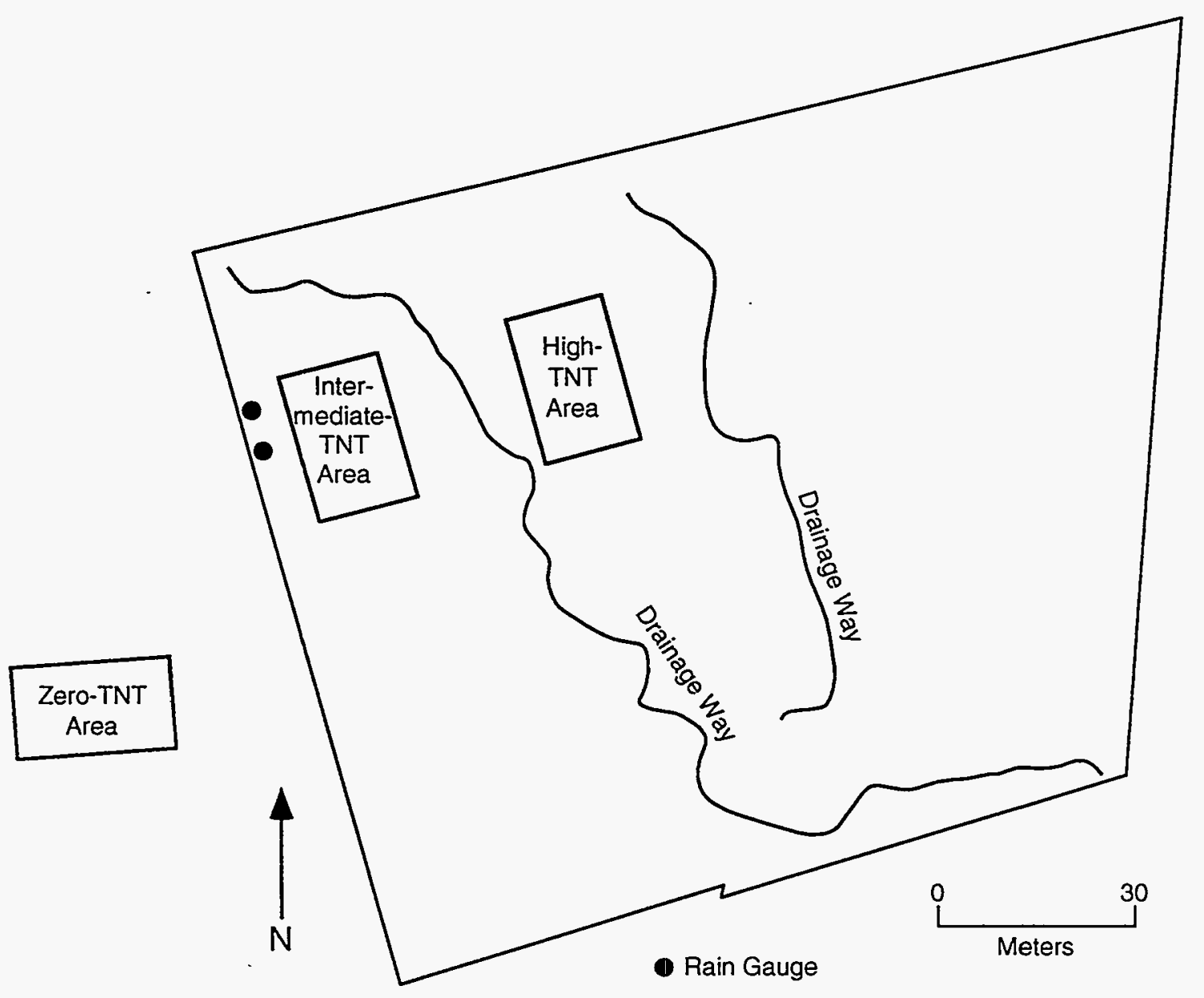

FIGURE 5 TNT Area Locations at Group 61, Joliet Army Ammunition Plant

Following the initial soil mixing and sample collection, each area was divided into 4-m by 4-m (13.1-ft by 13.1-ft) plots. The level of organic material addition, type of crop, and replicate number for each plot in each of the three areas were randomly assigned (Figure 6). Application and incorporation of chopped smooth bromegrass hay (the organic material added to the soil) was the next step in plot preparation. The hay was purchased from, and delivered and chopped by a local farmer. The original experimental design included the addition of chopped hay at rates of 5\% and $10 \%$, by weight, equivalent to the upper $17 \mathrm{~cm}(6.6 \mathrm{in}$.) of soil. The amounts of chopped hay, corrected for moisture content, at these rates were 231 and $462 \mathrm{~kg} \mathrm{plot}^{-1}$ (509 and $1018 \mathrm{lb}$ plot $^{-1}$ ), respectively. However, using available equipment, a maximum of only $2 \%$ chopped hay could effectively be incorporated into the soil by rototilling. As a result, the experimental design was changed from $5 \%$ and $10 \%$ to $1 \%$ and $2 \%$ additions of chopped hay, which was equal to 58 or $116 \mathrm{~kg} \mathrm{plot}^{-1}$ (128 or $256 \mathrm{lb}$ plot $^{-1}$ ). The required amount of chopped hay for each plot was weighed, spread over the plot surface, and incorporated into the soil using a tractor-mounted rototiller with an effective tillage depth of about $15 \mathrm{~cm}$ (6 in.). Two applications were necessary to complete the $2 \%$ addition; the plots were rototilled after each application. 


\begin{tabular}{|c|c|c|c|}
\hline $\begin{array}{l}\text { Plot 1 } \\
\text { Explosive High } \\
\text { Organic Level } 2 \% \\
\text { Oats } \\
\text { Replicate } 2\end{array}$ & $\begin{array}{l}\text { Plot } 2 \\
\text { Explosive High } \\
\text { Organic Level } 0 \% \\
\text { Oats } \\
\text { Replicate } 3\end{array}$ & $\begin{array}{l}\text { Plot } 3 \\
\text { Explosive High } \\
\text { Organic Level } 0 \% \\
\text { Oats } \\
\text { Replicate } 4\end{array}$ & $\begin{array}{l}\text { Plot } 4 \\
\text { Explosive High } \\
\text { Organic Level } 2 \% \\
\text { Ryegrass } \\
\text { Replicate } 1\end{array}$ \\
\hline $\begin{array}{l}\text { Plot } 5 \\
\text { Explosive High } \\
\text { Organic Level } 2 \% \\
\text { Ryegrass } \\
\text { Replicate } 4\end{array}$ & $\begin{array}{l}\text { Plot } 6 \\
\text { Explosive High } \\
\text { Organic Level } 1 \% \\
\text { Ryegrass } \\
\text { Replicate } 1\end{array}$ & $\begin{array}{l}\text { Plot } 7 \\
\text { Explosive High } \\
\text { Organic Level } 2 \% \\
\text { Oats } \\
\text { Replicate } 1\end{array}$ & $\begin{array}{l}\text { Plot } 8 \\
\text { Explosive High } \\
\text { Organic Level } 2 \% \\
\text { Oats } \\
\text { Replicate } 4\end{array}$ \\
\hline $\begin{array}{l}\text { Plot } 9 \\
\text { Explosive High } \\
\text { Organic Level } 0 \% \\
\text { Oats } \\
\text { Replicate } 1\end{array}$ & $\begin{array}{l}\text { Plot } 10 \\
\text { Explosive High } \\
\text { Organic Level } 2 \% \\
\text { Oats } \\
\text { Replicate } 3\end{array}$ & $\begin{array}{l}\text { Plot } 11 \\
\text { Explosive High } \\
\text { Organic Level 1\% } \\
\text { Oats } \\
\text { Replicate } 2\end{array}$ & $\begin{array}{l}\text { Plot } 12 \\
\text { Explosive High } \\
\text { Organic Level } 2 \% \\
\text { Ryegrass } \\
\text { Replicate } 2\end{array}$ \\
\hline $\begin{array}{l}\text { Plot } 13 \\
\text { Explosive High } \\
\text { Organic Level } 0 \% \\
\text { Ryegrass } \\
\text { Replicate } 4\end{array}$ & $\begin{array}{l}\text { Plot } 14 \\
\text { Explosive High } \\
\text { Organic Level } 1 \% \\
\text { Ryegrass } \\
\text { Replicate } 2\end{array}$ & \begin{tabular}{|l|} 
Plot 15 \\
Explosive High \\
Organic Level $1 \%$ \\
Ryegrass \\
Replicate 3
\end{tabular} & $\begin{array}{l}\text { Plot } 16 \\
\text { Explosive High } \\
\text { Organic Level } 2 \% \\
\text { Ryegrass } \\
\text { Replicate } 3\end{array}$ \\
\hline $\begin{array}{l}\text { Plot } 17 \\
\text { Explosive High } \\
\text { Organic Level } 1 \% \\
\text { Oats } \\
\text { Replicate } 4\end{array}$ & \begin{tabular}{|l|} 
Plot 18 \\
Explosive High \\
Organic Level $0 \%$ \\
Ryegrass \\
Replicate 1
\end{tabular} & \begin{tabular}{|l|} 
Plot 19 \\
Explosive High \\
Organic Level $0 \%$ \\
Ryegrass \\
Replicate 2
\end{tabular} & $\begin{array}{l}\text { Plot } 20 \\
\text { Explosive High } \\
\text { Organic Level 1\% } \\
\text { Ryegrass } \\
\text { Replicate } 4\end{array}$ \\
\hline $\begin{array}{l}\text { Plot } 21 \\
\text { Explosive High } \\
\text { Organic Level } 0 \% \\
\text { Oats } \\
\text { Replicate } 2\end{array}$ & \begin{tabular}{|l|} 
Plot 22 \\
Explosive High \\
Organic Level 0\% \\
Ryegrass \\
Replicate 3
\end{tabular} & \begin{tabular}{|l|} 
Plot 23 \\
Explosive High \\
Organic Level $1 \%$ \\
Oats \\
Replicate 3
\end{tabular} & $\begin{array}{l}\text { Plot } 24 \\
\text { Explosive High } \\
\text { Organic Level } 1 \% \\
\text { Oats } \\
\text { Replicate } 1\end{array}$ \\
\hline
\end{tabular}

FIGURE 6 Plot Layout for the High-TNT Area at Group 61, Joliet Army Ammunition Plant 
On 28 October 1994, fertilizer was applied to all plots at a rate equivalent to $224 \mathrm{~kg} \mathrm{ha}^{-1}$ (200 lb acre-1) nitrogen and $49 \mathrm{~kg} \mathrm{ha}^{-1}\left(44 \mathrm{lb}^{-1} \mathrm{acre}^{-1}\right)$ phosphorus. This rate of fertilization was considered necessary to aid in the decomposition of the chopped hay and correct the low level of available phosphorus in the soil at the R\&FA (Banwart 1989, unpublished data). Following the application of fertilizer, all plots were rototilled and seeded. The small grain crop was 'Cardinal' soft red winter wheat seeded at $135 \mathrm{~kg} \mathrm{ha}^{-1}\left(120 \mathrm{lb}^{\mathrm{bcre}}-1\right)$ and the forage was common perennial ryegrass seeded at $13.5 \mathrm{~kg} \mathrm{ha}^{-1}(12 \mathrm{lb}$ acre-1). Both wheat and ryegrass seed were hand broadcast and the soil surface lightly raked after seeding to cover the seed.

Researchers visited the experimental site at intervals to observe crop growth and development, collect soil samples, and service precipitation and temperature monitoring equipment. Inspection of plots during the winter revealed that the winter wheat and ryegrass had failed to germinate on all plots, including the control plots. All of the plots were tilled using the tractormounted rototiller and replanted on 22 March 1994. Procedures used were the same as those used during the October planting with one exception: 'Ogle' oat, broadcast at $125 \mathrm{~kg} \mathrm{ha}^{-1}$ (112 lb acre $^{-1}$ ), was planted in place of the winter wheat as the small grain crop.

Rainfall at the site remained well below normal through June, resulting in poor stand establishment of both oat and ryegrass on all plots, again including the control plots. On 7 June 1994, barren areas in all of the plots were raked, reseeded with oat or ryegrass, and the seed covered by lightly raking the soil.

\subsection{Sample and Data Collection}

A composite soil sample was collected from each plot immediately following seeding. The following method was developed and used to reduce potential variation caused by random subsample collection within a plot. A rope was stretched between opposite corners of a 4-m by 4-m plot, and points were marked at $2.1,2.8$, and $3.5 \mathrm{~m}(6.9,9.2,11.5 \mathrm{ft})$ from one corner. Locations under the marks corresponded to the center and two comers of the center square meter of the 4-m by 4-m plots. Soil subsamples were collected at each location along the rope from the 0 - to 15 -cm (0- to 6-in.) depth using a $2.5-\mathrm{cm}$ (1-inch) -diameter soil probe. The rope was then stretched between the other two comers of the plot and subsamples were collected at the outer two locations along the rope. The soil from these five points was combined into a composite soil sample and bagged for transport to a laboratory at the University of Hlinois at Urbana-Champaign for explosives analyses. A split of the initial composite soil sample from each plot was returned to the Argonne National Laboratory (ANL) soil analytical laboratory for soil characterization. The probe was cleaned after sampling at each plot to prevent cross-contamination between plots.

Composite soil samples were collected from each treatment plot in the two TNTcontaminated areas using the method described above. A total of 72 soil samples were collected on nine dates starting before the chopped hay additions were made on 15 October 1993 through the final crop harvest on 21 September 1994. 
Oat harvest and initial ryegrass samples were collected on 19 July 1994 . Plant shoots from within the center square meter of each plot were clipped about $2.5 \mathrm{~cm}$ (1 in.) above the soil surface. Care was taken not to include plant material that had been in direct contact with the soil and to prevent contact of the plants sampled with the soil. Ryegrass had not become established on many of the plots in the high-TNT area; if sufficient ryegrass shoots for a sample were not available in a plot, invading vegetation was sampled. Plant shoots from each plot were bagged as a single sample, but oat grain was separated from the straw in the laboratory for separate analysis.

Only oat root samples were collected because a second sampling of the ryegrass crop was planned. Soil in the root zone of the oat plants was loosened, the root mass was extracted, excess soil was removed, and the roots were bagged for transport to the analytical laboratory. A second sampling from the ryegrass shoots was conducted on 21 September 1994 using the procedure described above.

\subsection{Sample Analyses}

Soil and crop analyses for explosives were performed in a USAEC-approved laboratory at the University of Illinois at Urbana-Champaign. Samples were processed and analyzed for explosives using the same procedures and methods used for the existing vegetation study (Section 5.2).

Soil samples for assessing soil fertility were analyzed in the soil laboratory at ANL. Soil samples were air-dried and processed using methods adapted from Sobek et al. (1978). The fertility parameters assessed were (1) easily oxidizable carbon by the Walkley-Black method (Nelson and Sommers 1982), (2) cation exchange capacity (CEC) by the $\mathrm{NaOAc} \mathrm{NaCl}-\mathrm{MgNO} 3$ method (Rhoades 1982), and (3) soil pH in water, 1:1 (Jones 1980a). Available phosphorus was determined by Bray P1 extraction (Jones 1980b). Other major plant nutrients measured were exchangeable potassium, calcium, magnesium, and sodium by ammonium-acetate extraction (Jones 1980c). Total Kjeldahl nitrogen (TKN) was determined by industrial method 369-75A/B, developed for Technicon Industrial Systems (1977). Computer programs were developed at ANL to process and summarize the results of fertility parameter analysis. A general linear model (GLM) procedure of the statistical analysis system (SAS) programs (Ray 1982) was used to statistically compare analytical results for soils from individual plots. A statistical analytical concern was maintaining a 0.05 level of significance while making multiple t-test comparisons among treatments (i.e., TNT levels and organic material addition levels). The multiple comparison problem was resolved by using Sidak's pairwise $t$ tests (Miller 1966), in which pairwise t tests are performed for differences between means, and levels are adjusted according to Sidak's inequality for all means. This procedure maintains a 0.05 level of significance for comparisons among the means (Carns 1994). 


\subsection{Results and Discussion}

\subsubsection{Soil Fertility}

Fertility parameters measure the amounts of various plant nutrients, related materials (e.g., easily oxidizable carbon [C], TKN), and chemical reactions (e.g., pH, CEC) that occur in the soil. These parameters, along with climatic conditions and concentrations of toxic materials (e.g., TNT), directly influence crop establishment, growth, and development. Statistically significant differences in fertility parameters among treatments (i.e., TNT level and organic addition) would suggest conditions that could result in observable differences in crop establishment, growth, and development on various treatment plots. However, statistically significant differences in fertility parameters may not result in biologically significant differences in crop growth. A comparatively small numeric difference between means can result in a statistically significant difference if replicate values of a fertility parameter are relatively uniform across sampling units (plots). Plants respond to a continuum of fertility parameter values, and small numeric changes in parameter values may not be reflected in crop growth. Therefore, a small, statistically significant numeric difference between fertility parameter means may not result in a significant difference in crop growth.

Table 3 lists the means of analytical results of the soil fertility parameters for the nine treatments (i.e., three TNT levels with three organic additions). The inherent differences between the exposed subsoil and/or till in the zero- and intermediate-TNT areas compared with the mixed native soil in the high-TNT area account for significantly higher levels of exchangeable $\mathrm{Ca}$ and soil $\mathrm{pH}$ and significantly lower levels of exchangeable potassium (K), magnesium $(\mathrm{Mg})$, and $\mathrm{TKN}$ in the zero- and intermediate-TNT areas compared with the high-TNT area. The influence of the organic material additions is reflected in the TKN and $C$ values, although differences among organic addition levels within the areas were not significant. These two parameters (TKN and C) increased with increasing application of chopped hay.

Fertility parameters are within the range for acceptable crop establishment, growth, and development with two exceptions. All but two of the treatments (1\% and $2 \%$ organic addition in the high-TNT area) are below $15 \mathrm{mg} \mathrm{kg}^{-1}$ exchangeable phosphorus (P), the level at which a response to $\mathrm{P}$ fertilization is expected in most crops (Doll and Lucas 1973). Soil pH is also higher than the recommended value of 6.5 to 7.0 for most agricultural crops (Hausenbuiller 1972). However, these two parameters were probably not factors in crop growth or TNT uptake because $\mathrm{P}$ levels were low and $\mathrm{pH}$ values were high in all plots.

\subsubsection{Crop Establishment, Growth, and Development}

Climatic conditions, as well as soil fertility, can significantly influence the establishment, growth, and development of crops. Both precipitation and air temperature were monitored at the 
TABLE 3 Mean Soil Parameters, 0- to 15-cm Depth, from the Ridge and Furrow Area, Group 61, Joliet Army Ammunition Plant on 2 November 1993

\begin{tabular}{|c|c|c|c|c|c|c|c|c|c|c|}
\hline \multirow[b]{2}{*}{ TNT Level } & \multirow{2}{*}{$\begin{array}{c}\text { Organic } \\
\text { Material } \\
\text { Addition } \\
(\%)\end{array}$} & \multicolumn{9}{|c|}{ Parameter } \\
\hline & & $\begin{array}{c}\mathrm{Ca} \\
\left(\mathrm{mg} \mathrm{kg}^{-1}\right)\end{array}$ & $\begin{array}{c}M g \\
\left(m g ~ k g^{-1}\right)\end{array}$ & $\begin{array}{c}\mathrm{Na} \\
\left(\mathrm{mg} \mathrm{kg}^{-1}\right)\end{array}$ & $\begin{array}{c}\mathrm{K} \\
\left(\mathrm{mg} \mathrm{kg}^{-1}\right)\end{array}$ & $\begin{array}{c}\mathrm{CEC}^{\dagger} \\
\left(\mathrm{cmol} \mathrm{kg}^{-1}\right)\end{array}$ & $\begin{array}{c}\text { TKN‡ } \\
\left(\mathrm{mg} \mathrm{kg}^{-1}\right)\end{array}$ & $\underset{\left(g \mathrm{~kg}^{-1}\right)}{\mathrm{C}}$ & $\begin{array}{c}\mathrm{P} \S \\
\left(\mathrm{mg} \mathrm{kg}^{-1}\right)\end{array}$ & $\mathrm{pH}$ \\
\hline Highn & 0 & $2710^{b(\#)}$ & $637^{a}$ & $5.22^{b}$ & $255^{b c}$ & $47.0^{a b}$ & $2600^{a}$ & $27.6^{b c}$ & $13.6^{a b}$ & $7.0^{\mathrm{cd}}$ \\
\hline High & 1 & $2720^{b}$ & $637^{a}$ & $3.67^{b}$ & $370^{a b}$ & $50.6^{a}$ & $2870^{a}$ & $32.8^{a b}$ & $19.7^{a}$ & $7.0^{\mathrm{cd}}$ \\
\hline High & 2 & $2640^{b}$ & $659^{a}$ & $7.43^{\mathrm{ab}}$ & $448^{a}$ & $47.6^{\mathrm{ab}}$ & $2930^{a}$ & $39.9^{\mathrm{a}}$ & $17.6^{a}$ & $6.9^{d}$ \\
\hline Intermediate & 0 & $3680^{a b}$ & 498 abc & $11.1^{a b}$ & $121^{c}$ & $37.7^{a b}$ & $1140^{b}$ & $12.7^{d}$ & $5.77^{b c}$ & $7.6^{a b}$ \\
\hline Intermediate & 1 & $3320^{a b}$ & 559 ab & $11.1^{\mathrm{ab}}$ & $225^{c}$ & $43.3^{a b}$ & $1290^{b}$ & $17.9^{d}$ & $13.6^{a b}$ & $7.4^{b c}$ \\
\hline Intermediate & 2 & $3170^{a b}$ & $648^{a}$ & $15.8^{a}$ & $228^{c}$ & $44.5^{a b}$ & $1360^{b}$ & $20.2^{\mathrm{cd}}$ & $12.7 \mathrm{abc}$ & $7.4^{b c}$ \\
\hline Zero & 0 & $4480^{a}$ & $383^{b c}$ & $4.24^{b}$ & $150^{c}$ & $38.9^{a b}$ & $990^{b}$ & $13.7^{d}$ & $3.37^{c}$ & $8.0^{a}$ \\
\hline Zero & 1 & $4010^{\mathrm{ab}}$ & $351^{c}$ & $3.84^{b}$ & $137^{c}$ & $37.8^{a b}$ & $900^{b}$ & $14.5^{d}$ & $6.35^{b c}$ & $8.0^{a}$ \\
\hline Zero & 2 & $3710^{a b}$ & $393^{b c}$ & $3.88^{b}$ & $171^{\mathrm{c}}$ & $33.8^{\mathrm{b}}$ & $1250^{b}$ & $18.9^{\mathrm{cd}}$ & $6.55^{b c}$ & $8.0^{\mathrm{a}}$ \\
\hline Detection Limits & & 0.10 & 0.05 & 0.05 & 0.10 & 0.10 & 0.10 & 0.50 & 0.01 & \\
\hline
\end{tabular}

\section{† Cation Exchange Capacity}

‡ Total Kjeldahl Nitrogen

$\S$ Bray P1 extraction

I $n=8$ (in all cases)

\# Means for a parameter followed by the same letter are not significantly different $(P \leq 0.05)$ by Sidek's pairwise $t$ test. 
site during the crop uptake experiment to determine whether there were major departures from the long-term averages for the area. The 29-year (1931 to 1960) normal monthly data, collected near Morris, located about $19 \mathrm{~km}$ (12 mi) west of the site, were used for comparison. A review of the air temperature data indicates that monthly means were near normal during the period when crops were established and growing; the largest departure, about $+2^{\circ} \mathrm{C}\left(3.6^{\circ} \mathrm{F}\right)$, was observed during May 1994. This minor variation in air temperature would not influence crop establishment or growth. Figure 7 illustrates precipitation at the site from October 1993 through September 1994. These data indicate that the site received below-normal precipitation from December 1993 through June 1994. The below-normal precipitation during the winter months resulted in dry seedbed conditions. The accumulated precipitation deficiency from April through June was $137 \mathrm{~mm}$ (5.4 in.). This deficiency resulted in below-normal stand establishment and growth of both crops.

The late October planting date and below-normal rainfall resulted in a complete crop failure of the fall seeding. To continue the experiment, all plots were tilled and seeded again on $22 \mathrm{March}$ 1994. Oat was planted in place of the wheat as the small grain crop. Below-normal rainfall continued throughout the spring and early summer, resulting in thin stands of ryegrass and oat on all plots. On 7 June, spot reseeding was completed on all plots, resulting in uneven stands of both crops, but sufficient crop establishment to continue the experiment.

By late June, it was apparent that ryegrass was not becoming established on most of the plots in the high-TNT area; only scattered plants were present on several plots. The soil surface in these plots had a reddish color, indicating the presence of TNT. Comparison of TNT concentrations of barren plots with those of plots exhibiting crop growth revealed that TNT levels were generally higher on the barren plots. The level of hay addition did not influence the

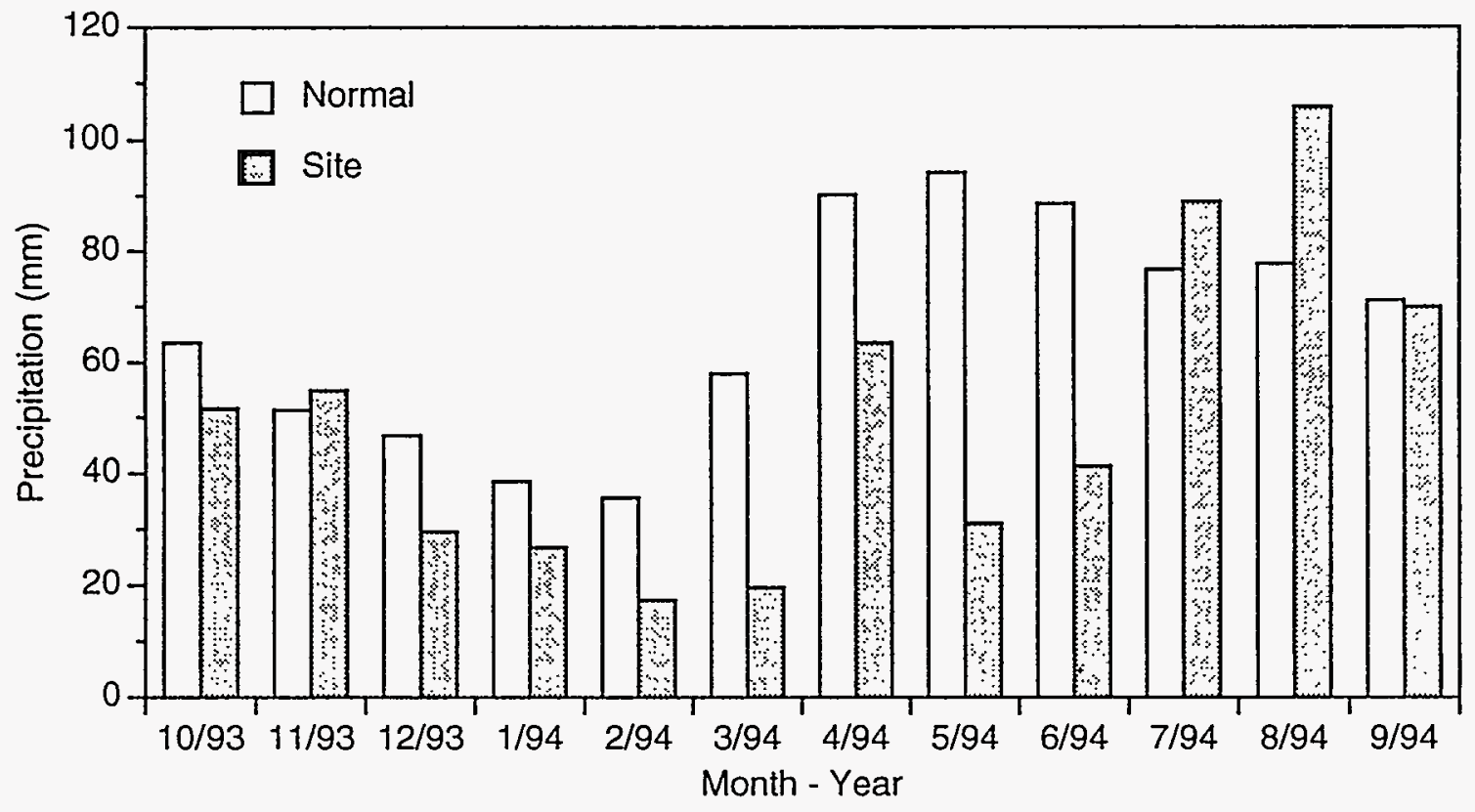

FIGURE 7 Normal and Actual Precipitation in the Group 61 Area at the Joliet Army Ammunition Plant during the Crop Study 
establishment of ryegrass in the high-TNT area because all but one ryegrass plot remained barren, indicating some difference in TNT tolerance between ryegrass and oat. During the summer, some differences in crop growth and development among plots in the intermediate-TNT area and control area were also observed. Establishment and growth of ryegrass and oat were better on plots with hay additions, and some apparent differences between levels of hay addition were noted, probably in response to improved soil moisture conditions caused by the added hay incorporated into the surface soil.

During the initial crop harvest on 19 July, differences in crop growth and stage of development were observed and recorded. In the zero-TNT (control) area plots with $2 \%$ hay added, ryegrass was generally taller and greener compared with other plots. Oat plants on $2 \%$ plots were taller, but was not as mature as plants on plots with lower levels of hay addition. On the $1 \%$ hay addition plots, ryegrass was somewhat shorter, but green, and oat was shorter and fully matured. On the $0 \%$ hay addition plots, ryegrass was shortest, and stands were only about one-fourth to one-half of those on plots with hay additions. Oat stand establishment and growth were also the poorest on the $0 \%$ hay plots. Differences in stand establishment, growth, and maturity in crops were attributed to probable differences in moisture conditions caused by the different levels of hay added to the soil.

Differences in crop response caused by hay additions were also observed in the intermediate-TNT area. On the $2 \%$ plots, ryegrass growth was good, but weedy species and alfalfa had become established on several plots. Stands of oat on the $2 \%$ plots varied, but the plants were more mature than those in the control area. Stands and growth of ryegrass and oat on the $1 \%$ plots were slightly less than on the $2 \%$ plots. Stands of ryegrass were thinnest and stands of oat shortest on the $0 \%$ hay plots. Differences in growth and development of crops were more pronounced in the intermediate-TNT area than in the control area. Banwart and Hassett (1990) observed similar crop responses in their greenhouse investigation. Improved crop response on plots with hay additions was probably caused by improved soil moisture conditions.

Crop establishment and growth in the high-TNT area were generally poor compared with the intermediate-TNT and zero-TNT plots. Ryegrass was not established on any of the $0 \%$ and $1 \%$ hay addition plots, and only one of the four plots with $2 \%$ hay added contained any ryegrass. The ryegrass stand on this plot was about one-fourth that of the stands on the $2 \%$ plots on either the intermediate-TNT or the control plots. Invading weedy species, mainly velvet-leaf (Abutilon theophrasti Medic.) and alfalfa, were present on a few of the ryegrass plots where $2 \%$ hay had been added. The stands of oat on most plots were thin, short, and immature. Plots with $1 \%$ and $2 \%$ hay addition had slightly better oat growth than $0 \%$ plots, but differences in both growth and development were small. Although TNT concentrations were extremely variable among plots in both TNT areas (intermediate and high), establishment and growth suggest that oat is more tolerant of TNT than ryegrass.

The condition of the ryegrass was again assessed during a second sampling on 21 September. Ryegrass on control and intermediate TNT plots was still actively growing and taller than in July. Differences among plots with different hay addition levels were less pronounced than during July, probably due to more rainfall and better soil moisture conditions 
from July through September. Ryegrass on the single $2 \%$ hay addition plot in the high-TNT area was still actively growing, and invading vegetation had not become established on most of the barren ryegrass plots in the high-TNT area.

\subsubsection{TNT Uptake by Crops}

All oat root, straw, and grain samples collected during July and ryegrass shoot samples collected during July and September were analyzed for TNT, its degradation products, and other explosive compounds. Analytical results of the oat straw, grain, and ryegrass shoots are not listed in this report because neither TNT nor any of its degradation products was found in the aboveground plant organs of either crop on either collection date. These results support the results of the existing vegetation study conducted at JAAP in 1993, and show that neither TNT nor any of its degradation products is translocated to aboveground crop organs grown on TNT-contaminated soils.

Analytical results of oat root samples from the high- and intermediate-TNT areas are listed in Table 4. TNT was not detected in any root samples, but 4A-DNT and/or 2A-DNT were detected in 9 of the 24 oat root samples from TNT-contaminated plots. There appears to be a relationship between detection of $4 \mathrm{~A}-\mathrm{DNT}$ and/or $2 \mathrm{~A}-\mathrm{DNT}$ in oat roots and soil TNT concentrations, as indicated by eight of the nine oat root samples from the high-TNT area that contained 4A-DNT and/or 2A-DNT. However, comparison of root 4A-DNT and/or 2A-DNT contamination and soil TNT concentrations shows no direct relationship; the root sample with the highest concentration of 4A-DNT and 2A-DNT (high-TNT level, 1\% hay, replicate 4) was collected from a plot with relatively low TNT concentration. Conversely, oat root samples that did not contain 4A-DNT and/or 2A-DNT were collected from soils with high TNT concentrations. Although oat roots were washed to remove surface soil before they were analyzed, there is no way to distinguish 4A-DNT and 2A-DNT in the root tissue from compounds remaining on the root surface. Oat plants have fibrous root systems, and the detection of these compounds may be due to contamination from soil not removed during root washing. These data support the lack of a relationship between soil TNT concentrations and the presence of 4A-DNT and 2A-DNT in or on roots that was demonstrated in the existing vegetation study.

Consumption of aboveground portions of crops grown on TNT-contaminated soil at the R\&FA at JAAP should not be considered an animal or human health concern. Neither TNT nor its degradation products were detected in any of the aboveground crop organs. However, crop shoots and roots may be contaminated with soil containing TNT, 4A-DNT, and 2A-DNT. 
TABLE 4 Concentrations of TNT and its Degradation Products in Oat Roots from the Ridge and Furrow Area, Group 61, Joliet Army Ammunition Plant on 17 July 1994

\begin{tabular}{|c|c|c|c|c|c|}
\hline \multirow[b]{2}{*}{$\begin{array}{l}\text { TNT } \\
\text { Level }\end{array}$} & \multirow{2}{*}{$\begin{array}{c}\text { Organic } \\
\text { Material } \\
\text { Addition } \\
(\%)\end{array}$} & \multirow[b]{2}{*}{$\begin{array}{c}\text { Replicate } \\
\text { Number }\end{array}$} & \multicolumn{3}{|c|}{ Concentration $\left(\mathrm{mg} \mathrm{kg} \mathrm{kg}^{-1}\right.$ ) } \\
\hline & & & TNT & 4A-DNT & 2A-DNT \\
\hline High & 0 & 1 & $<0.08^{\dagger}$ & 2.27 & 2.17 \\
\hline High & 0 & 2 & $<0.08$ & 2.16 & 1.93 \\
\hline High & 0 & 3 & $<0.08$ & 1.53 & $<0.20$ \\
\hline High & 0 & 4 & $<0.08$ & $<0.20$ & $<0.20$ \\
\hline High & 1 & 1 & $<0.08$ & $<0.20$ & $<0.20$ \\
\hline High & 1 & 2 & $<0.08$ & $<0.20$ & $<0.20$ \\
\hline High & 1 & 3 & $<0.08$ & 1.94 & 1.75 \\
\hline High & 1 & 4 & $<0.08$ & 21.0 & 32.2 \\
\hline High & 2 & 1 & $<0.08$ & $<0.20$ & $<0.20$ \\
\hline High & 2 & 2 & $<0.08$ & 5.79 & 3.82 \\
\hline High & 2 & 3 & $<0.08$ & 3.32 & 2.10 \\
\hline High & 2 & 4 & $<0.08$ & 1.32 & 1.21 \\
\hline Intermediate & 0 & 1 & $<0.08$ & $<0.20$ & $<0.20$ \\
\hline Intermediate & 0 & 2 & $<0.08$ & $<0.20$ & $<0.20$ \\
\hline Intermediate & 0 & 3 & $<0.08$ & $<0.20$ & $<0.20$ \\
\hline Intermediate & 0 & 4 & $<0.08$ & $<0.20$ & $<0.20$ \\
\hline Intermediate & 1 & 1 & $<0.08$ & 0.30 & 1.28 \\
\hline Intermediate & 1 & 2 & $<0.08$ & $<0.20$ & $<0.20$ \\
\hline Intermediate & 1 & 3 & $<0.08$ & $<0.20$ & $<0.20$ \\
\hline Intermediate & 1 & 4 & $<0.08$ & $<0.20$ & $<0.20$ \\
\hline Intermediate & 2 & 1 & $<0.08$ & $<0.20$ & $<0.20$ \\
\hline Intermediate & 2 & 2 & $<0.08$ & $<0.20$ & $<0.20$ \\
\hline Intermediate & 2 & 3 & $<0.08$ & $<0.20$ & $<0.20$ \\
\hline Intermediate & 2 & 4 & $<0.08$ & $<0.20$ & $<0.20$ \\
\hline
\end{tabular}

$\dagger$ Detection Limit. 


\section{Extractable TNT in Soil}

Results from greenhouse investigations (Banwart and Hassett 1990; Cataldo et al. 1993) indicate that levels of extractable TNT are reduced in soils with higher organic content or by adding organic material to soils. This portion of the experiment was intended to establish whether this relationship, observed under greenhouse conditions, also occurs in the field. The original experimental design for this study involved duplicating some of the variables tested by Banwart and Hassett (1990) in their greenhouse investigation. Two levels of soil TNT contamination with replicate plots of known and uniform soil contamination were required to statistically analyze the data. One major complicating factor in the field study was the heterogeneity of TNT contamination in the area and plot soils. Blending several kilograms of TNT-contaminated soil to obtain homogeneous soil for a greenhouse pot study can be a problem, but mixing megagrams of soil into the upper $15 \mathrm{~cm}$ ( $6 \mathrm{in}$.) of an area, or even a plot, to achieve a uniform concentration of TNT is almost impossible. The soil mixing problem was compounded by regulations that prohibited removal, mixing, and replacement of contaminated soil.

The original experimental design included use of the $5 \%$ and $10 \%$ organic material additions used in a previous greenhouse study. Incorporation of large volumes of chopped hay into the upper $15 \mathrm{~cm}$ ( $6 \mathrm{in}$.) of soil using the equipment available was impractical. The amounts of hay added to the soil were reduced to $1 \%$ and $2 \%$ - substantially less than the amounts used in the greenhouse study. These factors compromised the field investigation to determine changes in extractable TNT caused by the addition of organic material to the soil.

Extractable TNT concentrations in plot soils on eight collection dates following application of the chopped hay are shown for the high-TNT area in Table 5 and for the intermediate-TNT area in Table 6. Concentrations of TNT and degradation products from individual plots for the three TNT areas with means by organic material addition on the nine collection dates are given in the Appendix. These data show the variability in the extractable TNT concentrations among replicate plots of a treatment on different collection dates. The influence of tilling the plots on $22 \mathrm{March}$ to reseed the crops is evident. Extractable TNT concentrations in many plots dramatically changed, and often increased, following tillage. These changes may result from the redistributed TNT in the soil profile caused by an increase in the tillage depth; the tillage depth in the soil profile increased because the volume of the ground hay decreased during the winter. There are also wide variations in TNT concentrations for individual plots between one sampling date and the next. Subsamples (for composite soil samples) were collected from the same locations in plots to reduce this variability. However, extractable TNT concentrations changed, and sometimes increased, by an order of magnitude from one collection date to the next. These differences are caused by the heterogeneity of TNT in plot soils.

Figure 8 shows the extractable TNT concentrations of soil in the high-TNT area (1\% hay addition, ryegrass, replicate four plot) during the study. The concentration of extractable TNT decreased by more than $82 \%$ from 28 October to 10 December and continued to decrease to only about $1.6 \%$ of the original concentration by 7 July. This decrease in extractable TNT concentration is similar to results reported by Banwart and Hassett (1990). However, the concentration 
TABLE 5 Extractable TNT Concentrations in Soil from the High-TNT Area on Eight Collection Dates

\begin{tabular}{|c|c|c|c|c|c|c|c|c|c|c|}
\hline \multirow{2}{*}{$\begin{array}{c}\text { Organic } \\
\text { Material } \\
\text { Addition } \\
(\%)\end{array}$} & \multirow[b]{2}{*}{ Crop } & \multirow[b]{2}{*}{$\begin{array}{c}\text { Replicate } \\
\text { Number }\end{array}$} & \multicolumn{8}{|c|}{ Concentration by Collection Date $\left(\mathrm{mg} \mathrm{kg}^{-1}\right)$} \\
\hline & & & $28-$ Oct-93 & 10-Dec-93 & 17-Feb-94 & 22-Mar-94 & 26-Apr-94 & 7-Jun-94 & 19-Jul-94 & 21-Sep-94 \\
\hline 0 & Oat & 1 & 874 & 755 & 679 & 599 & 344 & 1770 & 129 & 363 \\
\hline 0 & Oat & 2 & 402 & 398 & 322 & 4920 & 207 & 1910 & 5650 & 67 \\
\hline 0 & Oat & 3 & 362 & 736 & 386 & 2940 & 258 & 297 & 890 & 1950 \\
\hline 0 & Oat & 4 & 1110 & 183 & 179 & 491 & 2290 & 29 & 528 & 13 \\
\hline 0 & Ryegrass & 1 & 2330 & 1630 & 1240 & 1610 & 1370 & 89 & 2120 & 371 \\
\hline 0 & Ryegrass & 2 & 2330 & 797 & 1110 & 684 & 520 & 1540 & 810 & 53 \\
\hline 0 & Ryegrass & 3 & 855 & 1090 & 1580 & 5190 & 1110 & 2260 & 7790 & 2370 \\
\hline \multirow[t]{2}{*}{0} & Ryegrass & 4 & 1840 & 1540 & 3210 & 4250 & 1120 & 1240 & 3700 & 624 \\
\hline & & Mean & 1263 & 891 & 1088 & 2586 & 902 & 1142 & 2702 & 726 \\
\hline 1 & Oat & 1 & 585 & 426 & 489 & 384 & 150 & 1900 & 74 & 527 \\
\hline 1 & Oat & 2 & 401 & 1090 & 1880 & 3150 & 1920 & 2850 & 1590 & 1300 \\
\hline 1 & Oat & 3 & 1390 & 655 & 215 & 5780 & 1020 & 3050 & 1430 & 4510 \\
\hline 1 & Oat & 4 & 1300 & 972 & 958 & 2140 & 2200 & 2910 & 2110 & 819 \\
\hline 1 & Ryegrass & 1 & 292 & 254 & 185 & 213 & 360 & 521 & 220 & 97 \\
\hline 1 & Ryegrass & 2 & 2690 & 2470 & 4410 & 4690 & 4060 & 4650 & 12600 & 9150 \\
\hline 1 & Ryegrass & 3 & 1440 & 1240 & 905 & 1870 & 6770 & 3350 & 2290 & 3100 \\
\hline \multirow[t]{2}{*}{1} & Ryegrass & 4 & 2220 & 388 & 357 & 259 & 249 & 85 & 35 & 74 \\
\hline & & Mean & 1290 & 937 & 1175 & 2311 & 2091 & 2414 & 2544 & 2447 \\
\hline 2 & Oat & 1 & 252 & 95 & 173 & 556 & 110 & 39 & 87 & 102 \\
\hline 2 & Oat & 2 & 2340 & 990 & 1440 & 274 & 334 & 2325 & 134 & 44 \\
\hline 2 & Oat & 3 & 485 & 399 & 393 & 2450 & 191 & 383 & 111 & 682 \\
\hline 2 & Oat & 4 & 453 & 529 & 199 & 742 & 1730 & 102 & 259 & 167 \\
\hline 2 & Ryegrass & 1 & 72 & 120 & 20 & 76 & 144 & 7 & 27 & 18 \\
\hline 2 & Pyegrass & 2 & 968 & 1170 & 1010 & 2050 & 1720 & 23900 & 897 & 1460 \\
\hline 2 & Ryegrass & 3 & 1440 & 2290 & 1970 & 2670 & 2130 & 658 & 569 & 2380 \\
\hline \multirow[t]{2}{*}{2} & Ryegrass & 4 & 453 & 345 & 298 & 520 & 1020 & 1210 & 2450 & 351 \\
\hline & & Mean & 808 & 742 & 688 & 1167 & 922 & 3578 & 567 & 651 \\
\hline
\end{tabular}


TABLE 6 Extractable TNT Concentrations in Soil from the Intermediate-TNT Area on Eight Collection Dates

\begin{tabular}{|c|c|c|c|c|c|c|c|c|c|c|}
\hline \multirow{2}{*}{$\begin{array}{c}\text { Organic } \\
\text { Material } \\
\text { Addition } \\
(\%)\end{array}$} & \multirow[b]{2}{*}{ Crop } & \multirow[b]{2}{*}{$\begin{array}{l}\text { Replicate } \\
\text { Number }\end{array}$} & \multicolumn{8}{|c|}{ Concentration by Collection Date $\left(\mathrm{mg} \mathrm{kg}^{-1}\right)$} \\
\hline & & & $28-O c t-93$ & 10-Dec-93 & $17-F e b-94$ & 22-Mar-94 & 26-Apr-94 & 7-Jun-94 & 19-Jul-94 & 21-Sep-94 \\
\hline 0 & Oat & 1 & 113 & 107 & 148 & 113 & 83 & 31.7 & 183 & 21 \\
\hline 0 & Oat & 2 & 142 & 237 & 56 & 45.3 & 23.7 & 24.5 & 4.3 & 2.2 \\
\hline 0 & Oat & 3 & 9.9 & 6.1 & 5.3 & 6.6 & 4.0 & 26.7 & 4.5 & 0.7 \\
\hline 0 & Ryegrass & 2 & 1.0 & 3.1 & 1.2 & 2.9 & 5.5 & 3.1 & 0.5 & $<0.5$ \\
\hline 0 & Ryegrass & 3 & 262 & 230 & 362 & 239 & 163 & 101 & 80.3 & 17.9 \\
\hline \multirow[t]{2}{*}{0} & Ryegrass & 4 & 211 & 122 & 162 & 170 & 63.3 & 162 & 27.3 & 34 \\
\hline & & Mean & 170 & 151 & 133 & 111 & 201 & 87.7 & 47.9 & 203 \\
\hline 1 & Oat & 1 & 415 & 3950 & 240 & 871 & 8480 & 962 & 2068 & 2570 \\
\hline 1 & Oat & 2 & 76 & 46 & 49 & 28 & 44 & 25 & 5.9 & 11 \\
\hline 1 & Ryegrass & 3 & 127 & 114 & 66 & 136 & 68.8 & 69 & 3.1 & 953 \\
\hline \multirow[t]{2}{*}{1} & Ryegrass & 4 & 28 & 6.0 & 19 & 3.6 & 1.8 & 0.6 & 0.5 & 0.5 \\
\hline & & Mean & 150 & 573 & 89.1 & 159 & 1230 & 244 & 427 & 447 \\
\hline 2 & Oat & 1 & 70 & 41 & 18.2 & 26.1 & 7.3 & 6.6 & 104 & 3.9 \\
\hline 2 & Oat & 2 & 87 & 45 & 11.7 & 7.0 & $<0.5$ & 6.2 & 0.9 & 0.8 \\
\hline 2 & Oat & 3 & 20 & 1.4 & 3.0 & 1.7 & 0.7 & 0.7 & 0.9 & 0.4 \\
\hline 2 & Oat & 4 & 100 & 99 & 70 & 12.7 & 4.2 & 26.7 & 2.6 & 12 \\
\hline 2 & Ryegrass & 1 & 4.3 & 1.5 & 1.7 & 0.7 & 7.0 & $<0.5$ & 0.5 & $<0.5$ \\
\hline 2 & Ryegrass & 2 & 2.7 & 5.1 & 20.4 & 16 & 9.5 & $<0.5$ & 0.6 & 0.4 \\
\hline 2 & Ryegrass & 3 & 11 & 16 & 18.7 & 366 & 4.8 & 7.6 & 3.3 & 1.1 \\
\hline \multirow{2}{*}{2} & Ryegrass & 4 & 1.1 & $<0.5$ & 24.9 & $<0.5$ & 0.5 & $<0.5$ & $<0.5$ & $<0.5$ \\
\hline & & Mean & 37.0 & 29.9 & 21.1 & 61.5 & 4.9 & 8.1 & 16.1 & 3.1 \\
\hline
\end{tabular}




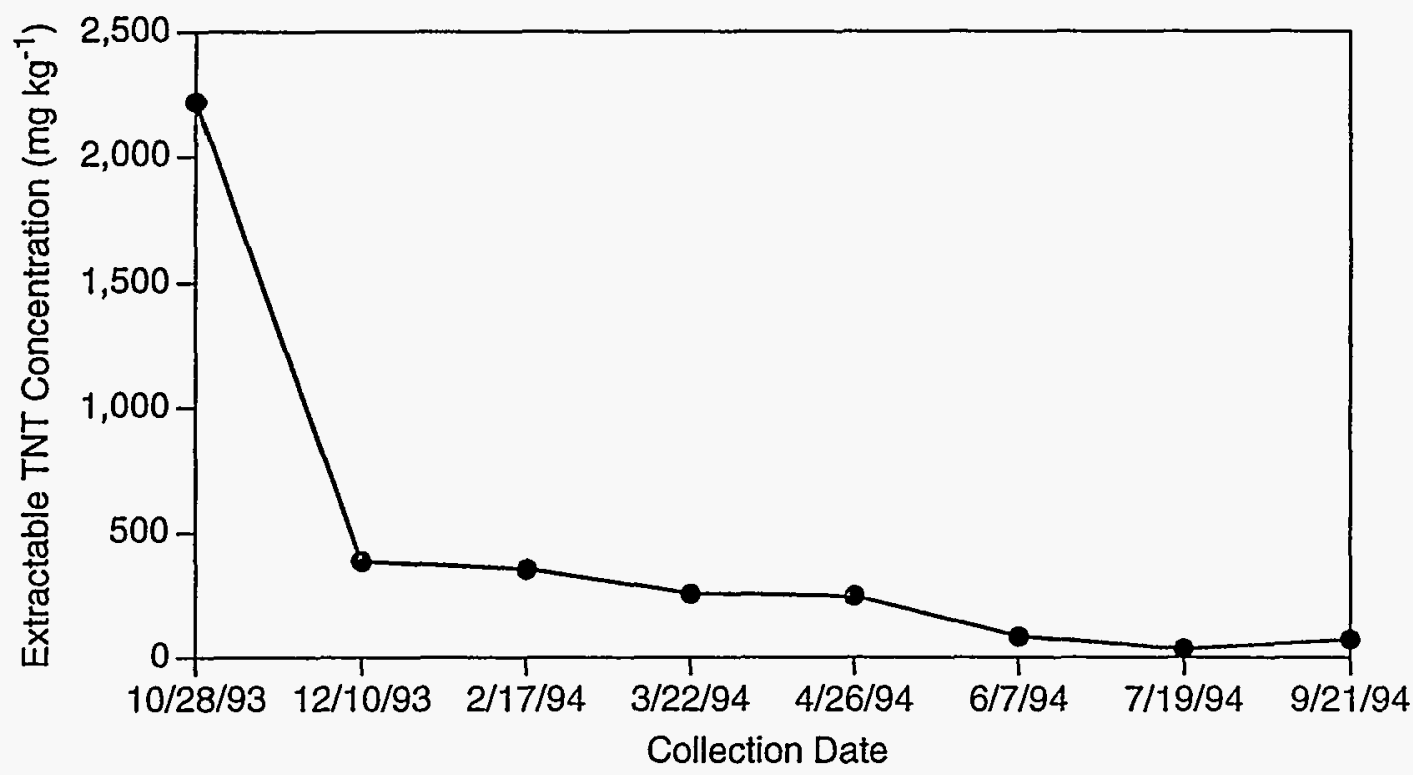

FIGURE 8 Relationship between Time and Mean Extractable TNT Concentrations for Plot 20 (High-TNT Area, 1\% Hay Addition, Ryegrass, Replicate 4)

increased slightly, to only about $3.4 \%$ of the original concentration, on 21 September. Of the 48 plots in this study, this one is the best example of the expected decrease of extractable TNT in soil. Unfortunately, results from this plot are not typical of the general response observed.

Figure 9 shows the mean concentration of extractable TNT in the high-TNT plot with three levels of hay addition on eight collection dates. Mean extractable TNT concentrations for all three hay addition levels decreased following the initial sampling, but this trend did not continue. The initial increase in TNT concentrations in all treatment plots on 22 March was due to tillage on that date. Most individual plot values varied widely, some by an order of magnitude, from one collection date to the next. This heterogeneity of TNT in plot soils prevents any meaningful interpretation of these data.

Figure 10 shows the mean concentration of extractable TNT in the intermediate-TNT area with three levels of hay addition on eight collection dates. Mean extractable TNT concentrations in plots with $2 \%$ hay added generally decreased during the study, with the exception of increases on 22 March and 19 July. The increase on 22 March was about $65 \%$ more than the original mean concentration; the increase on 19 July was double the mean concentration of the previous date (7 June). The increase on 22 March was probably due to tillage of the plot on that date - soil samples were collected after the plots were tilled. The mean increase on 19 July was caused by a very high value of $104 \mathrm{mg} \mathrm{kg}^{-1}$ extractable TNT in one plot compared with a mean of $1.25 \mathrm{mg} \mathrm{kg}^{-1}$ for the other seven plots. 


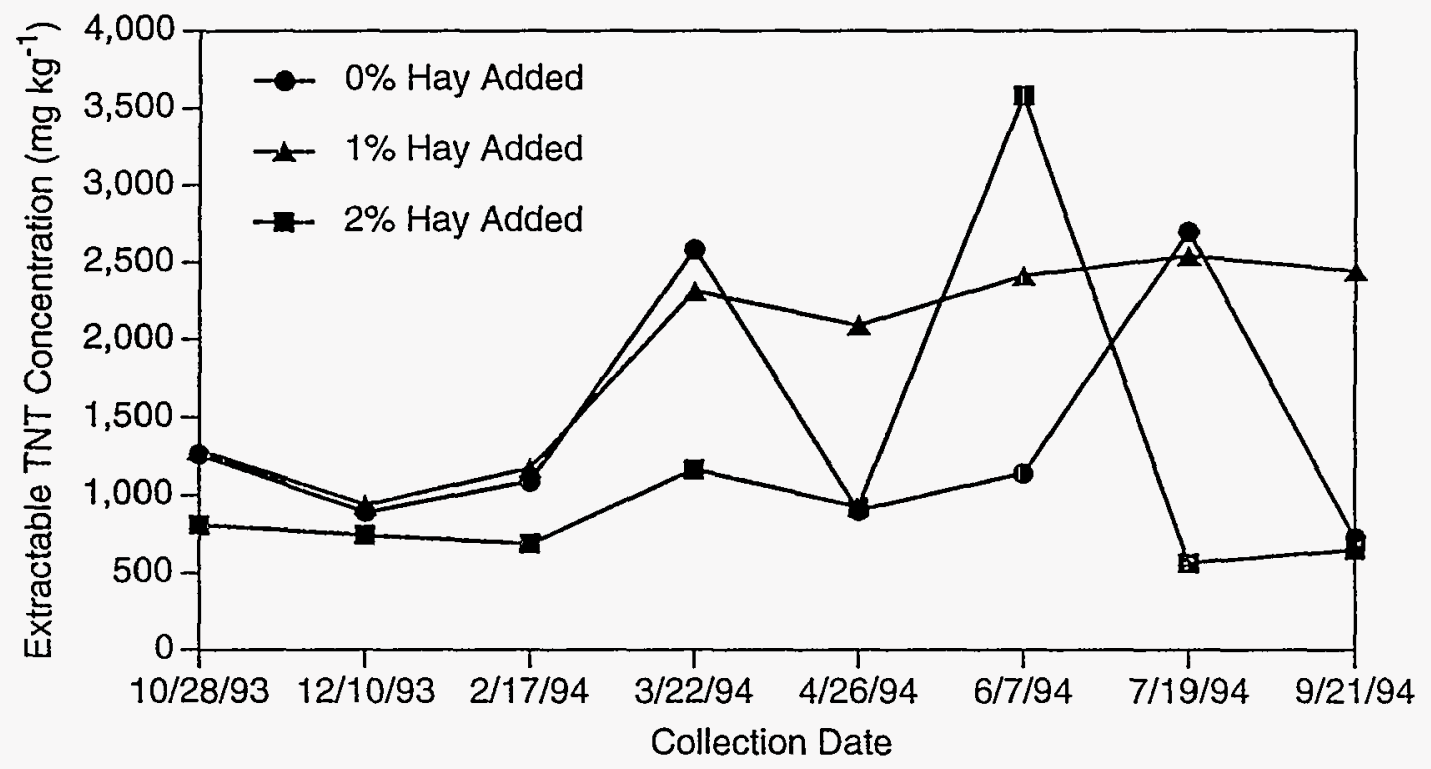

FIGURE 9 Relationship between Time and Mean Extractable TNT Concentrations for Three Hay Addition Levels in the High-TNT Area

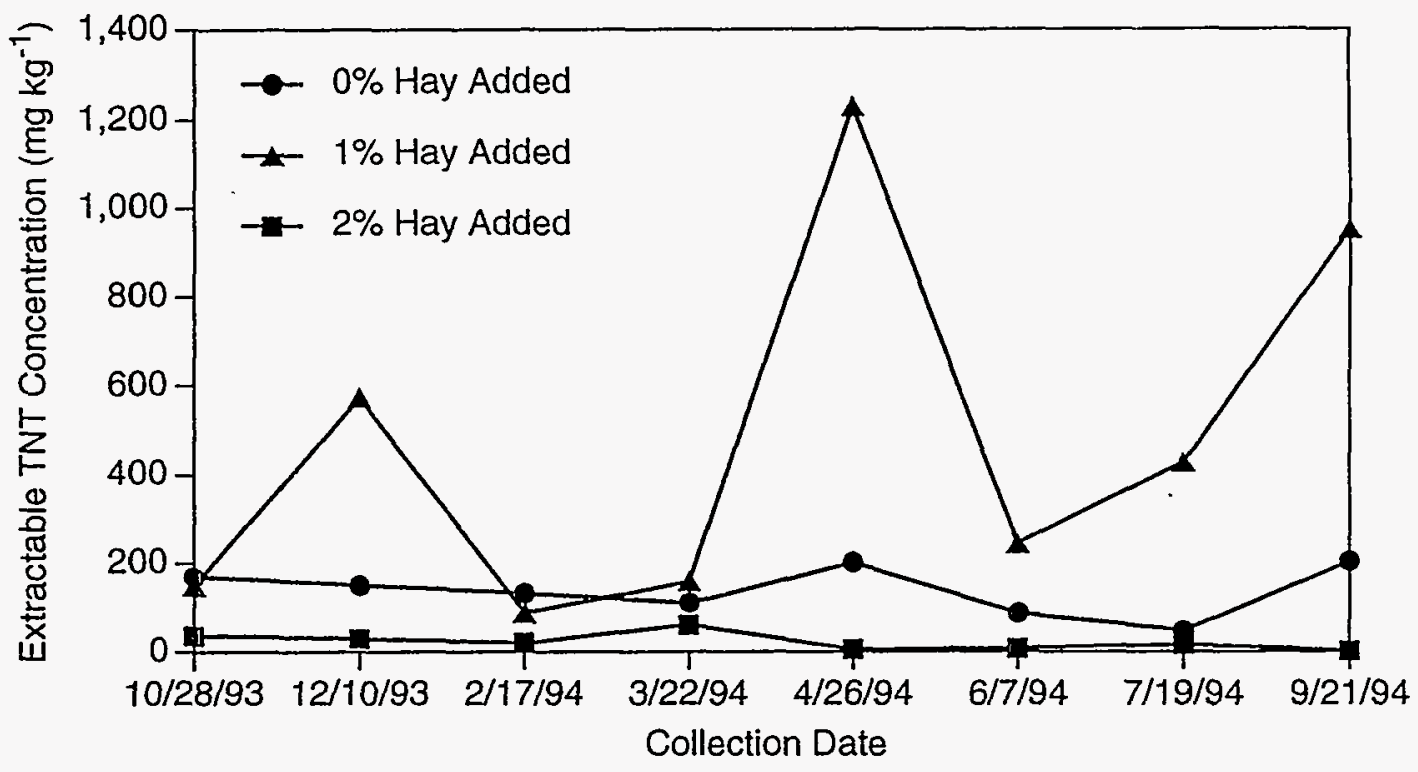

FIGURE 10 Relationship between Time and Mean Extractable TNT

Concentrations for Three Hay Addition Levels in the Intermediate-TNT Area 
Mean concentrations of TNT in the $0 \%$ hay plots also generally decreased during the experiment, with two notable exceptions. The first, on 26 April, probably was related to tilling on 22 March. The second increase, on 21 September, was due to two plots with high values. Without these two high values, the mean would have been $15.2 \mathrm{mg} \mathrm{kg}^{-1}$ (with these values, the mean was $203 \mathrm{mg} \mathrm{kg}^{-1}$ ). Means of TNT concentration from plots with $1 \%$ hay added show no trend except wide variability. Extractable TNT values in individual plots where one or more values were obtained for each sampling date were often one or two orders of magnitude higher than those in other plots.

Trends of the means shown in Figure 6 and of the $0 \%$ and 2\% hay additions shown in Figure 8 generally confirm results reported by Banwart and Hassett (1990) and Cataldo et al. (1993). One possible explanation for the decrease in extractable TNT is sorption of TNT degradation products by soil and/or organic particles. TNT is degraded to nitroaromatic amines that can chemically bind to soil and/or organic particles. Mixing and manipulation of TNTcontaminated soils exposes TNT molecules to additional soil or organic particles, thus reducing the amount of extractable TNT in the soil. Initial sorption is high, but the rate decreases over time because fewer and fewer free TNT molecules are available in the soil. Another potential explanation is that TNT is degraded by soil and/or rhizosphere microorganisms. Adding organic material to a soil increases nutrient levels, causing corresponding increases in microorganism activities and populations.

Concentrations of TNT degradation products (4A-DNT and 2A-DNT) determined for intermediate-TNT plot soil samples revealed the following trend: generally, if the concentration of extractable TNT was high, the concentrations of 4A-DNT and 2A-DNT were below detection limits. As extractable TNT levels decreased, concentrations of 4A-DNT and 2A-DNT increased to a maximum of about $15 \mathrm{mg} \mathrm{kg}^{-1}$. As the concentration of extractable TNT approached the detection limit, concentrations of these degradation products also decreased. The presence of 4A-DNT and 2A-DNT may indicate that soil and/or rhizosphere microorganisms are degrading TNT in soils if conditions for their survival are favorable. It is not possible, on the basis of the data generated by this study, to determine whether sorption or degradation was the major factor responsible for the decrease in extractable TNT concentrations in these soils. The decrease was probably caused by a combination of sorption and degradation and possibly other processes as well. 


\section{Conclusions}

Results from Phase I of this field experiment show that TNT and its degradation products are not translocated to the shoot in existing vegetation grown on TNT-contaminated soil. Low concentrations (less than or equal to $5.85 \mathrm{mg} \mathrm{kg}^{-1}$ ) of TNT were detected in 8 of the 31 root samples. These root samples also usually contained low concentrations of 4A-DNT (less than or equal to $5.71 \mathrm{mg} \mathrm{kg}^{-1}$ ) and 2A-DNT (less than or equal to $7.71 \mathrm{mg} \mathrm{kg}^{-1}$ ). The detection of TNT, 4A-DNT, and 2A-DNT in root samples is not related to TNT concentrations in soil near the roots. Root samples were washed before analysis; the low concentrations of these compounds may be caused by soil contamination. Root processing methods used in this experiment prevented researchers from distinguishing between compounds that were present in root tissues and those remaining on the root surface.

Phase II of the experiment, to determine TNT uptake by crops, revealed that ryegrass and oat growth improved with increased levels of hay added to the soil, but that this crop response was probably due to improved moisture conditions in the soil. TNT uptake by crops was not influenced by the level of hay added because neither TNT nor its degradation products were detected in any aboveground crop organs. TNT was not detected in any of the 48 oat root samples analyzed, but $4 \mathrm{~A}-\mathrm{DNT}$ and $2 \mathrm{~A}-\mathrm{DNT}$ were detected in about $17 \%$ of the root samples. Concentrations of 4A-DNT (less than or equal to $5.79 \mathrm{mg} \mathrm{kg}^{-1}$ ) and 2A-DNT (less than or equal to $3.82 \mathrm{mg} \mathrm{kg}^{-1}$ ) were generally low, with the exception of one sample that contained $21.0 \mathrm{mg} \mathrm{kg}^{-1} 4 \mathrm{~A}-\mathrm{DNT}$ and $32.2 \mathrm{mg} \mathrm{kg}^{-1} 2 \mathrm{~A}-\mathrm{DNT}$. The presence of these compounds in root samples is not related to TNT concentrations, but is probably a vestige of ineffective root washing.

Evidence was found to indicate that soil manipulation and the addition of chopped hay may have reduced extractable TNT concentrations in the soils. Wide variations in TNT concentrations prevented development of conclusive evidence regarding reduction of extractable TNT in the soils at the study site. One possible explanation for the decrease in extractable TNT is sorption of TNT degradation products by soil and/or organic particles. TNT is degraded to nitroaromatic amines that can chemically bind to soil and/or organic particles. Mixing and manipulation of TNTcontaminated soils exposes TNT molecules to additional soil and organic particles, thus reducing the amount of extractable TNT in the soil. Initial sorption is high, but the rate decreases over time because fewer and fewer TNT molecules are available. Another potential explanation is that TNT is degraded by soil and/or rhizosphere microorganism activity and populations.

TNT and its degradation products (2A-DNT, 4A-DNT) were not detected (the limits of detection for the method used were $0.08 \mathrm{mg} \mathrm{kg}^{-1}$ for TNT, $0.2 \mathrm{mg} \mathrm{kg}^{-1}$ for $4 \mathrm{~A}-\mathrm{DNT}$, and $0.2 \mathrm{mg} \mathrm{kg}^{-1}$ for 2A-DNT) in aboveground portions of the existing vegetation or crops grown on TNT-contaminated soil at JAAP. Based upon the methods used, the uptake of TNT into plants should not be considered a major health hazard in the human food chain. However, consumption of plants grown on TNT-contaminated sites is not advised because the soil and roots may contain TNT, 4A-DNT, or 2A-DNT that may be toxic. 


\section{References}

Banwart, W.L., and J.J. Hassett, 1990, "Effects of Soil Amendments on Plant Tolerance and Extractable TNT from TNT-Contaminated Soils," in Agronomy Abstracts, American Society of Agronomy, Madison, Wis., p. 33.

Carns, B.A., 1994, personal communication, Biostatistician, Biological and Medical Research Division, Argonne National Laboratory, Argonne, Ill.

Cataldo, D.A., S.D. Harvey, and R.J. Fellows, 1993, The Environmental Behavior and Chemical Fate of Energetic Compounds (TNT, RDX, tetryl) in Soil and Plant Systems, PML-SA-22362, Pacific Northwest Laboratory, Richland, Wash.

Dames \& Moore, 1991, Final Phase I Technical Plan, Remedial Investigation/Feasibility Study Load-Assemble-Package (LAP) Area, Joliet Army Ammunition Plant, Joliet, Illinois, prepared for U.S. Army Toxic and Hazardous Materials Agency, Aberdeen Proving Ground, Md.

Doll, E.C., and R.E. Lucas, 1973, "Testing Soil for Potassium, Calcium, and Magnesium," in Soil Testing and Plant Analysis, L.M. Walsh and J.D. Becton (editors), Soil Science Society of America, Madison, Wis.

Folsom, B.L. Jr., J.C. Pennington, C.L. Teeter, M.R. Barton, and J.A. Bright, 1988, Effects of Soil pH and Treatment Level on Persistence and Plant Uptake of 2,4,6,-Trinitrotoluene, 1988 Final Report, EL-88-22, Environmental Laboratory, Waterways Experiment Station, Corps of Engineers, Vicksburg, Miss.

Hausenbuiller, R.L., 1972, Soil Science Principles and Practices, William C. Brown Company, Dubuque, Iowa.

Jenkins, T.F., 1990, Development of a Simplified Field Method for the Determination of TNT in Soil, Special Report 90-38. U.S. Army Cold Regions Research and Engineering Laboratory, Hanover, N.H.

Jones, J.B. Jr. (editor), 1980a, "Determination of Soil Water $\mathrm{pH}$," in Handbook on Reference Methods for Soil Testing (Revised Edition), Council on Soil Testing and Plant Analysis, University of Georgia, Athens, Ga., pp. 1-3.

Jones, J.B. Jr. (editor), 1980b, "Determination of Phosphorus by Bray 1 Extraction," in Handbook on Reference Methods for Soil Testing (Revised Edition), Council on Soil Testing and Plant Analysis, University of Georgia, Athens, Ga., pp. 42-46. 
Jones, J.B. Jr. (editor), 1980c, "Determination of Potassium, Calcium, Magnesium, and Sodium by Neutron Normal Ammonium Acetate Extraction," in Handbook on Reference Methods for Soil Testing (Revised Edition), Council on Soil Testing and Plant Analysis, University of Georgia, Athens, Ga., pp. 58-63.

Miller, Rupert G. Jr., 1966, Simultaneous Statistical Inference, McGraw-Hill, New York, N.Y.

Nelson, D.W., and L.E. Sommers, 1982, "Total Carbon, Organic Carbon, and Organic Matter," in Methods of Soil Analysis, Part 2, Second Edition, A.L. Page (editor), Agronomy, 9:539-580, American Society of Agronomy, Madison, Wis.

Palazzo, A.J., and D.C. Leggett, 1986, "Effect and Disposition of TNT in a Terrestrial Plant," Journal of Environmental Quality, 15:49-52.

Pennington, J.C., 1988, Soil Sorption and Plant Uptake of 2,4,6-Trinitrotoluene, 1988 Final Report, EL-88-12, Environmental Laboratory, Waterways Experiment Station, Corps of Engineers, Vicksburg, Miss.

Ray, A.A. (editor), 1982, SAS User's Guide: Statistics, 1982 Edition, Statistical Analysis System Institute Inc., Cary, N.C.

Rhoades, J.D., 1982, "Cation Exchange Capacity," in Methods of Soil Analysis, Part 2, Second Edition, A.L. Page (editor), Agronomy, 9:149-158, American Society of Agronomy, Madison, Wis.

Sobek, A.A., W.A. Schuller, J.R. Freeman, and R.M. Smith, 1978, Field and Laboratory Methods Applicable to Overburden and Minesoils, EPA-6QQ/2-78-054, U.S. Environmental Protection Agency Technology Series, Cincinnati, Ohio, pp. 41-42.

Sriharan, S., 1992, Survey of Munitions Contamination Literature, Center for Energy and Environmental Studies, Virginia State University, Petersburg, Va.

Technicon Industrial Systems, 1977, Technicon Auto Analyzer II Industrial Methods, Technicon Instruments Corp., Tarrytown, N.Y.

U.S. Environmental Protection Agency, 1986, SW 846 - Test Methods for Evaluating Solid Waste, Office of Solid Waste and Emergency Response, Washington, D.C. 


\section{Appendix}

Explosive Concentrations in Plot Soils for the Three TNT Areas with Means by Organic Material Addition on Nine Collection Dates 
TABLE A.1 Explosive Concentrations in Plot Soils for the High-TNT Area with Means by Organic Material Addition on 15 October 1993, before Organic Material Additions Were Made

\begin{tabular}{|c|c|c|c|c|c|c|c|c|}
\hline \multirow{2}{*}{$\begin{array}{l}\text { TNT } \\
\text { level }\end{array}$} & \multirow{2}{*}{$\begin{array}{c}\text { Organic } \\
\text { Material } \\
\text { Addition (\%) }\end{array}$} & \multirow[b]{2}{*}{ Crop } & \multirow{2}{*}{$\begin{array}{c}\text { Replicate } \\
\text { Number }\end{array}$} & \multirow{2}{*}{$\begin{array}{c}\text { Plot } \\
\text { Number }\end{array}$} & \multicolumn{4}{|c|}{ Explosive Concentration (mg kg-1) } \\
\hline & & & & & TNT & TNB & $\mathrm{RDX}$ & DNT \\
\hline High & 0 & Oat & 1 & 9 & 1440 & 2.2 & $<0.5^{\dagger}$ & $<0.5^{\dagger}$ \\
\hline High & 0 & Oat & 2 & 21 & 914 & 0.8 & $<0.5$ & $<0.5$ \\
\hline High & 0 & Oat & 3 & 2 & 470 & 0.6 & $<0.5$ & $<0.5$ \\
\hline High & 0 & Oat & 4 & 3 & 440 & 0.7 & $<0.5$ & $<0.5$ \\
\hline High & 0 & Ryegrass & 1 & 18 & 1630 & 2.4 & $<0.5$ & $<0.5$ \\
\hline High & 0 & Ryegrass & 2 & 19 & 3660 & 6.4 & $<0.5$ & $<0.5$ \\
\hline High & 0 & Ryegrass & 3 & 22 & 2360 & 3.3 & $<0.5$ & $<0.5$ \\
\hline \multirow[t]{2}{*}{ High } & 0 & Ryegrass & 4 & 13 & 2060 & 3.0 & $<0.5$ & $<0.5$ \\
\hline & & & Mean & & 1622 & 2.4 & $<0.5$ & $<0.5$ \\
\hline High & 1 & Oat & 1 & 24 & 502 & 0.6 & $<0.5$ & $<0.5$ \\
\hline High & 1 & Oat & 2 & 11 & 1170 & 1.9 & $<0.5$ & $<0.5$ \\
\hline High & 1 & Oat & 3 & 23 & 973 & 2.2 & $<0.5$ & $<0.5$ \\
\hline High & 1 & Oat & 4 & 17 & 2050 & 12.9 & $<0.5$ & $<0.5$ \\
\hline High & 1 & Ryegrass & 1 & 6 & 755 & 1.6 & $<0.5$ & $<0.5$ \\
\hline High & 1 & Ryegrass & 2 & 14 & 2670 & 3.8 & $<0.5$ & $<0.5$ \\
\hline High & 1 & Ryegrass & 3 & 15 & 986 & 1.4 & $<0.5$ & $<0.5$ \\
\hline \multirow[t]{2}{*}{ High } & 1 & Ryegrass & 4 & 20 & 338 & 0.3 & $<0.5$ & $<0.5$ \\
\hline & . & & Mean & & 1181 & 3.1 & $<0.5$ & $<0.5$ \\
\hline High & 2 & Oat & 1 & 7 & 389 & 0.4 & $<0.5$ & $<0.5$ \\
\hline High & 2 & Oat & 2 & 1 & 1380 & 2.5 & $<0.5$ & $<0.5$ \\
\hline High & 2 & Oat & 3 & 10 & 1720 & 2.3 & $<0.5$ & $<0.5$ \\
\hline High & 2 & Oat & 4 & 8 & 662 & 0.5 & $<0.5$ & $<0.5$ \\
\hline High & 2 & Ryegrass & 1 & 4 & 340 & $<0.3^{\dagger}$ & $<0.5$ & $<0.5$ \\
\hline High & 2 & Ryegrass & 2 & 12 & 1370 & 3.4 & $<0.5$ & $<0.5$ \\
\hline High & 2 & Ryegrass & 3 & 16 & 1910 & 3.2 & $<0.5$ & $<0.5$ \\
\hline \multirow[t]{2}{*}{ High } & 2 & Ryegrass & 4 & 5 & 1340 & 3.3 & $<0.5$ & $<0.5$ \\
\hline & & & Mean & & 1139 & 2.2 & $<0.5$ & $<0.5$ \\
\hline
\end{tabular}

t Detection Limit. 
TABLE A.2 Explosive Concentrations in Plot Soils for the Intermediate-TNT Area with Means by Organic Material Addition on 15 October 1993, before Organic Material Additions Were Made

\begin{tabular}{|c|c|c|c|c|c|c|c|c|}
\hline \multirow{2}{*}{$\begin{array}{l}\text { TNT } \\
\text { Level }\end{array}$} & \multirow{2}{*}{$\begin{array}{c}\text { Organic } \\
\text { Material } \\
\text { Addition (\%) }\end{array}$} & \multirow[b]{2}{*}{ Crop } & \multirow{2}{*}{$\begin{array}{c}\text { Replicate } \\
\text { Number }\end{array}$} & \multirow{2}{*}{$\begin{array}{c}\text { Plot } \\
\text { Number }\end{array}$} & \multicolumn{4}{|c|}{ Explosive Concentration (mg kg-1) } \\
\hline & & & & & TNT & TNB & $\mathrm{RDX}$ & DNT \\
\hline Intermediate & 0 & Oat & 1 & 41 & 72 & $<0.3^{\dagger}$ & $<0.5^{\dagger}$ & $<0.5^{\dagger}$ \\
\hline Intermediate & 0 & Oat & 2 & 32 & 170 & $<0.3$ & $<0.5$ & $<0.5$ \\
\hline Intermediate & 0 & Oat & 3 & 39 & 35 & $<0.3$ & $<0.5$ & $<0.5$ \\
\hline Intermediate & 0 & Oat & 4 & 25 & 185 & 1.3 & $<0.5$ & $<0.5$ \\
\hline Intermediate & 0 & Ryegrass & 1 & 26 & 274 & 0.4 & $<0.5$ & $<0.5$ \\
\hline Intermediate & 0 & Ryegrass & 2 & 46 & 48 & $<0.3$ & $<0.5$ & $<0.5$ \\
\hline Intermediate & 0 & Ryegrass & 3 & 37 & 258 & $<0.3$ & $<0.5$ & $<0.5$ \\
\hline \multirow[t]{2}{*}{ Intermediate } & 0 & Ryegrass & 4 & 33 & 363 & 1.5 & $<0.5$ & $<0.5$ \\
\hline & & & Mean & & 176 & 1.1 & $<0.5$ & $<0.5$ \\
\hline Intermediate & 1 & Oat & 1 & 28 & 334 & 0.4 & $<0.5$ & $<0.5$ \\
\hline Intermediate & 1 & Oat & 2 & 29 & 196 & 0.4 & $<0.5$ & $<0.5$ \\
\hline Intermediate & 1 & Oat & 3 & 31 & 116 & $<0.3$ & $<0.5$ & $<0.5$ \\
\hline Intermediate & 1 & Oat & 4 & 44 & 11 & 3.6 & $<0.5$ & $<0.5$ \\
\hline Intermediate & 1 & Ryegrass & 1 & 27 & 245 & 0.3 & $<0.5$ & $<0.5$ \\
\hline Intermediate & 1 & Ryegrass & 2 & 42 & 14 & 1.7 & $<0.5$ & $<0.5$ \\
\hline Intermediate & 1 & Ryegrass & 3 & 45 & 213 & $<0.3$ & $<0.5$ & $<0.5$ \\
\hline \multirow[t]{2}{*}{ Intermediate } & 1 & Ryegrass & 4 & 35 & 12 & $<0.3$ & $<0.5$ & $<0.5$ \\
\hline & . & & Mean & & 143 & 1.3 & $<0.5$ & $<0.5$ \\
\hline Intermediate & 2 & Oat & 1 & 30 & 107 & $<0.3$ & $<0.5$ & $<0.5$ \\
\hline Intermediate & 2 & Oat & 2 & 43 & 7 & $<0.3$ & $<0.5$ & $<0.5$ \\
\hline Intermediate & 2 & Oat & 3 & 40 & 11 & $<0.3$ & $<0.5$ & $<0.5$ \\
\hline Intermediate & 2 & Oat & 4 & 34 & 34 & $<0.3$ & $<0.5$ & $<0.5$ \\
\hline Intermediate & 2 & Ryegrass & 1 & 48 & 18 & $<0.3$ & $<0.5$ & $<0.5$ \\
\hline Intermediate & 2 & Ryegrass & 2 & 36 & 125 & $<0.3$ & $<0.5$ & $<0.5$ \\
\hline Intermediate & 2 & Ryegrass & 3 & 38 & 26 & $<0.3$ & $<0.5$ & $<0.5$ \\
\hline \multirow[t]{2}{*}{ Intermediate } & 2 & Ryegrass & 4 & 47 & 15 & $<0.3$ & $<0.5$ & $<0.5$ \\
\hline & & & Mean & & 34 & $<0.3$ & $<0.5$ & $<0.5$ \\
\hline
\end{tabular}

t Detection Limit. 
TABLE A.3 Explosive Concentrations in Plot Soils for the Zero-TNT Area with Means by Organic Material Addition on 15 October 1993, before Organic Material Additions Were Made

\begin{tabular}{|c|c|c|c|c|c|c|c|c|}
\hline \multirow{2}{*}{$\begin{array}{l}\text { TNT } \\
\text { Level }\end{array}$} & \multirow{2}{*}{$\begin{array}{c}\text { Organic } \\
\text { Material } \\
\text { Addition (\%) }\end{array}$} & \multirow[b]{2}{*}{ Crop } & \multirow{2}{*}{$\begin{array}{l}\text { Replicate } \\
\text { Number }\end{array}$} & \multirow{2}{*}{$\begin{array}{c}\text { Plot } \\
\text { Number }\end{array}$} & \multicolumn{4}{|c|}{ Explosive Concentration (mg kg-1) } \\
\hline & & & & & TNT & TNB & $\mathrm{RDX}$ & DNT \\
\hline Zero & 0 & Oat & 1 & 58 & $<0.5^{\dagger}$ & $<0.3^{\dagger}$ & $<0.5^{t}$ & $<0.5^{\dagger}$ \\
\hline Zero & 0 & Oat & 2 & 65 & $<0.5$ & $<0.3^{\circ}$ & $<0.5$ & $<0.5$ \\
\hline Zero & 0 & Oat & 3 & 52 & $<0.5$ & $<0.3$ & $<0.5$ & $<0.5$ \\
\hline Zero & 0 & Oat & 4 & 55 & $<0.5$ & $<0.3$ & $<0.5$ & $<0.5$ \\
\hline Zero & 0 & Ryegrass & 1 & 53 & $<0.5$ & $<0.3$ & $<0.5$ & $<0.5$ \\
\hline Zero & 0 & Ryegrass & 2 & 57 & $<0.5$ & $<0.3$ & $<0.5$ & $<0.5$ \\
\hline Zero & 0 & Ryegrass & 3 & 64 & $<0.5$ & $<0.3$ & $<0.5$ & $<0.5$ \\
\hline \multirow[t]{2}{*}{ Zero } & 0 & Ryegrass & 4 & 56 & $<0.5$ & $<0.3$ & $<0.5$ & $<0.5$ \\
\hline & & & Mean & & $<0.5$ & $<0.3$ & $<0.5$ & $<0.5$ \\
\hline Zero & 1 & Oat & 1 & 61 & $<0.5$ & $<0.3$ & $<0.5$ & $<0.5$ \\
\hline Zero & 1 & Oat & 2 & 68 & $<0.5$ & $<0.3$ & $<0.5$ & $<0.5$ \\
\hline Zero & 1 & Oat & 3 & 67 & $<0.5$ & $<0.3$ & $<0.5$ & $<0.5$ \\
\hline Zero & 1 & Oat & 4 & 50 & $<0.5$ & $<0.3$ & $<0.5$ & $<0.5$ \\
\hline Zero & 1 & Ryegrass & 1 & 49 & $<0.5$ & $<0.3$ & $<0.5$ & $<0.5$ \\
\hline Zero & 1 & Ryegrass & 2 & 70 & $<0.5$ & $<0.3$ & $<0.5$ & $<0.5$ \\
\hline Zero & 1 & Ryegrass & 3 & 69 & $<0.5$ & $<0.3$ & $<0.5$ & $<0.5$ \\
\hline \multirow[t]{2}{*}{ Zero } & 1 & Ryegrass & 4 & 71 & $<0.5$ & $<0.3$ & $<0.5$ & $<0.5$ \\
\hline & & & Mean & & $<0.5$ & $<0.3$ & $<0.5$ & $<0.5$ \\
\hline Zero & 2 & Oat & 1 & 66 & $<0.5$ & $<0.3$ & $<0.5$ & $<0.5$ \\
\hline Zero & 2 & Oat & 2 & 51 & $<0.5$ & $<0.3$ & $<0.5$ & $<0.5$ \\
\hline Zero & 2 & Oat & 3 & 59 & $<0.5$ & $<0.3$ & $<0.5$ & $<0.5$ \\
\hline Zero & 2 & Oat & 4 & 60 & $<0.5$ & $<0.3$ & $<0.5$ & $<0.5$ \\
\hline Zero & 2 & Ryegrass & 1 & 54 & $<0.5$ & $<0.3$ & $<0.5$ & $<0.5$ \\
\hline Zero & 2 & Ryegrass & 2 & 62 & $<0.5$ & $<0.3$ & $<0.5$ & $<0.5$ \\
\hline Zero & 2 & Ryegrass & 3 & 63 & $<0.5$ & $<0.3$ & $<0.5$ & $<0.5$ \\
\hline \multirow[t]{2}{*}{ Zero } & 2 & Ryegrass & 4 & 72 & $<0.5$ & $<0.3$ & $<0.5$ & $<0.5$ \\
\hline & & & Mean & & $<0.5$ & $<0.3$ & $<0.5$ & $<0.5$ \\
\hline
\end{tabular}

† Detection Limit. 
TABLE A.4 Explosive Concentrations in Plot Soils for the High-TNT Area with Means by Organic Material Addition on 28 October 1993, Immediately Following Addition of Organic Material

\begin{tabular}{|c|c|c|c|c|c|c|}
\hline \multirow{2}{*}{$\begin{array}{l}\text { TNT } \\
\text { Level }\end{array}$} & \multirow{2}{*}{$\begin{array}{c}\text { Organic } \\
\text { Material } \\
\text { Addition (\%) }\end{array}$} & \multirow[b]{2}{*}{ Crop } & \multirow{2}{*}{$\begin{array}{l}\text { Replicate } \\
\text { Number }\end{array}$} & \multirow{2}{*}{$\begin{array}{c}\text { Plot } \\
\text { Number }\end{array}$} & \multicolumn{2}{|c|}{$\begin{array}{c}\text { Explosive Concentration } \\
\left(\mathrm{mg} \mathrm{kg}^{-1}\right)\end{array}$} \\
\hline & & & & & TNT & TNB \\
\hline High & 0 & Oat & 1 & 9 & 874 & 2.0 \\
\hline High & 0 & Oat & 2 & 21 & 402 & 0.8 \\
\hline High & 0 & Oat & 3 & 2 & 362 & 1.3 \\
\hline High & 0 & Oat & 4 & 3 & 1110 & 2.1 \\
\hline High & 0 & Ryegrass & 1 & 18 & 2330 & 3.5 \\
\hline High & 0 & Ryegrass & 2 & 19 & 2330 & 3.6 \\
\hline High & 0 & Ryegrass & 3 & 22 & 855 & 1.7 \\
\hline \multirow[t]{2}{*}{ High } & 0 & Ryegrass & 4 & 13 & 1840 & 5.0 \\
\hline & & & Mean & & 1263 & 2.5 \\
\hline High & 1 & Oat & 1 & 24 & 585 & 1.4 \\
\hline High & 1 & Oat & 2 & 11 & 401 & 2.5 \\
\hline High & 1 & Oat & 3 & 23 & 1390 & 2.8 \\
\hline High & 1 & Oat & 4 & 17 & 1300 & 1.8 \\
\hline High & 1 & Ryegrass & 1 & 6 & 292 & 1.1 \\
\hline High & 1 & Ryegrass & 2 & 14 & 2690 & 3.6 \\
\hline High & 1 & Ryegrass & 3 & 15 & 1440 & 2.5 \\
\hline \multirow[t]{2}{*}{ High } & 1 & Ryegrass & 4 & 20 & 2220 & 3.1 \\
\hline & & & Mean & & 1290 & 2.4 \\
\hline High & 2 & Oat & 1 & 7 & 252 & 0.6 \\
\hline High & 2 & Oat & 2 & 1 & 2340 & 4.1 \\
\hline High & 2 & Oat & 3 & 10 & 485 & 2.1 \\
\hline High & 2 & Oat & 4 & 8 & 453 & 1.4 \\
\hline High & 2 & Ryegrass & 1 & 4 & 72 & 0.4 \\
\hline High & 2 & Ryegrass & 2 & 12 & 968 & 1.6 \\
\hline High & 2 & Ryegrass & 3 & 16 & 1440 & 2.1 \\
\hline \multirow[t]{2}{*}{ High } & 2 & Ryegrass & 4 & 5 & 453 & 1.3 \\
\hline & & & Mean & & 808 & 1.7 \\
\hline
\end{tabular}


TABLE A.5 Explosive Concentrations in Plot Soils for the Intermediate-TNT Area with Means by Organic Material Addition on 28 October 1993, Immediately Following Addition of Organic Material

\begin{tabular}{|c|c|c|c|c|c|c|}
\hline \multirow{2}{*}{$\begin{array}{l}\text { TNT } \\
\text { Level }\end{array}$} & \multirow{2}{*}{$\begin{array}{c}\text { Organic } \\
\text { Material } \\
\text { Addition (\%) }\end{array}$} & \multirow[b]{2}{*}{ Crop } & \multirow{2}{*}{$\begin{array}{l}\text { Replicate } \\
\text { Number }\end{array}$} & \multirow{2}{*}{$\begin{array}{l}\text { Plot } \\
\text { Number }\end{array}$} & \multicolumn{2}{|c|}{$\begin{array}{l}\text { Explosive Concentration } \\
\qquad\left(\mathrm{mg} \mathrm{kg}^{-1}\right)\end{array}$} \\
\hline & & & & & TNT & TNB \\
\hline Intermediate & 0 & Oat & 1 & 41 & 113 & $<0.3^{\dagger}$ \\
\hline Intermediate & 0 & Oat & 2 & 32 & 142 & 0.5 \\
\hline Intermediate & 0 & Oat & 3 & 39 & 10 & 0.6 \\
\hline Intermediate & 0 & Oat & 4 & 25 & 344 & 1.8 \\
\hline Intermediate & 0 & Ryegrass & 1 & 26 & 281 & 1.4 \\
\hline Intermediate & 0 & Ryegrass & 2 & 46 & 1 & $<0.3$ \\
\hline Intermediate & 0 & Ryegrass & 3 & 37 & 262 & 0.8 \\
\hline \multirow[t]{2}{*}{ Intermediate } & 0 & Ryegrass & 4 & 33 & 211 & 0.8 \\
\hline & & & Mean & & 170 & 1.0 \\
\hline Intermediate & 1 & Oat & 1 & 28 & 415 & 2.0 \\
\hline Intermediate & 1 & Oat & 2 & 29 & 76 & 0.5 \\
\hline Intermediate & 1 & Oat & 3 & 31 & 28 & $<0.3$ \\
\hline Intermediate & 1 & Oat & 4 & 44 & 2 & 0.5 \\
\hline Intermediate & 1 & Ryegrass & 1 & 27 & 525 & 3.1 \\
\hline Intermediate & 1 & Ryegrass & 2 & 42 & 2 & $<0.3$ \\
\hline Intermediate & 1 & Ryegrass & 3 & 45 & 127 & $<0.3$ \\
\hline Intermediate & 1 & Ryegrass & 4 & 35 & 28 & $<0.3$ \\
\hline . & & & Mean & & 150 & 1.5 \\
\hline Intermediate & 2 & Oat & 1 & 30 & 70 & $<0.3$ \\
\hline Intermediate & 2 & Oat & 2 & 43 & 87 & $<0.3$ \\
\hline Intermediate & 2 & Oat & 3 & 40 & 20 & $<0.3$ \\
\hline Intermediate & 2 & Oat & 4 & 34 & 100 & 0.4 \\
\hline Intermediate & 2 & Ryegrass & 1 & 48 & 4 & 0.4 \\
\hline Intermediate & 2 & Ryegrass & 2 & 36 & 11 & $<0.3$ \\
\hline Intermediate & 2 & Ryegrass & 3 & 38 & 3 & $<0.3$ \\
\hline \multirow[t]{2}{*}{ Intermediate } & 2 & Ryegrass & 4 & 47 & 1 & 0.4 \\
\hline & & & Mean & & 32 & 0.4 \\
\hline
\end{tabular}

† Detection Limit. 
TABLE A.6 Explosive Concentrations in Plot Soils for the Zero-TNT Area with Means by Organic Material Addition on 28 October 1993, Immediately Following Addition of Organic Material

\begin{tabular}{|c|c|c|c|c|c|c|}
\hline \multirow{2}{*}{$\begin{array}{l}\text { TNT } \\
\text { Level }\end{array}$} & \multirow{2}{*}{$\begin{array}{c}\text { Organic } \\
\text { Material } \\
\text { Addition (\%) }\end{array}$} & \multirow[b]{2}{*}{ Crop } & \multirow{2}{*}{$\begin{array}{l}\text { Replicate } \\
\text { Number }\end{array}$} & \multirow{2}{*}{$\begin{array}{l}\text { Plot } \\
\text { Number }\end{array}$} & \multicolumn{2}{|c|}{$\begin{array}{c}\text { Explosive Concentration } \\
\left(\mathrm{mg} \mathrm{kg}^{-1}\right)\end{array}$} \\
\hline & & & & & TNT & TNB \\
\hline Zero & 0 & Oat & 1 & 58 & $<0.5^{\dagger}$ & $<0.3^{\dagger}$ \\
\hline Zero & 0 & Oat & 2 & 65 & $<0.5$ & $<0.3$ \\
\hline Zero & 0 & Oat & 3 & 52 & $<0.5$ & $<0.3$ \\
\hline Zero & 0 & Oat & 4 & 55 & $<0.5$ & $<0.3$ \\
\hline Zero & 0 & Ryegrass & 1 & 53 & $<0.5$ & $<0.3$ \\
\hline Zero & 0 & Ryegrass & 2 & 57 & $<0.5$ & $<0.3$ \\
\hline Zero & 0 & Ryegrass & 3 & 64 & $<0.5$ & $<0.3$ \\
\hline \multirow[t]{2}{*}{ Zero } & 0 & Ryegrass & 4 & 56 & $<0.5$ & $<0.3$ \\
\hline & & & Mean & & $<0.5$ & $<0.3$ \\
\hline Zero & 1 & Oat & 1 & 61 & $<0.5$ & $<0.3$ \\
\hline Zero & 1 & Oat & 2 & 68 & $<0.5$ & $<0.3$ \\
\hline Zero & 1 & Oat & 3 & 67 & $<0.5$ & $<0.3$ \\
\hline Zero & 1 & Oat & 4 & 50 & $<0.5$ & $<0.3$ \\
\hline Zero & 1 & Ryegrass & 1 & 49 & $<0.5$ & $<0.3$ \\
\hline Zero & 1 & Ryegrass & 2 & 70 & $<0.5$ & $<0.3$ \\
\hline Zero & 1 & Ryegrass & 3 & 69 & $<0.5$ & $<0.3$ \\
\hline \multirow[t]{2}{*}{ Zero } & 1 & Ryegrass & 4 & 71 & $<0.5$ & $<0.3$ \\
\hline & & & Mean & & $<0.5$ & $<0.3$ \\
\hline Zero & 2 & Oat & 1 & 66 & $<0.5$ & $<0.3$ \\
\hline Zero & 2 & Oat & 2 & 51 & $<0.5$ & $<0.3$ \\
\hline Zero & 2 & Oat & 3 & 59 & $<0.5$ & $<0.3$ \\
\hline Zero & 2 & Oat & 4 & 60 & $<0.5$ & $<0.3$ \\
\hline Zero & 2 & Ryegrass & 1 & 54 & $<0.5$ & $<0.3$ \\
\hline Zero & 2 & Ryegrass & 2 & 62 & $<0.5$ & $<0.3$ \\
\hline Zero & 2 & Ryegrass & 3 & 63 & $<0.5$ & $<0.3$ \\
\hline \multirow[t]{2}{*}{ Zero } & 2 & Ryegrass & 4 & 72 & $<0.5$ & $<0.3$ \\
\hline & & & Mean & & $<0.5$ & $<0.3$ \\
\hline
\end{tabular}

$\dagger$ Detection Limit.

NOTE: Additional Soil collection were made from the zero TNT area, but all explosive values were below

detection limits. 
TABLE A.7 Explosive Concentrations in Plot Soils for the High-TNT Area with Means by Organic Material Addition on 10 December 1993, 43 Days After Addition of Organic Material

\begin{tabular}{|c|c|c|c|c|c|c|}
\hline \multirow{2}{*}{$\begin{array}{l}\text { TNT } \\
\text { Level }\end{array}$} & \multirow{2}{*}{$\begin{array}{c}\text { Organic } \\
\text { Material } \\
\text { Addition (\%) }\end{array}$} & \multirow[b]{2}{*}{ Crop } & \multirow{2}{*}{$\begin{array}{l}\text { Replicate } \\
\text { Number }\end{array}$} & \multirow{2}{*}{$\begin{array}{l}\text { Plot } \\
\text { Number }\end{array}$} & \multicolumn{2}{|c|}{$\begin{array}{c}\text { Explosive Concentration } \\
\left(\mathrm{mg} \mathrm{kg} \mathrm{k}^{-1}\right)\end{array}$} \\
\hline & & & & & TNT & TNB \\
\hline High & 0 & Oat & 1 & 9 & 755 & 1.7 \\
\hline High & 0 & Oat & 2 & 21 & 398 & 0.9 \\
\hline High & 0 & Oat & 3 & 2 & 736 & 1.9 \\
\hline High & 0 & Oat & 4 & 3 & 183 & 0.7 \\
\hline High & 0 & Ryegrass & 1 & 18 & 1630 & 2.3 \\
\hline High & 0 & Ryegrass & 2 & 19 & 797 & 1.5 \\
\hline High & 0 & Ryegrass & 3 & 22 & 1090 & 2.3 \\
\hline \multirow[t]{2}{*}{ High } & 0 & Ryegrass & 4 & 13 & 1540 & 2.4 \\
\hline & & & Mean & & 891 & 1.7 \\
\hline High & 1 & Oat & 1 & 24 & 426 & 0.5 \\
\hline High & 1 & Oat & 2 & 11 & 1090 & 1.9 \\
\hline High & 1 & Oat & 3 & 23 & 655 & 1.2 \\
\hline High & 1 & Oat & 4 & 17 & 972 & 2.4 \\
\hline High & 1 & Ryegrass & 1 & 6 & 254 & 0.7 \\
\hline High & 1 & Ryegrass & 2 & 14 & 2470 & 3.4 \\
\hline High & 1 & Ryegrass & 3 & 15 & 1240 & 2.3 \\
\hline \multirow[t]{2}{*}{ High } & 1 & Ryegrass & 4 & 20 & 388 & 0.7 \\
\hline & & & Mean & & 937 & 1.6 \\
\hline High & 2 & Oat & 1 & 7 & 95 & $<0.3^{\dagger}$ \\
\hline High & 2 & Oat & 2 & 1 & 990 & 2.2 \\
\hline High & 2 & Oat & 3 & 10 & 399 & 1.3 \\
\hline High & 2 & Oat & 4 & 8 & 529 & 0.5 \\
\hline High & 2 & Ryegrass & 1 & 4 & 120 & $<0.3$ \\
\hline High & 2 & Ryegrass & 2 & 12 & 1170 & 1.5 \\
\hline High & 2 & Ryegrass & 3 & 16 & 2290 & 3.4 \\
\hline \multirow[t]{2}{*}{ High } & 2 & Ryegrass & 4 & 5 & 345 & 1.1 \\
\hline & & & Mean & & 742 & 1.7 \\
\hline
\end{tabular}

† Detection Limit. 
TABLE A.8 Explosive Concentrations in Plot Soils for the Intermediate-TNT Area with Means by Organic Material Addition on 10 December 1993, 43 Days After Addition of Organic Material

\begin{tabular}{|c|c|c|c|c|c|c|}
\hline \multirow{2}{*}{$\begin{array}{l}\text { TNT } \\
\text { Level }\end{array}$} & \multirow{2}{*}{$\begin{array}{c}\text { Organic } \\
\text { Material } \\
\text { Addition (\%) }\end{array}$} & \multirow[b]{2}{*}{ Crop } & \multirow{2}{*}{$\begin{array}{l}\text { Replicate } \\
\text { Number }\end{array}$} & \multirow{2}{*}{$\begin{array}{l}\text { Plot } \\
\text { Number }\end{array}$} & \multicolumn{2}{|c|}{$\begin{array}{c}\text { Explosive Concentration } \\
\left(\mathrm{mg} \mathrm{kg}^{-1}\right)\end{array}$} \\
\hline & & & & & TNT & TNB \\
\hline Intermediate & 0 & Oat & 1 & 41 & 107 & $<0.3^{\dagger}$ \\
\hline Intermediate & 0 & Oat & 2 & 32 & 237 & 0.8 \\
\hline Intermediate & 0 & Oat & 3 & 39 & 6 & $<0.3$ \\
\hline Intermediate & 0 & Oat & 4 & 25 & 167 & 1.0 \\
\hline Intermediate & 0 & Ryegrass & 1 & 26 & 335 & 2.9 \\
\hline Intermediate & 0 & Ryegrass & 2 & 46 & 3 & $<0.3$ \\
\hline Intermediate & 0 & Ryegrass & 3 & 37 & 230 & 0.8 \\
\hline \multirow[t]{2}{*}{ Intermediate } & 0 & Ryegrass & 4 & 33 & 122 & 0.6 \\
\hline & & & Mean & & 151 & 1.2 \\
\hline Intermediate & 1 & Oat & 1 & 28 & 3950 & 11.3 \\
\hline Intermediate & 1 & Oat & 2 & 29 & 46 & $<0.3$ \\
\hline Intermediate & 1 & Oat & 3 & 31 & 18 & $<0.3$ \\
\hline Intermediate & 1 & Oat & 4 & 44 & 1 & $<0.3$ \\
\hline Intermediate & 1 & Ryegrass & 1 & 27 & 444 & 2.1 \\
\hline Intermediate & 1 & Ryegrass & 2 & 42 & 5 & $<0.3$ \\
\hline Intermediate & 1 & Ryegrass & 3 & 45 & 114 & 0.7 \\
\hline \multirow{2}{*}{ Intermediate } & 1 & Ryegrass & 4 & 35 & 6 & $<0.3$ \\
\hline & & & Mean & & 573 & 4.7 \\
\hline Intermediate & 2 & Oat & 1 & 30 & 41 & $<0.3$ \\
\hline Intermediate & 2 & Oat & 2 & 43 & 45 & $<0.3$ \\
\hline Intermediate & 2 & Oat & 3 & 40 & 1 & $<0.3$ \\
\hline Intermediate & 2 & Oat & 4 & 34 & 99 & 1.1 \\
\hline Intermediate & 2 & Ryegrass & 1 & 48 & 2 & $<0.3$ \\
\hline Intermediate & 2 & Ryegrass & 2 & 36 & 17 & $<0.3$ \\
\hline Intermediate & 2 & Ryegrass & 3 & 38 & 5 & $<0.3$ \\
\hline \multirow[t]{2}{*}{ Intermediate } & 2 & Ryegrass & 4 & 47 & $<0.5^{\dagger}$ & $<0.3$ \\
\hline & & & Mean & & 28 & 1.1 \\
\hline
\end{tabular}

†etection Limit. 
TABLE A.9 Explosive Concentrations in Plot Soils for the High-TNT Area with Means by Organic Material Addition on 17 February 1994, 112 Days After Addition of Organic Material

\begin{tabular}{|c|c|c|c|c|c|c|c|c|}
\hline \multirow{2}{*}{$\begin{array}{l}\text { TNT } \\
\text { Level }\end{array}$} & \multirow{2}{*}{$\begin{array}{c}\text { Organic } \\
\text { Material } \\
\text { Addition (\%) }\end{array}$} & \multirow[b]{2}{*}{ Crop } & \multirow{2}{*}{$\begin{array}{l}\text { Replicate } \\
\text { Number }\end{array}$} & \multirow{2}{*}{$\begin{array}{c}\text { Plot } \\
\text { Number }\end{array}$} & \multicolumn{4}{|c|}{ Explosive Concentration (mg kg${ }^{-1}$ ) } \\
\hline & & & & & TNT & TNB & 4A-DNT & 2A-DNT \\
\hline High & 0 & Oat & 1 & 9 & 679 & 2.4 & 14.1 & 13.8 \\
\hline High & 0 & Oat & 2 & 21 & 322 & 0.4 & 13.7 & 14.1 \\
\hline High & 0 & Oat & 3 & 2 & 386 & 1.2 & 9.4 & 9.9 \\
\hline High & 0 & Oat & 4 & 3 & 179 & 0.7 & 9.8 & 9.0 \\
\hline High & 0 & Ryegrass & 1 & 18 & 1240 & 2.2 & 20.6 & 18.2 \\
\hline High & 0 & Ryegrass & 2 & 19 & 1110 & 2.0 & 17.9 & 15.3 \\
\hline High & 0 & Ryegrass & 3 & 22 & 1580 & 2.3 & 13.2 & 14.3 \\
\hline \multirow[t]{2}{*}{ High } & 0 & Ryegrass & 4 & 13 & 3210 & 2.6 & 29.2 & 29.8 \\
\hline & & & Mean & & 1088 & 1.7 & 16.0 & 15.6 \\
\hline High & 1 & Oat & 1 & 24 & 489 & 1.1 & 12.3 & 15.3 \\
\hline High & 1 & Oat & 2 & 11 & 1880 & 1.3 & 58.6 & 41.2 \\
\hline High & 1 & Oat & 3 & 23 & 215 & 0.7 & 18.9 & 15.3 \\
\hline High & 1 & Oat & 4 & 17 & 958 & 1.4 & 31.9 & 24.4 \\
\hline High & 1 & Ryegrass & 1 & 6 & 185 & 1.0 & 22.9 & 16.3 \\
\hline High & 1 & Ryegrass & 2 & 14 & 4410 & 5.0 & $<0.2^{f}$ & $<0.2^{t}$ \\
\hline High & 1 & Ryegrass & 3 & 15 & 905 & 1.6 & 20.0 & 16.9 \\
\hline \multirow[t]{2}{*}{ High } & 1 & Ryegrass & 4 & 20 & 357 & 0.9 & 16.5 & 13.4 \\
\hline & . & & Mean & & 1175 & 1.6 & 25.9 & 20.4 \\
\hline High & 2 & Oat & 1 & 7 & 173 & 0.4 & 18.5 & 13.9 \\
\hline High & 2 & Oat & 2 & 1 & 1440 & 2.2 & 103.0 & 58.0 \\
\hline High & 2 & Oat & 3 & 10 & 393 & 0.9 & 19.4 & 14.1 \\
\hline High & 2 & Oat & 4 & 8 & 199 & 0.5 & 29.9 & 20.3 \\
\hline High & 2 & Ryegrass & 1 & 4 & 20 & $<0.3^{\dagger}$ & 10.8 & 8.8 \\
\hline High & 2 & Ryegrass & 2 & 12 & 1010 & 1.5 & 31.4 & 21.3 \\
\hline High & 2 & Ryegrass & 3 & 16 & 1970 & 1.7 & 30.1 & 25.6 \\
\hline \multirow[t]{2}{*}{ High } & 2 & Ryegrass & 4 & 5 & 298 & 1.4 & 37.0 & 24.0 \\
\hline & & & Mean & & 688 & 1.2 & 35.0 & 23.3 \\
\hline
\end{tabular}

† Detection Limit. 
TABLE A.10 Explosive Concentrations in Plot Soils for the Intermediate-TNT Area with Means by Organic Material Addition on 17 February 1994, 112 Days After Addition of Organic Material

\begin{tabular}{|c|c|c|c|c|c|c|c|c|}
\hline \multirow{2}{*}{$\begin{array}{l}\text { TNT } \\
\text { Level }\end{array}$} & \multirow{2}{*}{$\begin{array}{c}\text { Organic } \\
\text { Material } \\
\text { Addition (\%) }\end{array}$} & \multirow[b]{2}{*}{ Crop } & \multirow{2}{*}{$\begin{array}{c}\text { Replicate } \\
\text { Number }\end{array}$} & \multirow{2}{*}{$\begin{array}{c}\text { Plot } \\
\text { Number }\end{array}$} & \multicolumn{4}{|c|}{ Explosive Concentration $\left(\mathrm{mg} \mathrm{kg}^{-1}\right)$} \\
\hline & & & & & TNT & TNB & 4A-DNT & 2A-DNT \\
\hline Intermediate & 0 & Oat & 1 & 41 & 148 & 0.8 & 10.7 & 8.6 \\
\hline Intermediate & 0 & Oat & 2 & 32 & 56 & 0.5 & 10.2 & 8.7 \\
\hline Intermediate & 0 & Oat & 3 & 39 & 5 & $<0.3^{\dagger}$ & 4.8 & 2.7 \\
\hline Intermediate & 0 & Oat & 4 & 25 & 171 & 1.0 & 6.6 & 10.3 \\
\hline Intermediate & 0 & Ryegrass & 1 & 26 & 160 & 0.8 & 10.9 & 8.9 \\
\hline Intermediate & 0 & Ryegrass & 2 & 46 & 1 & $<0.3$ & 2.0 & 1.1 \\
\hline Intermediate & 0 & Ryegrass & 3 & 37 & 362 & 1.0 & 30.0 & 9.1 \\
\hline \multirow[t]{2}{*}{ Intermediate } & 0 & Ryegrass & 4 & 33 & 162 & 0.7 & 8.4 & 7.1 \\
\hline & & & Mean & & 133 & 0.8 & 10.5 & 7.1 \\
\hline Intermediate & 1 & Oat & 1 & 28 & 240 & 1.0 & 15.1 & 11.1 \\
\hline Intermediate & 1 & Oat & 2 & 29 & 49 & $<0.3$ & 4.5 & 2.6 \\
\hline Intermediate & 1 & Oat & 3 & 31 & 10 & $<0.3$ & 4.4 & 3.5 \\
\hline Intermediate & 1 & Oat & 4 & 44 & 2 & $<0.3$ & 0.9 & 1.5 \\
\hline Intermediate & 1 & Ryegrass & 1 & 27 & 326 & 1.4 & 13.5 & 8.8 \\
\hline Intermediate & 1 & Ryegrass & 2 & 42 & 1 & $<0.3$ & 1.1 & 1.4 \\
\hline Intermediate & 1 & Ryegrass & 3 & 45 & 66 & 0.7 & 14.2 & 8.3 \\
\hline \multirow[t]{2}{*}{ Intermediate } & 1 & Ryegrass & 4 & 35 & 19 & 0.8 & 3.0 & 2.0 \\
\hline & . & & Mean & & 89 & 1.0 & 7.1 & 4.9 \\
\hline Intermediate & 2 & Oat & 1 & 30 & 18 & $<0.3$ & 9.5 & 6.4 \\
\hline Intermediate & 2 & Oat & 2 & 43 & 12 & $<0.3$ & 0.6 & 5.0 \\
\hline Intermediate & 2 & Oat & 3 & 40 & 3 & $<0.3$ & 0.9 & 1.4 \\
\hline Intermediate & 2 & Oat & 4 & 34 & 70 & 0.4 & 8.5 & 4.8 \\
\hline Intermediate & 2 & Ryegrass & 1 & 48 & 2 & $<0.3$ & 0.8 & 2.4 \\
\hline Intermediate & 2 & Ryegrass & 2 & 36 & 19 & $<0.3$ & 4.3 & 3.8 \\
\hline Intermediate & 2 & Ryegrass & 3 & 38 & 20 & $<0.3$ & 3.0 & 1.4 \\
\hline \multirow[t]{2}{*}{ Intermediate } & 2 & Ryegrass & 4 & 47 & 25 & $<0.3$ & $<0.2^{\dagger}$ & 1.9 \\
\hline & & & Mean & & 21 & 0.4 & 3.0 & 3.0 \\
\hline
\end{tabular}

† Detection Limit. 
TABLE A.11 Explosive Concentrations in Plot Soils for the High-TNT Area with Means by Organic Material Addition on 22 March 1994, 145 Days After Addition of Organic Material

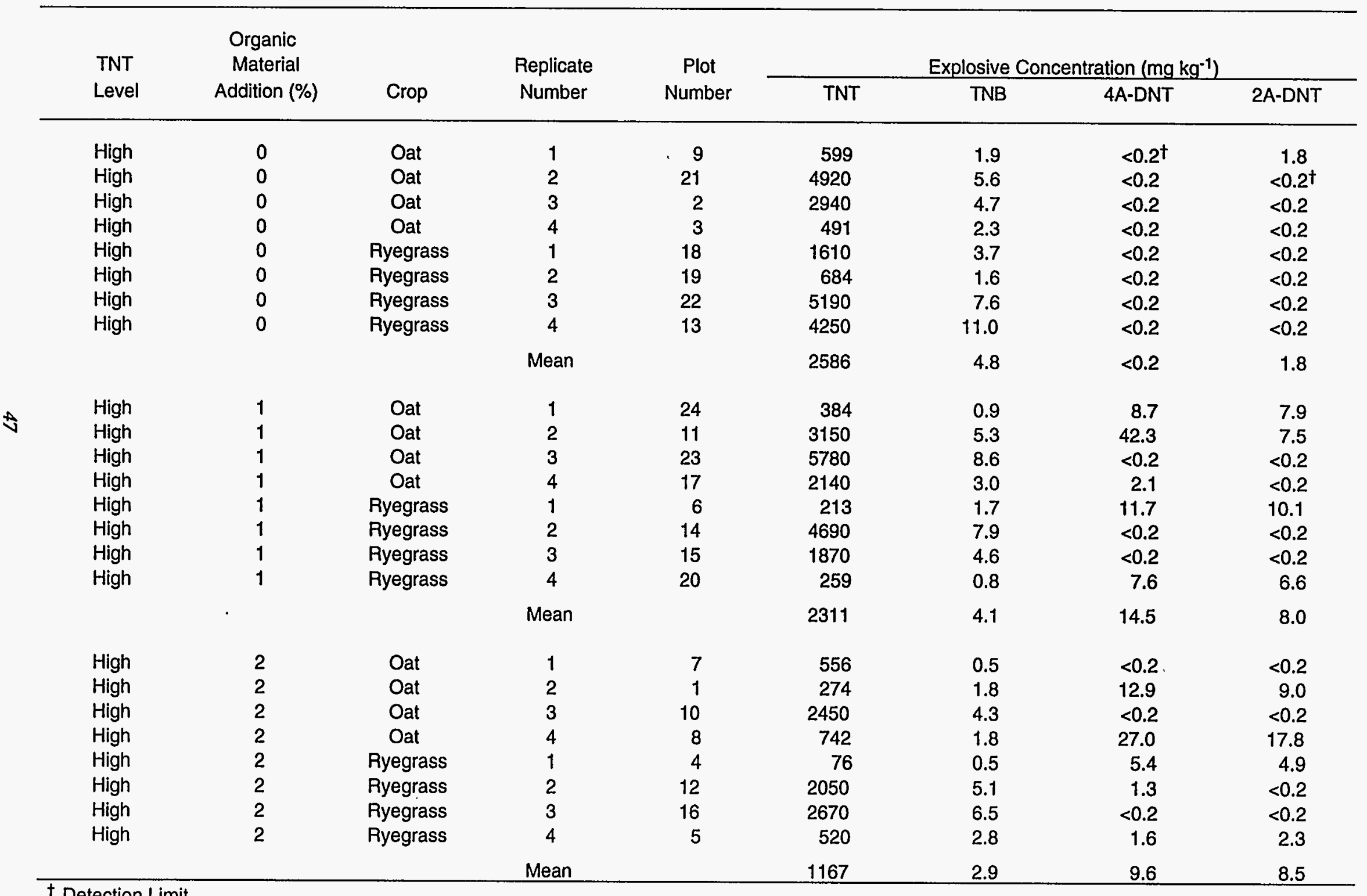

† Detection Limit. 
TABLE A.12 Explosive Concentrations in Plot Soils for the Intermediate-TNT Area with Means by Organic Material Addition on 22 March 1994, 145 Days After Addition of Organic Material

\begin{tabular}{|c|c|c|c|c|c|c|c|c|}
\hline \multirow{2}{*}{$\begin{array}{l}\text { TNT } \\
\text { Level }\end{array}$} & \multirow{2}{*}{$\begin{array}{l}\text { Organic } \\
\text { Material } \\
\text { Addition }\end{array}$} & \multirow[b]{2}{*}{ Crop } & \multirow{2}{*}{$\begin{array}{l}\text { Replicate } \\
\text { Number }\end{array}$} & \multirow{2}{*}{$\begin{array}{c}\text { Plot } \\
\text { Number }\end{array}$} & \multicolumn{4}{|c|}{ Explosive Concentration (mg $\mathrm{kg}^{-1}$ ) } \\
\hline & & & & & TNT & TNB & 4A-DNT & 2A-DNT \\
\hline Intermediate & 0 & Oat & 1 & 41 & 113 & $<0.3^{\dagger}$ & 10.6 & 7.6 \\
\hline Intermediate & 0 & Oat & 2 & 32 & 45 & $<0.3$ & 10.0 & 8.9 \\
\hline Intermediate & 0 & Oat & 3 & 39 & 7 & $<0.3$ & 2.0 & 2.0 \\
\hline Intermediate & 0 & Oat & 4 & 25 & 183 & 1.2 & 7.6 & 7.1 \\
\hline Intermediate & 0 & Ryegrass & 1 & 26 & 130 & 3.1 & 7.1 & 6.4 \\
\hline Intermediate & 0 & Ryegrass & 2 & 46 & 3 & $<0.3$ & 1.9 & 1.6 \\
\hline Intermediate & 0 & Ryegrass & 3 & 37 & 239 & 0.9 & 9.6 & 7.7 \\
\hline \multirow[t]{2}{*}{ Intermediate } & 0 & Ryegrass & 4 & 33 & 170 & 5.0 & 11.0 & 9.4 \\
\hline & & & Mean & & 111 & 2.6 & 7.5 & 6.3 \\
\hline Intermediate & 1 & Oat & 1 & 28 & 871 & 1.5 & 19.2 & 14.5 \\
\hline Intermediate & 1 & Oat & 2 & 29 & 28 & $<0.3$ & 12.9 & 8.6 \\
\hline Intermediate & 1 & Oat & 3 & 31 & 9 & $<0.3$ & 4.1 & 3.3 \\
\hline Intermediate & 1 & Oat & 4 & 44 & 4 & $<0.3$ & $<0.2$ & 1.0 \\
\hline Intermediate & 1 & Ryegrass & 1 & 27 & 219 & 2.0 & 13.8 & 10.3 \\
\hline Intermediate & 1 & Ryegrass & 2 & 42 & 2 & $<0.3$ & 1.0 & 1.2 \\
\hline Intermediate & 1 & Ryegrass & 3 & 45 & 136 & 1.1 & 16.0 & 10.3 \\
\hline \multirow[t]{2}{*}{ Intermediate } & 1 & Ryegrass & 4 & 35 & 4 & $<0.3$ & 1.4 & 1.7 \\
\hline & & & Mean & & 159 & 1.5 & 9.8 & 6.4 \\
\hline Intermediate & 2 & Oat & 1 & 30 & 26 & $<0.3$ & 8.3 & 5.8 \\
\hline Intermediate & 2 & Oat & 2 & 43 & 7 & $<0.3$ & $<0.2^{\dagger}$ & 1.0 \\
\hline Intermediate & 2 & Oat & 3 & 40 & 2 & $<0.3$ & $<0.2$ & 1.0 \\
\hline Intermediate & 2 & Oat & 4 & 34 & 13 & $<0.3$ & 2.1 & 2.3 \\
\hline Intermediate & 2 & Ryegrass & 1 & 48 & 1 & $<0.3$ & $<0.2$ & 1.1 \\
\hline Intermediate & 2 & Ryegrass & 2 & 36 & 366 & 1.8 & 7.7 & 5.1 \\
\hline Intermediate & 2 & Ryegrass & 3 & 38 & 16 & $<0.3$ & $<0.2$ & 1.3 \\
\hline \multirow[t]{2}{*}{ Intermediate } & 2 & Ryegrass & 4 & 47 & $<0.5^{\dagger}$ & $<0.3$ & 1.2 & $<0.2^{\dagger}$ \\
\hline & & & Mean & & 67 & 1.8 & 3.7 & 2.0 \\
\hline
\end{tabular}

† Detection Limit. 
TABLE A.13 Explosive Concentrations in Plot Soils for the High-TNT Area with Means by Organic Material Addition on 26 April 1994, 180 Days After Addition of Organic Material

\begin{tabular}{|c|c|c|c|c|c|c|c|c|}
\hline \multirow{2}{*}{$\begin{array}{l}\text { TNT } \\
\text { Level }\end{array}$} & \multirow{2}{*}{$\begin{array}{c}\text { Organic } \\
\text { Material } \\
\text { Addition (\%) }\end{array}$} & \multirow[b]{2}{*}{ Crop } & \multirow{2}{*}{$\begin{array}{c}\text { Replicate } \\
\text { Number }\end{array}$} & \multirow{2}{*}{$\begin{array}{c}\text { Plot } \\
\text { Number }\end{array}$} & \multicolumn{4}{|c|}{ Explosive Concentration (mg kg ${ }^{-1}$ ) } \\
\hline & & & & & TNT & TNB & 4A-DNT & 2A-DNT \\
\hline High & 0 & Oat & 1 & 9 & 344 & 1.3 & 10.6 & 11.8 \\
\hline High & 0 & Oat & 2 & 21 & 207 & 1.1 & 14.3 & 16.6 \\
\hline High & 0 & Oat & 3 & 2 & 258 & 1.2 & 7.3 & 8.5 \\
\hline High & 0 & Oat & 4 & 3 & 2290 & 4.6 & $<0.2^{\dagger}$ & $<0.2^{\dagger}$ \\
\hline High & 0 & Ryegrass & 1 & 18 & 1370 & 2.8 & 17.8 & 18.7 \\
\hline High & 0 & Ryegrass & 2 & 19 & 520 & 1.9 & 12.6 & 13.2 \\
\hline High & 0 & Ryegrass & 3 & 22 & 1110 & 2.2 & 1.6 & 15.4 \\
\hline \multirow[t]{2}{*}{ High } & 0 & Ryegrass & 4 & 13 & 1120 & 3.3 & 1.8 & 14.0 \\
\hline & & & Mean & & 902 & 2.3 & 9.4 & 14.0 \\
\hline High & 1 & Oat & 1 & 24 & 150 & 0.5 & 15.3 & 13.9 \\
\hline High & 1 & Oat & 2 & 11 & 1920 & 3.2 & 18.8 & 17.9 \\
\hline High & 1 & Oat & 3 & 23 & 1020 & 2.6 & 16.1 & 17.4 \\
\hline High & 1 & Oat & 4 & 17 & 2200 & 3.2 & 23.5 & 22.8 \\
\hline High & 1 & Ryegrass & 1 & 6 & 360 & 1.9 & 13.1 & 11.5 \\
\hline High & 1 & Ryegrass & 2 & 14 & 4060 & 5.1 & 1.7 & 4.2 \\
\hline High & 1 & Ryegrass & 3 & 15 & 6770 & 6.5 & $<0.2$ & $<0.2$ \\
\hline \multirow[t]{2}{*}{ High } & 1 & Ryegrass & 4 & 20 & 249 & 0.4 & 11.7 & 10.0 \\
\hline & . & & Mean & & 2091 & 2.9 & 14.3 & 14.0 \\
\hline High & 2 & Oat & 1 & 7 & 110 & $<0.3^{t}$ & 9.4 & 7.6 \\
\hline High & 2 & Oat & 2 & 1 & 334 & 1.5 & 22.7 & 17.1 \\
\hline High & 2 & Oat & 3 & 10 & 191 & 0.5 & 16.8 & 13.7 \\
\hline High & 2 & Oat & 4 & 8 & 1730 & 1.9 & 22.6 & 17.9 \\
\hline High & 2 & Ryegrass & 1 & 4 & 144 & 0.5 & 5.6 & 4.7 \\
\hline High & 2 & Ryegrass & 2 & 12 & 1720 & 2.4 & 26.4 & 20.4 \\
\hline High & 2 & Ryegrass & 3 & 16 & 2130 & 4.9 & $<0.2$ & $<0.2$ \\
\hline \multirow[t]{2}{*}{ High } & 2 & Ryegrass & 4 & 5 & 1020 & 5.8 & 14.4 & 15.3 \\
\hline & & & Mean & & 922 & 2.5 & 16.8 & 13.8 \\
\hline
\end{tabular}

t Detection Limit. 
TABLE A.14 Explosive Concentrations in Plot Soils for the Intermediate-TNT Area with Means by Organic Material Addition on 26 April 1994, 180 Days After Addition of Organic Material

\begin{tabular}{|c|c|c|c|c|c|c|c|c|}
\hline \multirow{2}{*}{$\begin{array}{l}\text { TNT } \\
\text { Level }\end{array}$} & \multirow{2}{*}{$\begin{array}{c}\text { Organic } \\
\text { Material } \\
\text { Addition (\%) }\end{array}$} & \multirow[b]{2}{*}{ Crop } & \multirow{2}{*}{$\begin{array}{c}\text { Replicate } \\
\text { Number }\end{array}$} & \multirow{2}{*}{$\begin{array}{c}\text { Plot } \\
\text { Number }\end{array}$} & \multicolumn{4}{|c|}{ Explosive Concentration (mg kg ${ }^{-1}$ ) } \\
\hline & & & & & TNT & TNB & 4A-DNT & 2A-DNT \\
\hline Intermediate & 0 & Oat & 1 & 41 & 83 & $<0.3^{\dagger}$ & 13.4 & 9.9 \\
\hline Intermediate & 0 & Oat & 2 & 32 & 24 & 0.4 & 6.7 & 6.0 \\
\hline Intermediate & 0 & Oat & 3 & 39 & 4 & $<0.3$ & 2.0 & 1.8 \\
\hline Intermediate & 0 & Oat & 4 & 25 & 1170 & 1.8 & $<0.2^{\dagger}$ & $<0.2^{\dagger}$ \\
\hline Intermediate & 0 & Ryegrass & 1 & 26 & 94 & 2.6 & 8.3 & 7.8 \\
\hline Intermediate & 0 & Ryegrass & 2 & 46 & 6 & $<0.3$ & 1.8 & 1.3 \\
\hline Intermediate & 0 & Ryegrass & 3 & 37 & 163 & 0.7 & 15.4 & 11.8 \\
\hline \multirow[t]{2}{*}{ Intermediate } & 0 & Ryegrass & 4 & 33 & 63 & 0.7 & 10.7 & 8.6 \\
\hline & & & Mean & & 201 & 1.2 & 8.3 & 6.7 \\
\hline Intermediate & 1 & Oat & 1 & 28 & 8480 & 10.5 & $<0.2$ & $<0.2$ \\
\hline Intermediate & 1 & Oat & 2 & 29 & 44 & $<0.3$ & 7.3 & 3.9 \\
\hline Intermediate & 1 & Oat & 3 & 31 & 14 & $<0.3$ & 2.2 & 2.0 \\
\hline Intermediate & 1 & Oat & 4 & 44 & 1 & $<0.3$ & 1.3 & 0.2 \\
\hline Intermediate & 1 & Ryegrass & 1 & 27 & 1230 & 6.6 & $<0.2$ & $<0.2$ \\
\hline Intermediate & 1 & Ryegrass & 2 & 42 & 2 & $<0.3$ & 1.2 & 1.4 \\
\hline Intermediate & 1 & Ryegrass & 3 & 45 & 69 & 1.4 & 12.2 & 6.2 \\
\hline \multirow[t]{2}{*}{ Intermediate } & 1 & Ryegrass & 4 & 35 & 2 & $<0.3$ & 0.8 & 1.4 \\
\hline & $\cdot$ & & Mean & & 1230 & 6.2 & 4.2 & 2.5 \\
\hline Intermediate & 2 & Oat & 1 & 30 & 7 & $<0.3$ & 3.7 & 3.0 \\
\hline Intermediate & 2 & Oat & 2 & 43 & $<0.5^{\dagger}$ & $<0.3$ & $<0.2$ & 1.0 \\
\hline Intermediate & 2 & Oat & 3 & 40 & 1 & $<0.3$ & 1.4 & 0.3 \\
\hline Intermediate & 2 & Oat & 4 & 34 & 4 & $<0.3$ & 2.6 & 1.9 \\
\hline Intermediate & 2 & Ryegrass & 1 & 48 & 7 & 0.3 & $<0.2$ & 1.0 \\
\hline Intermediate & 2 & Ryegrass & 2 & 36 & 5 & 0.4 & 1.7 & 1.8 \\
\hline Intermediate & 2 & Ryegrass & 3 & 38 & 10 & $<0.3$ & 0.9 & 1.2 \\
\hline \multirow[t]{2}{*}{ Intermediate } & 2 & Ayegrass & 4 & 47 & 1 & $<0.3$ & 1.1 & 0.2 \\
\hline & & & Mean & & 4 & 0.4 & 1.5 & 1.1 \\
\hline
\end{tabular}

†etection Limit. 
TABLE A.15 Explosive Concentrations in Plot Soils for the High-TNT Area with Means by Organic Material Addition on 7 June 1994, 222 Days After Addition of Organic Material

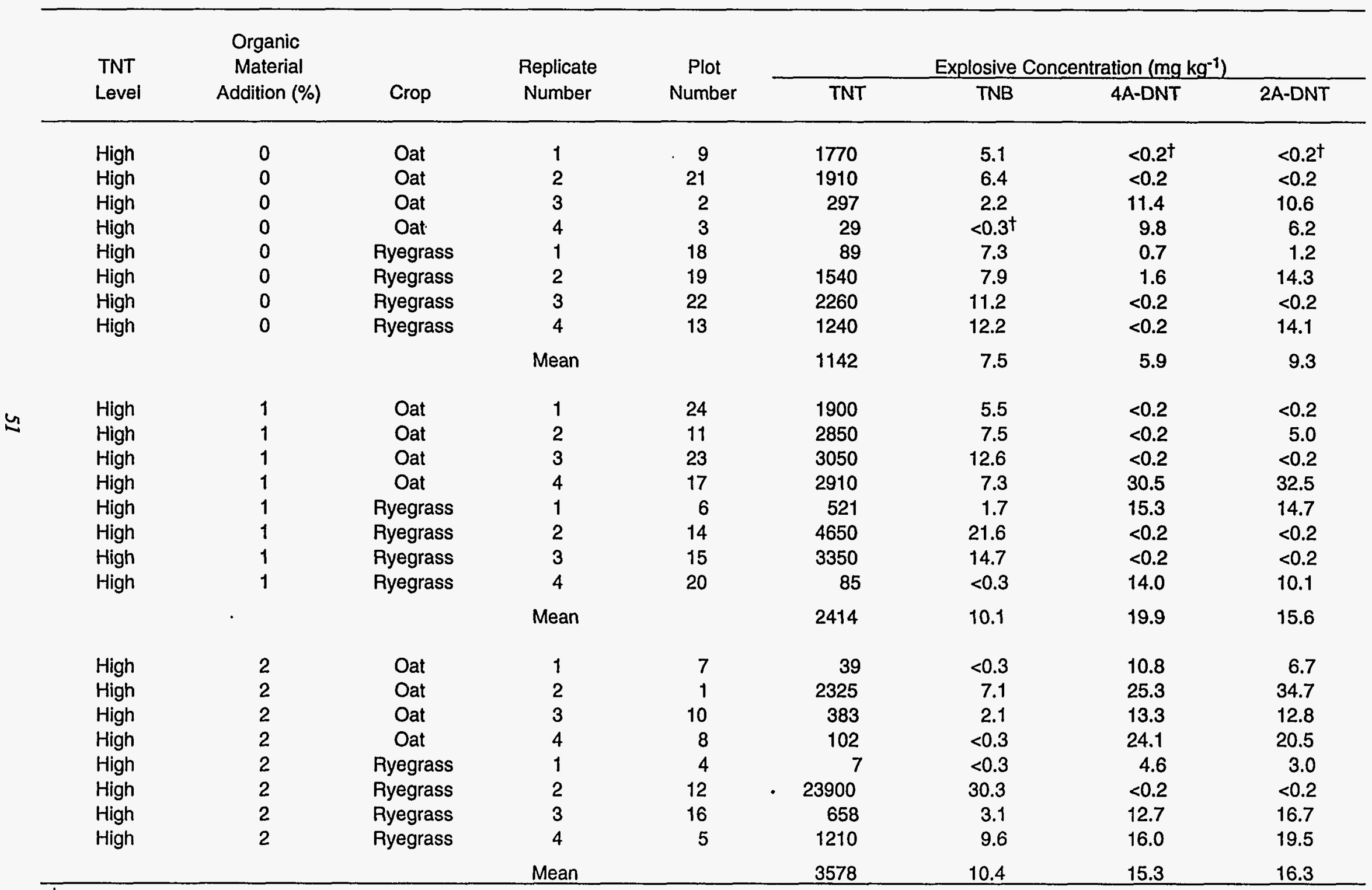

† Detection Limit. 
TABLE A.16 Explosive Concentrations in Plot Soils for the Intermediate-TNT Area with Means by Organic Material Addition on 7 June 1994, 222 Days After Addition of Organic Material

\begin{tabular}{|c|c|c|c|c|c|c|c|c|}
\hline \multirow{2}{*}{$\begin{array}{l}\text { TNT } \\
\text { Level }\end{array}$} & \multirow{2}{*}{$\begin{array}{c}\text { Organic } \\
\text { Material } \\
\text { Addition (\%) }\end{array}$} & \multirow[b]{2}{*}{ Crop } & \multirow{2}{*}{$\begin{array}{c}\text { Replicate } \\
\text { Number }\end{array}$} & \multirow{2}{*}{$\begin{array}{c}\text { Plot } \\
\text { Number }\end{array}$} & \multicolumn{4}{|c|}{ Explosive Concentration $\left(\mathrm{mg} \mathrm{kg}^{-1}\right)$} \\
\hline & & & & & TNT & TNB & 4A-DNT & 2A-DNT \\
\hline Intermediate & 0 & Oat & 1 & 41 & 32 & $<0.3^{\dagger}$ & 14.7 & 7.7 \\
\hline Intermediate & 0 & Oat & 2 & 32 & 25 & $<0.3$ & 5.8 & 2.0 \\
\hline Intermediate & 0 & Oat & 3 & 39 & 27 & $<0.3$ & 2.0 & 1.3 \\
\hline Intermediate & 0 & Oat & 4 & 25 & 56 & 1.5 & 7.0 & 5.4 \\
\hline Intermediate & 0 & Ryegrass & 1 & 26 & 297 & 5.6 & 5.7 & 4.4 \\
\hline Intermediate & 0 & Ryegrass & 2 & 46 & 3 & $<0.3$ & 1.1 & 1.1 \\
\hline Intermediate & 0 & Ryegrass & 3 & 37 & 101 & 2.2 & 16.9 & 10.1 \\
\hline \multirow[t]{2}{*}{ Intermediate } & 0 & Ryegrass & 4 & 33 & 162 & 1.6 & 8.6 & 5.9 \\
\hline & & & Mean & & 88 & 2.7 & 7.7 & 4.7 \\
\hline Intermediate & 1 & Oat & 1 & 28 & 962 & 24.7 & 0.9 & 12.3 \\
\hline Intermediate & 1 & Oat & 2 & 29 & 25 & $<0.3$ & 7.9 & 3.6 \\
\hline Intermediate & 1 & Oàt & 3 & 31 & 176 & $<0.3$ & 2.9 & $<0.2^{\dagger}$ \\
\hline Intermediate & 1 & Oat & 4 & 44 & 1 & $<0.3$ & 1.2 & 0.2 \\
\hline Intermediate & 1 & Ryegrass & 1 & 27 & 716 & 5.7 & $<0.2^{\dagger}$ & $<0.2$ \\
\hline Intermediate & 1 & Ryegrass & 2 & 42 & 1 & $<0.3$ & 0.6 & 1.1 \\
\hline Intermediate & 1 & Ryegrass & 3 & 45 & 69 & 1.9 & 8.6 & 3.1 \\
\hline \multirow[t]{2}{*}{ Intermediate } & 1 & Ryegrass & 4 & 35 & 1 & $<0.3$ & $<0.2$ & 1.0 \\
\hline & . & & Mean & & 244 & 10.8 & 3.7 & 3.6 \\
\hline Intermediate & 2 & Oat & 1 & 30 & 7 & 0.8 & 4.5 & 2.4 \\
\hline Intermediate & 2 & Oat & 2 & 43 & 6 & $<0.3$ & 0.2 & 1.0 \\
\hline Intermediate & 2 & Oat & 3 & 40 & 1 & $<0.3$ & 1.4 & 2.3 \\
\hline Intermediate & 2 & Oat & 4 & 34 & 27 & 1.2 & 5.3 & 3.3 \\
\hline Intermediate & 2 & Ryegrass & 1 & 48 & $<0.5^{\dagger}$ & $<0.3$ & 1.3 & $<0.2$ \\
\hline Intermediate & 2 & Ryegrass & 2 & 36 & 8 & $<0.3$ & 1.3 & $<0.2$ \\
\hline Intermediate & 2 & Ryegrass & 3 & 38 & 1 & $<0.3$ & $<0.2$ & 1.0 \\
\hline \multirow[t]{2}{*}{ Intermediate } & 2 & Ryegrass & 4 & 47 & $<0.5$ & $<0.3$ & 1.1 & $<0.2$ \\
\hline & & & Mean & & 8 & 1.2 & 1.8 & 1.9 \\
\hline
\end{tabular}

† Detection Limit. 
TABLE A.17 Explosive Concentrations in Plot Soils for the High-TNT Area with Means by Organic Material Addition on 19 July 1994, 264 Days After Addition of Organic Material

\begin{tabular}{|c|c|c|c|c|c|c|c|c|}
\hline \multirow{2}{*}{$\begin{array}{l}\text { TNT } \\
\text { Level }\end{array}$} & \multirow{2}{*}{$\begin{array}{c}\text { Organic } \\
\text { Material } \\
\text { Addition (\%) }\end{array}$} & \multirow[b]{2}{*}{ Crop } & \multirow{2}{*}{$\begin{array}{l}\text { Replicate } \\
\text { Number }\end{array}$} & \multirow{2}{*}{$\begin{array}{c}\text { Plot } \\
\text { Number }\end{array}$} & \multicolumn{4}{|c|}{ Explosive Concentration $\left(\mathrm{mg} \mathrm{kg}^{-1}\right)$} \\
\hline & & & & & TNT & TNB & 4A-DNT & 2A-DNT \\
\hline High & 0 & Oat & 1 & 9 & 129 & 1.4 & 11.1 & 9.7 \\
\hline High & 0 & Oat & 2 & 21 & 5650 & 13.2 & $<0.2^{\dagger}$ & $<0.2^{t}$ \\
\hline High & 0 & Oat & 3 & 2 & 890 & 7.0 & $<0.2$ & $<0.2$ \\
\hline High & 0 & Oat & 4 & 3 & 528 & 9.9 & $<0.2$ & $<0.2$ \\
\hline High & 0 & Ryegrass & 1 & 18 & 2120 & 12.6 & $<0.2$ & $<0.2$ \\
\hline High & 0 & Ryegrass & 2 & 19 & 810 & 10.8 & 12.2 & 11.9 \\
\hline High & 0 & Ryegrass & 3 & 22 & 7790 & 25.0 & $<0.2$ & $<0.2$ \\
\hline \multirow[t]{2}{*}{ High } & 0 & Ryegrass & 4 & 13 & 3700 & 21.5 & $<0.2$ & $<0.2$ \\
\hline & & & Mean & & 2702 & 12.7 & 11.7 & 10.8 \\
\hline High & 1 & Oat & 1 & 24 & 74 & 0.9 & 7.7 & 3.0 \\
\hline High & 1 & Oat & 2 & 11 & 1590 & 7.5 & $<0.2$ & $<0.2$ \\
\hline High & 1 & Oat & 3 & 23 & 1430 & 10.4 & $<0.2$ & $<0.2$ \\
\hline High & 1 & Oat & 4 & 17 & 2110 & 6.4 & $<0.2$ & $<0.2$ \\
\hline High & 1 & Ryegrass & 1 & 6 & 220 & 8.5 & 9.5 & 8.7 \\
\hline High & 1 & Ryegrass & 2 & 14 & 12600 & 21.4 & $<0.2$ & $<0.2$ \\
\hline High & 1 & Ryegrass & 3 & 15 & 2290 & 21.1 & $<0.2$ & $<0.2$ \\
\hline \multirow[t]{2}{*}{ High } & 1 & Ryegrass & 4 & 20 & 35 & $<0.3^{\dagger}$ & 9.2 & 4.1 \\
\hline & & & Mean & & 2544 & 10.9 & 8.8 & 5.3 \\
\hline High & 2 & Oat & 1 & 7 & 87 & $<0.3$ & 4.6 & 4.1 \\
\hline High & 2 & Oat & 2 & 1 & 134 & 4.1 & 13.5 & 13.1 \\
\hline High & 2 & Oat & 3 & 10 & 111 & 0.8 & 10.2 & 6.2 \\
\hline High & 2 & Oat & 4 & 8 & 259 & 1.3 & 18.1 & 15.7 \\
\hline High & 2 & Ryegrass & 1 & 4 & 27 & 0.3 & 2.4 & 2.4 \\
\hline High & 2 & Ryegrass & 2 & 12 & 897 & 8.5 & 25.6 & 17.4 \\
\hline High & 2 & Ryegrass & 3 & 16 & 569 & 6.4 & $<0.2$ & $<0.2$ \\
\hline \multirow[t]{2}{*}{ High } & 2 & Ryegrass & 4 & 5 & 2450 & 10.6 & $<0.2$ & $<0.2$ \\
\hline & & & Mean & & 567 & 4.6 & 12.4 & 9.8 \\
\hline
\end{tabular}


TABLE A.18 Explosive Concentrations in Plot Soils for the Intermediate-TNT Area with Means by Organic Material Addition on 19 July 1994, 264 Days After Addition of Organic Material

\begin{tabular}{|c|c|c|c|c|c|c|c|c|}
\hline \multirow{2}{*}{$\begin{array}{l}\text { TNT } \\
\text { Level }\end{array}$} & \multirow{2}{*}{$\begin{array}{c}\text { Organic } \\
\text { Material } \\
\text { Addition (\%) }\end{array}$} & \multirow[b]{2}{*}{ Crop } & \multirow{2}{*}{$\begin{array}{c}\text { Replicate } \\
\text { Number }\end{array}$} & \multirow{2}{*}{$\begin{array}{c}\text { Plot } \\
\text { Number }\end{array}$} & \multicolumn{4}{|c|}{ Explosive Concentration (mg kg-1) } \\
\hline & & & & & TNT & TNB & 4A-DNT & 2A-DNT \\
\hline Intermediate & 0 & Oat & 1 & 41 & 183 & 1.4 & 11.0 & 3.2 \\
\hline Intermediate & 0 & Oat & 2 & 32 & 4 & $<0.3^{\dagger}$ & 2.2 & 1.9 \\
\hline Intermediate & 0 & Oat & 3 & 39 & 5 & $<0.3$ & 0.8 & 1.8 \\
\hline Intermediate & 0 & Oat & 4 & 25 & 51 & 0.6 & 4.5 & 4.1 \\
\hline Intermediate & 0 & Ryegrass & 1 & 26 & 32 & 6.2 & 5.6 & 5.8 \\
\hline Intermediate & 0 & Ryegrass & 2 & 46 & 1 & $<0.3$ & $<0.2^{\dagger}$ & 1.9 \\
\hline Intermediate & 0 & Ryegrass & 3 & 37 & 80 & 1.5 & 12.9 & 8.2 \\
\hline \multirow[t]{2}{*}{ Intermediate } & 0 & Ryegrass & 4 & 33 & 27 & $<0.3$ & 8.9 & 6.0 \\
\hline & & & Mean & & 48 & 2.4 & 6.6 & 4.1 \\
\hline Intermediate & 1 & Oat & 1 & 28 & 2068 & 30.3 & $<0.2$ & $<0.2^{\dagger}$ \\
\hline Intermediate & 1 & Oat & 2 & 29 & 6 & $<0.3$ & 3.6 & 3.1 \\
\hline Intermediate & 1 & Oat & 3 & 31 & 4 & $<0.3$ & 1.0 & 2.1 \\
\hline Intermediate & 1 & Oat & 4 & 44 & 1 & $<0.3$ & $<0.2$ & 1.9 \\
\hline Intermediate & 1 & Ryegrass & 1 & 27 & 904 & 6.0 & $<0.2$ & $<0.2$ \\
\hline Intermediate & 1 & Ryegrass & 2 & 42 & $<0.5$ & $<0.3$ & $<0.2$ & 2.0 \\
\hline Intermediate & 1 & Ryegrass & 3 & 45 & 3 & 2.4 & 3.0 & 2.9 \\
\hline \multirow[t]{2}{*}{ Intermediate } & 1 & Ryegrass & 4 & 35 & 1 & $<0.3$ & $<0.2$ & 2.1 \\
\hline & . & & Mean & & 427 & 12.9 & 2.5 & 2.4 \\
\hline Intermediate & 2 & Oat & 1 & 30 & 104 & $<0.3$ & 2.2 & $<0.2$ \\
\hline Intermediate & 2 & Oat & 2 & 43 & 1 & $<0.3$ & $<0.2$ & 1.9 \\
\hline Intermediate & 2 & Oat & 3 & 40 & 1 & $<0.3$ & $<0.2$ & 1.9 \\
\hline Intermediate & 2 & Oat & 4 & 34 & 3 & $<0.3$ & 1.5 & 2.2 \\
\hline Intermediate & 2 & Ryegrass & 1 & 48 & 1 & $<0.3$ & $<0.2$ & 2.1 \\
\hline Intermediate & 2 & Ryegrass & 2 & 36 & 3 & $<0.3$ & 0.7 & 2.0 \\
\hline Intermediate & 2 & Ryegrass & 3 & 38 & 1 & $<0.3$ & $<0.2$ & 1.7 \\
\hline \multirow[t]{2}{*}{ Intermediate } & 2 & Ryegrass & 4 & 47 & $<0.5^{\dagger}$ & $<0.3$ & $<0.2$ & 1.8 \\
\hline & & & Mean & & 1 & $<0.3$ & 1.1 & 1.9 \\
\hline
\end{tabular}

† Detection Limit. 
TABLE A.19 Explosive Concentrations in Plot Soils for the High-TNT Area with Means by Organic Material Addition on 21 September 1994, 328 Days After Addition of Organic Material

\begin{tabular}{|c|c|c|c|c|c|c|c|c|}
\hline \multirow{2}{*}{$\begin{array}{l}\text { TNT } \\
\text { Level }\end{array}$} & \multirow{2}{*}{$\begin{array}{c}\text { Organic } \\
\text { Material } \\
\text { Addition (\%) }\end{array}$} & \multirow[b]{2}{*}{ Crop } & \multirow{2}{*}{$\begin{array}{l}\text { Replicate } \\
\text { Number }\end{array}$} & \multirow{2}{*}{$\begin{array}{c}\text { Plot } \\
\text { Number }\end{array}$} & \multicolumn{4}{|c|}{ Explosive Concentration (mg kg ${ }^{-1}$ ) } \\
\hline & & & & & TNT & TNB & 4A-DNT & 2A-DNT \\
\hline High & 0 & Oat & 1 & . 9 & 363 & 2.6 & 8.2 & 4.5 \\
\hline High & 0 & Oat & 2 & 21 & 67 & 1.5 & 9.2 & 4.9 \\
\hline High & 0 & Oat & 3 & 2 & 1950 & 3.8 & $<0.2^{\dagger}$ & $<0.2^{\dagger}$ \\
\hline High & 0 & Oat & 4 & 3 & 13 & 0.3 & 2.8 & 2.2 \\
\hline High & 0 & Ryegrass & 1 & 18 & 371 & 2.3 & 12.3 & 16.6 \\
\hline High & 0 & Ryegrass & 2 & 19 & 53 & 1.6 & 16.2 & 7.8 \\
\hline High & 0 & Ryegrass & 3 & 22 & 2370 & 5.8 & $<0.2$ & $<0.2$ \\
\hline \multirow[t]{2}{*}{ High } & 0 & Ryegrass & 4 & 13 & 624 & 5.7 & 10.1 & 13.0 \\
\hline & & & Mean & & 726 & 3.0 & 9.8 & 8.2 \\
\hline High & 1 & Oat & 1 & 24 & 527 & 1.7 & 5.9 & $<0.2$ \\
\hline High & 1 & Oat & 2 & 11 & 1300 & 5.8 & 11.5 & 0.5 \\
\hline High & 1 & Oat & 3 & 23 & 4510 & 11.0 & $<0.2$ & $<0.2$ \\
\hline High & 1 & Oat & 4 & 17 & 819 & 3.2 & 22.9 & 22.1 \\
\hline High & 1 & Ryegrass & 1 & 6 & 97 & 0.8 & 10.7 & 7.1 \\
\hline High & 1 & Ryegrass & 2 & 14 & 9150 & 18.3 & $<0.2$ & $<0.2$ \\
\hline High & 1 & Ryegrass & 3 & 15 & 3100 & 17.1 & $<0.2$ & $<0.2$ \\
\hline \multirow[t]{2}{*}{ High } & 1 & - Ryegrass & 4 & 20 & 74 & 1.1 & 9.9 & 3.5 \\
\hline & $\cdot$ & & Mean & & 2447 & 7.4 & 12.2 & 8.3 \\
\hline High & 2 & Oat & 1 & 7 & 102 & $<0.3^{\dagger}$ & 3.0 & 1.9 \\
\hline High & 2 & Oat & 2 & 1 & 44 & 0.7 & 16.7 & 12.2 \\
\hline High & 2 & Oat & 3 & 10 & 682 & 1.5 & 8.3 & $<0.2$ \\
\hline High & 2 & Oat & 4 & 8 & 167 & $<0.3$ & 12.7 & 5.9 \\
\hline High & 2 & Ryegrass & 1 & 4 & 18 & $<0.3$ & 1.6 & 1.4 \\
\hline High & 2 & Ryegrass & 2 & 12 & 1460 & 4.7 & 56.4 & 24.9 \\
\hline High & 2 & Ryegrass & 3 & 16 & 2380 & 14.1 & $<0.2$ & 2.4 \\
\hline \multirow[t]{2}{*}{ High } & 2 & Ryegrass & 4 & 5 & 351 & 4.1 & 9.8 & 6.9 \\
\hline & & & Mean & & 650 & 5.0 & 15.5 & 7.9 \\
\hline
\end{tabular}

† Detection Limit. 
TABLE A.20 Explosive Concentrations in Plot Soils for the Intermediate-TNT Area with Means by Organic Material Addition on 21 September 1994, 328 Days After Addition of Organic Material

\begin{tabular}{|c|c|c|c|c|c|c|c|c|}
\hline \multirow{2}{*}{$\begin{array}{l}\text { TNT } \\
\text { Level }\end{array}$} & \multirow{2}{*}{$\begin{array}{c}\text { Organic } \\
\text { Material } \\
\text { Addition (\%) }\end{array}$} & \multirow[b]{2}{*}{ Crop } & \multirow{2}{*}{$\begin{array}{c}\text { Replicate } \\
\text { Number }\end{array}$} & \multirow{2}{*}{$\begin{array}{c}\text { Plot } \\
\text { Number }\end{array}$} & \multicolumn{4}{|c|}{ Explosive Concentration $\left(\mathrm{mg} \mathrm{kg}^{-1}\right)$} \\
\hline & & & & & TNT & TNB & 4A-DNT & 2A-DNT \\
\hline Intermediate & 0 & Oat & 1 & 41 & 21 & $<0.3^{\dagger}$ & 8.4 & 4.1 \\
\hline Intermediate & 0 & Oat & 2 & 32 & 2.2 & $<0.3$ & 1.8 & $<0.2^{\dagger}$ \\
\hline Intermediate & 0 & Oat & 3 & 39 & 0.7 & $<0.3$ & 0.5 & 0.9 \\
\hline Intermediate & 0 & Oat & 4 & 25 & 916 & 5.1 & $<0.2^{\dagger}$ & $<0.2$ \\
\hline Intermediate & 0 & Ryegrass & 1 & 26 & 426 & 10.2 & 0.8 & $<0.2$ \\
\hline Intermediate & 0 & Ryegrass & 2 & 46 & $<0.5^{\dagger}$ & $<0.3$ & $<0.2$ & 1.0 \\
\hline Intermediate & 0 & Ryegrass & 3 & 37 & 17 & $<0.3$ & 8.4 & 2.4 \\
\hline \multirow[t]{2}{*}{ Intermediate } & 0 & Ryegrass & 4 & 33 & 34 & 0.8 & 6.5 & 3.2 \\
\hline & & & Mean & & 202 & 5.4 & 4.4 & 2.3 \\
\hline Intermediate & 1 & Oat & 1 & 28 & 2570 & 15.6 & $<0.2$ & $<0.2$ \\
\hline Intermediate & 1 & Oat & 2 & 29 & 11 & $<0.3$ & 1.4 & 1.8 \\
\hline Intermediate & 1 & Oat & 3 & 31 & 13 & $<0.3$ & 0.6 & 1.0 \\
\hline Intermediate & 1 & Oat & 4 & 44 & 0.7 & $<0.3$ & $<0.2$ & 0.8 \\
\hline Intermediate & 1 & Ryegrass & 1 & 27 & 29 & $<0.3$ & 1.9 & 0.6 \\
\hline Intermediate & 1 & Ryegrass & 2 & 42 & 0.4 & $<0.3$ & 0.3 & 0.8 \\
\hline Intermediate & 1 & Ryegrass & 3 & 45 & 953 & 0.8 & $<0.2$ & $<0.2$ \\
\hline \multirow[t]{2}{*}{ Intermediate } & 1 & Ryegrass & 4 & 35 & 0.5 & $<0.3$ & 0.3 & 1.0 \\
\hline & . & & Mean & & 447 & 8.2 & 0.9 & 1.0 \\
\hline Intermediate & 2 & Oat & 1 & 30 & 3.9 & $<0.3$ & 1.6 & 0.9 \\
\hline Intermediate & 2 & Oat & 2 & 43 & 0.8 & $<0.3$ & $<0.2$ & 0.8 \\
\hline Intermediate & 2 & Oat & 3 & 40 & 0.4 & $<0.3$ & $<0.2$ & 0.8 \\
\hline Intermediate & 2 & Oat & 4 & 34 & 12 & 0.8 & 1.5 & 1.9 \\
\hline Intermediate & 2 & Ryegrass & 1 & 48 & $<0.5$ & $<0.3$ & $<0.2$ & 0.7 \\
\hline Intermediate & 2 & Ryegrass & 2 & 36 & 1.1 & $<0.3$ & 0.6 & 1.0 \\
\hline Intermediate & 2 & Ryegrass & 3 & 38 & 0.4 & $<0.3$ & 0.3 & 0.9 \\
\hline \multirow[t]{2}{*}{ Intermediate } & 2 & Ryegrass & 4 & 47 & $<0.5$ & $<0.3$ & $<0.2$ & 0.7 \\
\hline & & & Mean & & 2.9 & 0.8 & 0.8 & 1.0 \\
\hline
\end{tabular}

\footnotetext{
† Detection Limit.
} 